\title{
Exports of Nordic Used Textiles
}

Fate, benefits and impacts 



\section{Exports of Nordic Used Textiles}

Fate, benefits and impacts

David Watson, David Palm, Louise Brix, Maria Amstrup,

Frode Syversen and Rasmus Nielsen

TemaNord 2016:558 


\section{Exports of Nordic Used Textiles}

Fate, benefits and impacts

David Watson, David Palm, Louise Brix, Maria Amstrup, Frode Syversen and Rasmus Nielsen

ISBN 978-92-893-4769-3 (PRINT)

ISBN 978-92-893-4770-9 (PDF)

ISBN 978-92-893-4771-6 (EPUB)

http://dx.doi.org/10.6027/TN2016-558

TemaNord 2016:558

ISSN $0908-6692$

Standard: PDF/UA-1

ISO 14289-1

(c) Nordic Council of Ministers 2016

Layout: Hanne Lebech

Cover photo: Scanpix

Print: Rosendahls-Schultz Grafisk

Printed in Denmark

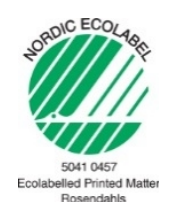

Although the Nordic Council of Ministers funded this publication, the contents do not necessarily reflect its views, policies or recommendations.

\section{Nordic co-operation}

Nordic co-operation is one of the world's most extensive forms of regional collaboration, involving Denmark, Finland, Iceland, Norway, Sweden, the Faroe Islands, Greenland, and Åland.

Nordic co-operation has firm traditions in politics, the economy, and culture. It plays an important role in European and international collaboration, and aims at creating a strong Nordic community in a strong Europe.

Nordic co-operation seeks to safeguard Nordic and regional interests and principles in the global community. Shared Nordic values help the region solidify its position as one of the world's most innovative and competitive. 


\section{Contents}

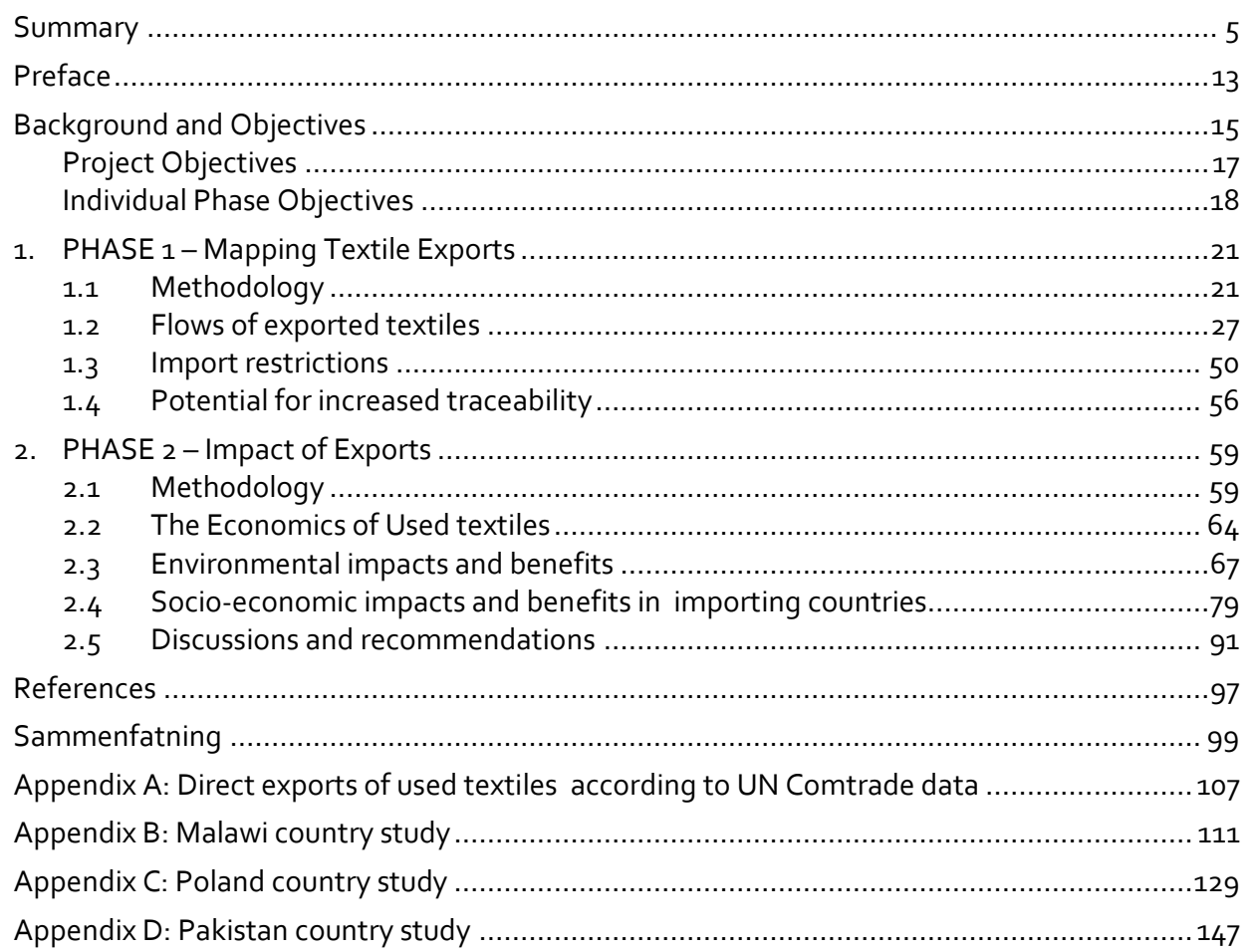





\title{
Summary
}

\author{
Background and aim
}

Reducing the environmental impacts of textiles is a key issue for the Nordic Council of Ministers under its Green Growth program. Amongst other issues efforts have focused on stimulating the collection, reuse and recycling of used textiles.

Separate collection rates of used textiles vary from $22 \%$ in Sweden to $46 \%$ in Denmark with the majority of the remainder ending in mixed waste streams for incineration. Used textiles collection is predominantly carried out by charities to generate income to fund charitable activities. A large proportion of the collected textiles are sold on the global market.

Knowledge on quantities, final destination countries and the fate of Nordic textiles once they arrive is very limited. There is also a lack of information on whether the net social, economic and environmental impacts of this export are positive or negative.

This project aimed to map out exports of used textiles from Nordic countries and to estimate the potential socio-, economic- and environmental impacts, benefits and risks of these textiles in destination countries.

\section{Pathways of exported textiles}

Exports of used textiles from four Nordic countries (Denmark, Finland, Norway and Sweden) were mapped out using statistical databases that provide information on first destinations, and via interviews with the 13 biggest Nordic exporters, giving information on onward paths.

According to the statistical data, exports of worn Nordic textiles increased from 60,000 tonnes in 2011 to 75,000 tonnes in 2014. In addition, around 2,800 tonnes of rags were exported. First destinations for used textiles number at least 115 countries. $82 \%$ of exports are to 10 individual countries, all but one of which (Turkey) lie within the EU.

Many of the importers of Nordic textiles receive considerable quantities from elsewhere. However, the Nordic export represents a significant share of imports to Estonia, Somalia, Poland, Lithuania and Bulgaria. 
Interviews with collectors gave insight into what happens to textiles after their arrival at first destinations; information that can't be obtained from statistics. Together the 13 interviewed collectors reported having exported just over 70,000 tonnes of textiles from the Nordic countries in 2014. The majority are sold to wholesalers or second-hand sorters and retailers to raise money for charitable activities. Donations of textiles as aid or crisis relief is very limited. Collectors increasingly require their buyers to adopt codes of conduct concerning working conditions for employees. Fewer have requirements or receive regular reports on the eventual fate of the textiles.

A quarter of the textiles exported by the 13 collectors have been pre-sorted in the Nordic countries, to remove the $10 \%$ highest quality for sale in Nordic countries and to remove textile and non-textile waste. The pre-sorted textiles are predominantly exported within Europe but also further afield.

The remaining three-quarters of exported textiles are unsorted ("original") apart from superficial removal of non-textile waste. Original is almost exclusively exported to EU countries for sorting, mostly in Eastern Europe.

Following sorting the textile fractions are sold on the domestic market or reexported for sale on the global market. Eastern Europe is an important final destination for Nordic textiles, but non-European countries are also important. At least 7,500 tonnes, or $11 \%$ of all the exported Nordic textiles end in India and Pakistan, while 12,000 tonnes (18\%) end in the African continent.

Where waste (either textile or non-textile) is mixed in with used textiles exported from the Nordic countries, this either remains in Europe in the sorting country, where it is treated responsibly, or is exported to Eastern Asia - primarily India and Pakistan - for mechanical recycling. Very little textile waste is found in exports to African countries.

\section{A dynamic market}

Deeper studies were carried out in three sample countries - Poland, Malawi and Pakistan - to investigate what happens at various point along the value chain and to give a picture of the global effects of the trade.

The reuse and recycling of textiles can be described as a cascade in quality and value that spreads from rich countries out to poorer ones. The top $10 \%$ quality of discarded textiles in the Nordic countries can be sold for reuse domestically but the remainder must find markets where populations are less wealthy. The better quality textiles remain in Europe, primarily in the east including Russia. Tropical mix and lower quality textiles are exported to Africa, the Middle East and Central Asia. 
The end destinations are under constant development as economies progress. Lower grade textiles that ten years ago could have been sold for reuse in Poland are no longer in demand. New markets have been found further afield in Eastern Europe, the Middle East or Asia.

In recent years the market has been characterised by a glut of discarded textiles collected in US, Europe and elsewhere, chasing a dwindling demand as economic growth increases incomes abroad. This has led to reduced prices on global markets.

\section{Tight margins lead to efficient use}

Reduced prices increase the share of used textiles that are reused and recycled. Buyers of original are forced to find a market for every single fraction that they contain in order to be able to pay for sorting operations.

No longer can they make ends meet by just selling the cream and the better grades of reusable textiles. They also have to sell second grade textiles, rags for mechanical recycling and plastic bags for plastic recycling despite the very low price for these fractions. The full value of the exported used Nordic textiles is thus utilised as far as possible.

Since reuse yields a higher price than recycling, and recycling yields higher prices than other waste treatments, economic signals also ensure that the waste hierarchy is met. In other words tight margins ensure that most environmental gain is raised from exported Nordic textiles.

\section{Significant global environmental benefits}

Annual Nordic exports of 75,000 tonnes of used textiles are estimated to give an annual net saving of 193,000 tonnes $\mathrm{CO}^{2}$ equiv of greenhouse gases and 72 million cubic metres of water use, and a host of other environmental benefits.

The benefits arise because the impacts caused by the transportation and processing of used textiles were found to be small in comparison to the savings caused by offset new textile production. This is despite conservative estimates for the degree to which sales of used textiles offset production of new textiles.

The benefits are far higher than would have been achieved if the textiles had remained in Nordic countries. In this case the most likely fate would be incineration; domestic markets currently don't exist to reuse or recycle 75,000 tonnes of additional used textiles. 


\section{Local environmental impacts}

The concern that the export market leads to export of waste to countries that are less able to deal with it was not substantiated.

Almost all non-reusable/non-recyclable textile and non-textile waste is removed at sorting facilities in EU Member States in Eastern Europe prior to export to the rest of the world. Since the majority of waste treatment facilities in EU Member States in Eastern Europe now comply with EU minimum standards the waste is treated responsibly especially as narrow margins encourage sorters to sell as many fractions as possible for recycling.

The narrow margins also mean that nearly all textiles exported to developing countries are reused or recycled. We weren't able, however, to gain data on the environmental profile of recycling facilities in Asia.

Imported Nordic textiles for second hand markets may lead indirectly to local environmental impacts in Africa and Asia once the local consumers have worn them out. This is due to low municipal waste collection rates particularly in rural areas, and unsatisfactory waste treatment of the fraction that is collected. This is also true of imports of new textiles. Little information is available on what happens to clothing in developing countries when it no longer can be repaired.

\section{Job creation}

The export of Nordic used textiles is estimated to lead to the creation of approximately 1,500 full time equivalent jobs in sorting, 2,000 in wholesale and 5,500 in the regulated retail sector in receiving countries.

The numbers of families supported in the informal sector in developing countries could be even higher. The approximately 12,000 tonnes of Nordic textiles exported to the African continent alone, are estimated to support more than 10,000 market sellers and their families.

If the trade in used textiles offsets the trade and manufacture of new textiles in the receiving countries, net employment generated by Nordic exports may be somewhat lower than this. 


\section{The potential of codes of conduct}

The same tight economic margins that ensure that all fractions of used textiles are put to good use, can also drive owners of sorting facilities to pay low wages and cut corners in health and safety.

Increased traceability and codes of conduct imposed by Nordic collectors on their buyers downstream, could be a potential solution. In order for CoCs to have an effect, implementation must be regularly monitored and enforced. Where such CoCs are in place, working conditions and health and safety standards are being upheld. CoCs have more limited potential to influence working conditions in the informal sector, however.

Although economics currently ensure that reuse and recycling are prioritised, CoCs may also become important tools in ensuring that the waste hierarchy is adhered to, should economic conditions change.

\section{Impacts on domestic textile industry}

Used textiles from Europe and other developed countries represent an important source of clothing for a significant part of populations in sub-Saharan Africa. More than half, by value, of imported textiles to Kenya, Ghana, Rwanda, Uganda, Tanzania and Malawi are used textiles. The share measured by weight is probably much higher.

Used imports provide cheap and good quality clothing for those who otherwise may not be able to afford it. On the other hand, these imports may also have contributed to the decline of the domestic textile industry in these and other sub-Saharan countries.

The decline of the domestic industry may have happened even in the absence of the second hand sector. There is evidence that ageing and inefficient domestic industries have been unable to compete with production in Asia as trade barriers were removed during the late 1990 s and early 2000s. Both used and new textile imports have increased rapidly since at least 2000 across sub-Saharan Africa. There is no evidence that in the absence of used textile the gap would not have been filled by additional imports of cheap new textiles from Asia. 


\section{Import restrictions}

Parts of sub-Saharan African, along with countries in other parts of the world inhibit imports of used textiles via bans, restrictions or prohibitively high taxes.

Such restrictions may be a sticking plaster rather than a real solution to the decline in local industries. The ban in South Africa has not stemmed the decline in the domestic industry. Imports of new clothes to South Africa per capita are ten times higher in value than total imports of new and used to the other mentioned countries and growing rapidly.

Bans and restrictions on used textiles can also have negative side effects. Trade can shift to illegal pathways leading to an associated loss of revenue in the form of import duties. They can also damage what many governments have appreciated as an important poverty-reducing activity; it is relatively easy to start-up as a market trader in second-hand clothing and the sector in sub-Saharan Africa and elsewhere has pulled tens of thousands of families out of poverty.

The impact on domestic textile industries could instead be reduced by focusing on production for the export market, by specialising in particular types of textiles and by investing in modern equipment and processes to allow the industry to compete on global markets. This will require significant investments that, in developing countries, may need to be attracted from elsewhere.

\section{Recommendations}

\section{Recommendations for Nordic collectors/exporters of used textiles:}

- Adapt or adopt a Code of Conduct for own operations and for downstream operators with emphasis on:

- Working conditions, wages and health and safety.

- Goals for reuse and recycling shares and treatment options for remaining waste.

- Effective and regular monitoring, reporting and follow-up.

- Assist, as far as possible, your existing buyers to meet your requirements rather than switching buyers as soon as there is non-compliance.

- Where possible prioritise buyers with their own retail shops rather than wholesalers to improve or simplify traceability. 
- Where possible nurture long-term relationships with buyers to ensure that exports are matched to needs and waste is avoided.

- Remove obvious textile and non-textile waste from original prior to export.

- Prioritise EU countries for sorting of exported textiles.

- Investigate opportunities to support better collection and treatment of postconsumer textiles in developing countries.

- Engage in projects with the aim of increasing reuse and recycling within Nordic markets.

Recommendations for Nordic policy-makers

- Develop guidelines for collectors and exporters on interpretation of national, European and international regulations on the transport of used textiles.

- Assist in the further development of, and encourage the adoption by collectors of the Nordic Council of Ministers pilot Code of Conduct.

- Assist developing countries in improving systems for collection and treatment of household waste.

- Establish strategies, seeding projects, innovation funding pools etc. to encouraging stronger markets for reuse and recycling of textiles in Nordic markets, though without compromising the waste hierarchy.

- Continue and increase support for increased collection of used textiles both for the Nordic and export markets. 



\section{Preface}

The project was carried out in the period from September 2015 to September 2016. The project group was composed of experts from five organisation in three Nordic countries:

- David Watson, PlanMIljø, DK.

- David Palm, Ramböll, SE.

- Louise Brix and Maria Amstrup, Rambøll Management, DK.

- Frode Syversen, Mepex, NO.

- Rasmus Nielsen, FORCE Technology, DK.

David Watson, PlanMiljø was the project manager and team leader. The work was initiated, funded by NWG (the Nordic Waste Group) of the Nordic Council of Ministers, with Yvonne Augustsson from Naturvårdsverket, Sweden, as the main contact point.

The project group wishes to thank representatives from 13 Nordic collectors and exporters of used textiles for their time and input to the project without whom this project would have been impossible. 



\section{Background and Objectives}

The Nordic Environmental Action Programme 2013-18 includes the aim that the Nordic region's global footprint should be reduced. The consumption of textiles has been shown by various studies to be the most impacting European consumption area after mobility, food and housing (EEA, 2013; JRC, 2014; Tukker et al. 2006 etc.). Nordic consumption of textiles is relatively high by European standards; Danish, Swedish, Norwegian and Finnish citizens consume between 13 and $16 \mathrm{~kg}$ of new textiles each year (Tojo et al., 2012; Palm et al., 2014).

Over the last few years reducing the environmental impacts of textiles has been a key issue for the Nordic Council of Ministers, with focus on the post-use phase. The Prime Minister's Green Growth Initiative and the recently adopted Nordic Action Plan for Sustainable Fashion and Textiles includes objectives to increase the collection, reuse and recycling of used textiles in the Nordic countries in order to reduce impacts associated with the Nordic consumption of textiles.

Under one of three Green Growth textiles projects initiated in 2013, a mapping of textile flows in Nordic countries was carried out (Palm et al., 2014). Estimated separate collection rates of textiles following use were found to vary from $22 \%$ in Sweden to $46 \%$ in Denmark with the majority of the remainder ending in mixed waste streams bound for incineration plants.

The project went on to develop scenarios for how collection rates and subsequent reuse and recycling rates could be increased. Increased collection, reuse and recycling should in general have positive environmental benefits compared to incineration, though the advantages are far more significant for reuse than recycling (Schmidt et al., in press).

The majority of separate used textiles collection in Nordic countries is carried out by charities, although some private operators are also active. Textiles are primarily collected to develop income for charities to fund their charitable activities and textiles are sold on the global market where the highest price can be gained. Models for organisations vary. Some sort part or all of collected textiles domestically, separate off a portion for resale in Nordic countries (typically 10-20\%), and export the majority of the remainder for further sorting, reuse and recycling elsewhere. Other organisations export collected textiles unsorted for sorting in other countries. In general the export of used textiles have increased significantly over the past decade (Watson et al., 2014). 
There is information available from charitable organisations that textiles are typically exported to the Balkans, Eastern Europe and Africa, but that some also find their way to Asia for recycling following sorting. However, knowledge on quantities, final destination countries and the fate of textiles once they arrive is very limited within the Nordic Council of Ministers and the Nordic governments. This information and knowledge on whether the net social, economic and environmental impacts of this export are positive or negative is needed.

This question has been raised for some time in other western countries and both positive and negative stories can be found. With respect to social and economic impacts, Andrew Brooks from University College, London has found evidence from subSaharan Africa that imports of cheap used clothing from western countries negatively affected local textiles production during past decades (Brooks, 2015).

Brooks however also proposes that while cheap imports of second-hand clothes were devastating for the Malawian textile industry, the decline in the clothing industry across most of the continent was due to a complex set of conditions, central to which was economic liberalisation. One result of this was an increasing import of cheap new textiles from Asia combined with a simultaneous privatisation of state-owned textiles factories in Africa which could not compete on an open market (Brooks, 2012). Pietra (2014) agrees with this picture of a more complex set of causes. He goes on to say that producing for export rather than domestic production is perhaps more effective development and such an export industry would not be impacted by imports of cheap second-hand clothing from the west.

Nevertheless, apparently responding to risks, real or not, to the local textile industry, several countries have imposed various types of import restrictions on used textiles while other countries are considering such restrictions (e.g. Tanzania, Kenya, Uganda, Rwanda, Burundi) (Politiken, 2015).

There are also examples of positive local socio-economic impacts, particularly where charities have directly had the goal of providing local jobs via their supply of used textiles. Oxfam UK, for example, has reported on employment creation in receiving countries and how the imports also provide lower-cost clothing for people living in poverty (Baden \& Barber, 2015). Pietra (2014) identified large numbers of jobs that had been created in Tanzania around preparing second-hand imports for resale.

With respect to environmental impacts, the import of used textiles, while having the potential to give net global environmental benefits can also be responsible for negative local impacts. An example would be where unsorted textiles are sent to a country with poor waste management systems. The fraction of textiles not fit for reuse might end in a 
badly managed landfill or worse discarded in open fly-tips. ${ }^{1}$ This was confirmed as an occurrence in Iraq by one of the interviewees for this report whom now is working hard with reducing waste in the flows for the Iraq market. Whether these impacts would offset the global environmental benefits of the reused fraction is unclear.

The Nordic Textile Reuse and Recycling Commitment and associated Code of Conduct currently being piloted for used textile collectors, provides a potential tool for reducing negative impacts while increasing positive impacts. This can take place, for example, by including criteria for organisations on where collected textiles are sent to and how they are managed (Elander et al., 2015). The current criteria set demands for reuse and recycling at the "first end-user of used textiles" but the possible levels of additional traceability are being investigated in the current trial of the Code of Conduct, which will end in September 2016.

Before this or other leverage points can be investigated or proposed, knowledge on the pathways, fate and impacts of exported Nordic used textiles needs to be improved.

\section{Project Objectives}

The broad aim of the project is to increase knowledge about the fate of used textiles collected in Nordic countries and subsequently exported. This will provide a basis for adjusting as necessary Nordic policy aimed at increasing the sustainability of textiles, so that it is also sustainable in an international perspective.

The project aims to answer the following questions:

- What are the flows of used textiles from the Nordic region?

- How large are the environmental consequences of exported used textiles and textile waste from the Nordic region, seen from an international perspective?

- Is the export of used textiles currently economically, socially and environmentally sustainable?

\footnotetext{
${ }^{1}$ Flytipping is the illegal dumping of waste in non-registered sites; typically by the roadside or in forests or other natural areas.
} 
- What is the risk that by increasing the separate collection of discarded textiles in Nordic countries we are causing environmental problems in countries with weaker regulations and available resources to take care of used textiles in an environmentally sustainable way?

The final output of the project is a set of policy recommendations for Nordic governments and collection/export organisations to ensure that the export of Nordic used textiles is sustainable. These are to take into account existing NCM activities concerning traceability and codes of conduct in the treatment of used textiles (the Nordic Textile Commitment).

\section{Individual Phase Objectives}

The project was carried out in two distinct phases with their own sub-goals. The aim of the first phase was to carry out a mapping of flows of used textiles exported from Nordic countries to their final destinations. This phase aimed to answer the following questions:

- What are the pathways and quantities of used textiles exported from Nordic countries, which organisations are involved in these pathways and which are the receiving regions and countries?

- To what extent are flows captured in export statistics in Nordic countries? Which flows are not captured in these statistics?

- How do flows for different broad product types (clothes, household textiles) and fibre types (cotton, polyester, wool) and other textiles properties differ?

- Which regions and countries import the largest volumes of used textiles from Nordic countries? Which countries restrict imports of used textiles or are developing import restrictions and why?

The second phase comprised a deeper investigation into the fate of used textiles in three selected countries, and an analysis of likely socio-, economic- and environmental impacts, benefits and risks. The country studies aimed to answer the following questions:

- How are used textiles imported to the three recipient countries subsequently treated? What share is reused and what share directly becomes waste and how is this waste treated? 
- What are the likely consequences (positive and negative), of imports of used textiles and textile waste on the environment, health and economy of the three recipient countries? What is the impact on the local textile industry and employment in the beneficiary countries?

- What is the purpose of import restrictions in countries? Have import restrictions already in place had the desired effect? 



\section{PHASE 1 - Mapping Textile Exports}

\subsection{Methodology}

Mapping of textiles flows has already been carried out under a number of previous projects for the Nordic Council of Ministers and for individual countries (Tojo et al., 2012; Palm et al., 2014; Watson et al., 2014, Elander et al. 2014). Under those projects, flows of used textiles within Nordic countries were mapped using both data from national statistics offices and from direct contact with collecting organisations, waste authorities etc. The studies include estimations and calculations of exports of used textiles from the Nordic countries but did not investigate in any depth the end destination for these textiles.

Under Phase 1 of this project we have mapped out flows using both existing statistical information and via survey of key Nordic collectors of used textiles. The results under this phase have also been updated where appropriate by data collected under Phase 2.

For this project, due to limited budget, we decided to concentrate on exports from the four largest Nordic countries: Denmark, Finland, Norway and Sweden with correspondingly, the largest exports of used textiles.

Textiles exported from Iceland and the semiautonomous regions of Greenland, the Faroe Islands and the Åland Islands are not covered by the data and surveys in this report.

Before discussing the two main methods we have used for collecting and analysing flows of used textiles out of these four Nordic countries we present a short note on definitions and characterisations of used textiles.

\subsubsection{A short note on definitions}

Used textiles and textiles waste:

In this report unsorted used textiles donated to charities and other collection organisations are not considered as textiles waste since they have potential for reuse in their 
original function. ${ }^{2}$ Here we call these "used textiles" up until the point of detailed sorting, domestically or in other countries. Following sorting those fractions of the textiles which are not considered suitable for reuse are defined as waste. These can be recycled, downcycled, incinerated, landfilled or otherwise. Under EU regulations unsorted original should be considered as waste up to the point of sorting, and should be registered as green-coded waste when transported across borders.

\section{Reuse and recycling:}

Under the waste hierarchy, reuse means the reuse of the product in its original form and for the original purpose without any (major) processing underway. Small repairs are not considered as major processing. Recycling when used in this report, covers all forms of material recovery. This can for example be mechanical or chemical recycling back into textile fibres, processing into industrial rags, upholstery fill, insulation and so on. Where the final product has a lower quality than the original product the process this can also be termed downcycling.

We have tried to ensure during interviews that the interviewees have the same understanding of reuse and recycling when answering questions.

Product codes for used textiles:

As is described in more detail under 1.2 .2 below, used textiles are generally separated into two main product codes under the $\mathrm{CN}$-product code system: 6309 worn textiles and clothing; and 6310 sorted and unsorted used rags and textile scraps. In general code 6309 should be given to textiles fit for reuse, while 6310 should be given to textiles which aren't fit for reuse and may or may not already have been processed into other products like industrial rags.

However, as will be seen later, a major part of exported used textiles are exported in unsorted form (so-called "original") and are likely to contain textiles fit for and unfit for reuse. Discussions with collectors have demonstrated that unsorted textiles (or "original" as they are known in the branch) are, nevertheless, typically recorded under code 6309. There are some exceptions from this rule. There are suggestions that the German authorities increasingly categorise original as rags under 6310, in part as a result of their more strict waste shipment approaches with respect to textiles (see below) (see Poland country report).

\footnotetext{
${ }^{2}$ The Waste Framework Directive (WFD) (2006/12/EC) states that "'waste' shall mean any substance or object...which the holder discards or intends or is required to discard." This means textiles destined for reuse in the same purpose are not waste.(Morley et al., 2009).
} 
Product codes and shipments of waste:

Textiles appear on the European Waste List, and it is up to the competent authorities in each of the EU countries to decide whether textiles are intended for reuse in their original form, or whether they should fall under the EU Waste Shipment Regulations (Morley et al., 2009) and/or controlled waste under the Basel Convention. As a rule of thumb textiles under 6309 are likely to be considered as non-waste while 6310 might be considered as waste. However, this may vary from authority to authority. Unsorted textiles also present a challenge for such categorization. Clothing and textiles exported as non-waste from one country may be deemed waste by the importing country leading to legal complications. Some individual cases were identified during interviews of where this had occurred.

Where exports of used textiles are considered as waste under the Waste Shipment Regulations, for the most part these will be considered as "Green Code" waste i.e. the lowest level of control since the risk of hazardous contents is considered low. Green control procedures apply to textiles (including rags) that are not soiled with other waste, including if they are mixed with shoes and/or leather goods. Where there is considered to be risk of contamination by hazardous waste such as electronic waste the control procedures are more stringent (Swiss Federal Office for the Environment, 2016).

Germany is particularly stringent with respect to shipments of textiles, classifying all shipments of original, even pre-sorted to remove large pieces of non-textile waste, as hazardous under the Basel Convention. This means that drivers need to be registered drivers of hazardous waste and there are additional registration procedures for these shipments (see Appendix C). This particularly affects transport of used textiles from Denmark.

\subsubsection{Use of statistical data}

Import/export databases provide data on the flows of thousands of products and commodities between countries in physical and monetary units.

Used clothing and textiles and textiles waste (rags) are included along with other products in these databases.

However, neither the official import/export statistics nor the background statistical system allows for information on the types of used textiles exported, nor the intention for use. This is in stark contrast to new textile products that are represented by over 400 product and fibre types in the $\mathrm{CN}$-product code system and import/export data.

Used clothing and textiles are listed under two 8-digit $\mathrm{CN}$-product codes in import/export statistics, the second of which is further split into two sub-codes: 
- 6309 worn textiles and clothing.

- 6310 sorted and unsorted used or new rags and textile scraps.

- 63101000 sorted used or new rags and textile scraps.

- 63109000 unsorted used or new rags and textile scraps.

In theory 63101000 is split down into further subdivisions of different fibre types but in reality these are left blank in all statistics databases investigated (see also Watson et al., NCM internal report).

As already noted under section 2.1 , code 6309 should ideally be given to textiles fit for reuse, while 6310 should be given to textiles intended for recycling. However, unsorted textiles which include textiles both fit and unfit for reuse are typically categorised under 6309, rather than a mixture of 6309 and 6310 .

Export data indicates the country to which Nordic used textiles or rags are sent and total volumes (in $\mathrm{kg}$ ) and value of the exports (in local currency) under each of the codes.

Import/export statistical data is available from individual countries databases and also from EU and UN aggregated databases.

For this project we chose to use the UN Comtrade database. This would allow us to use a single source rather than accessing the various Nordic country national statistics offices. Moreover, the UN database has the additional value of identifying to which countries Nordic exports of used textiles have a particularly high share.

Using the Comtrade stats we carried out the following analysis for used textiles and rags:

- Internal trade between the four Nordic countries, 2011-2014

- Volume of exports from the four Nordic countries individually, and as a whole to other countries and regions, 2011-2014

- Identification of top 10 import countries for Nordic used textiles, 2014

- Calculation of the share of Nordic imports in the total imports of used textiles to these countries, 2014

It is important to note that calculation of total exports from the collected four Nordic countries includes exports to Iceland, Greenland, and the Faroe Islands, since these are identified as separate entities in the statistics databases. However, these volumes are small. 


\subsubsection{Survey of collectors}

The statistical database can only take us so far in mapping exports of used textiles. The data only provides the first country to which textiles are exported. Since not much sorting of textiles occurs in the Nordic countries, a significant proportion is exported to sorting facilities in European countries. Following sorting a significant proportion is likely to be re-exported again. It is not possible to follow this flow in Comtrade since no "Nordic label" is assigned to the re-exported textiles from intermediate countries.

A further weakness of the Comtrade data is that it can underestimate exports of used textiles. Exports intended for direct aid relief rather than sale donations rather than for sale in other countries, are typically not included in the statistics which have their basis in value transactions. Moreover, there can be cases where exports within Europe are not registered.

To gain a detailed and more robust picture of exports of used textiles we supplemented statistical data with information gathered from individual collection and exporting organisations. In the Nordic countries a handful of organisations are responsible for the major part of the collection. These are identified in Palm et al. (2014).

We carried out structured interviews of the top $2-4$ collectors in each of the four countries (see Table 1 in Section 1.2.3).

Key elements of the interviews included:

- Total volumes they collect.

- Quantities exported sorted (fully or partially) and unsorted.

- First receiving countries and partners/buyers.

- What guides choice of partners/buyers.

- The extent of their knowledge of, and influence over, the final destination and fate of used textiles.

- Whether the fate of Nordic textiles is different from that of other used European textiles sorted by the same buyers.

- What the end destination of various fractions is as far as they can trace.

- The degree to which destinations change year on year.

With respect to the last point used textiles are increasingly sold on the global market where prices can change relatively quickly. A snapshot of a single year may not be a reliable representative of average flows but given that most sorters have long term agreements with their customers/distributors the data should be fairly representative. 
Where possible, interviews were carried out via physical meetings rather than over the telephone to ensure better flows of information. Interviews were followed up by mails and phone calls where necessary to obtain supplementary information.

Follow-up information was also gained from European sorting partners such as SOEX group and BOER group.

Interviews were supplemented with data from mapping exercises carried out by Mepex of UFF/Humana organisations in Nordic countries since 2012 and in the rest of Europe since 2013. UFF/Humana is a key collector in all four of the Nordic countries included in this project.

With respect to point 6 , where textiles are exported to a central sorting facility somewhere in Europe it typically isn't possible to separately trace the fate of the Nordic textiles that are mixed together with textiles from many other countries. In these cases we assume that the Nordic textiles are treated in the same way as textiles from other sources i.e. their eventual fate is the same. For a few sorting facilities, the Nordic textiles dominate textiles arriving at the facility and certainty in the fate of Nordic textiles is higher

One flow that won't be picked up by either statistics or by contact with collecting organisations is the illegal/grey collection. This flow is by definition very hard to track down and previous efforts have failed (Palm et al. 2014). We have, therefore, not attempted to track this flow though it undoubtedly exists.

As can be seen from the questions in the questionnaire survey, the answers given are both quantitative and qualitative. The results presented later reflect this mixture. We want to know not only where textiles end, but also what guides this fate and whether there are conditions, which inhibit collectors from guiding this fate.

\subsubsection{Identifying Import Restrictions}

The global market for export of used textile is influenced by national trade regulations and international trade agreements. Many countries have in place a variety of obstacles to the import of used textiles based on one or several regulations.

The knowledge about these regulations can be an important element in understanding market conditions for the export of used textiles from Nordic countries and the social and economic effects in the destination countries.

The objective of this part of the report is to provide an overview of existing regulations and, where possible, to explain the background for the introduction of these regulations and also when a deregulation has taken place. The playing field is dynamic, developing within changing economic and political frameworks. 
The study is based on a combination of relevant literature and interviews with contacts working in the market for used textiles. It has not been possible to study the legislation and rules in different countries in detail, nor how they work in practice. The report is often based on sources that give relevant information, but do not necessary give a total picture or miss the most up-to-date information. Where possible, different sources have been cross-checked to ensure a certain level of control.

One of the key sources of information on national restrictions is the Office of textile and Apparel (Otexa) under the US International Trade Administration. ${ }^{3}$ The Administration maintains a table summarising national restrictions and requirements on imported worn textiles from around the world. We have, however, not considered all countries, but only those most relevant to the Nordic exports of used textiles.

\subsection{Flows of exported textiles}

\subsubsection{Separately collected textiles in Nordic countries}

Flows of new and used textiles in Nordic countries have already been mapped under separate projects both those funded by NCM (Palm et al., 2014; Tojo et al. 2012) and by others (Watson et al. 2014; Carlsson et al., 2011). The flows of clothing and household textiles (not including carpets) and similar textiles in business and public organisations (hospitals etc.) for Denmark, Sweden, Norway and Finland are shown in the figures below. These have been adapted from Palm et al., (2014). 
Figur 1: Textile flows in the four countries in tonnes (with data years)

\section{Denmark (2010)}

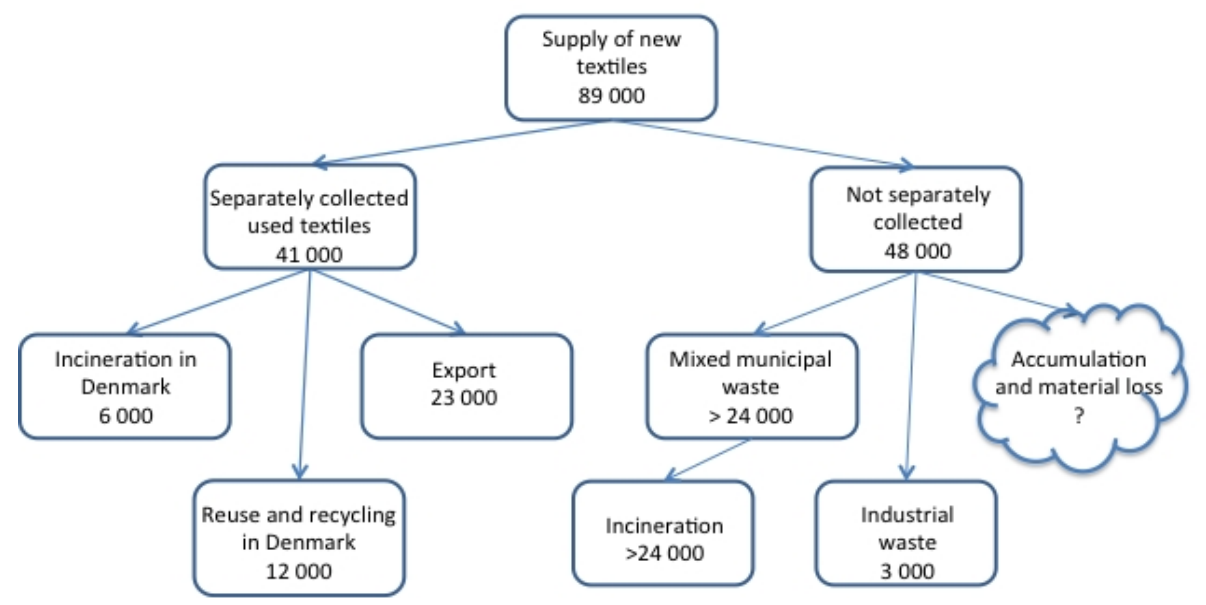

Norway (2011)

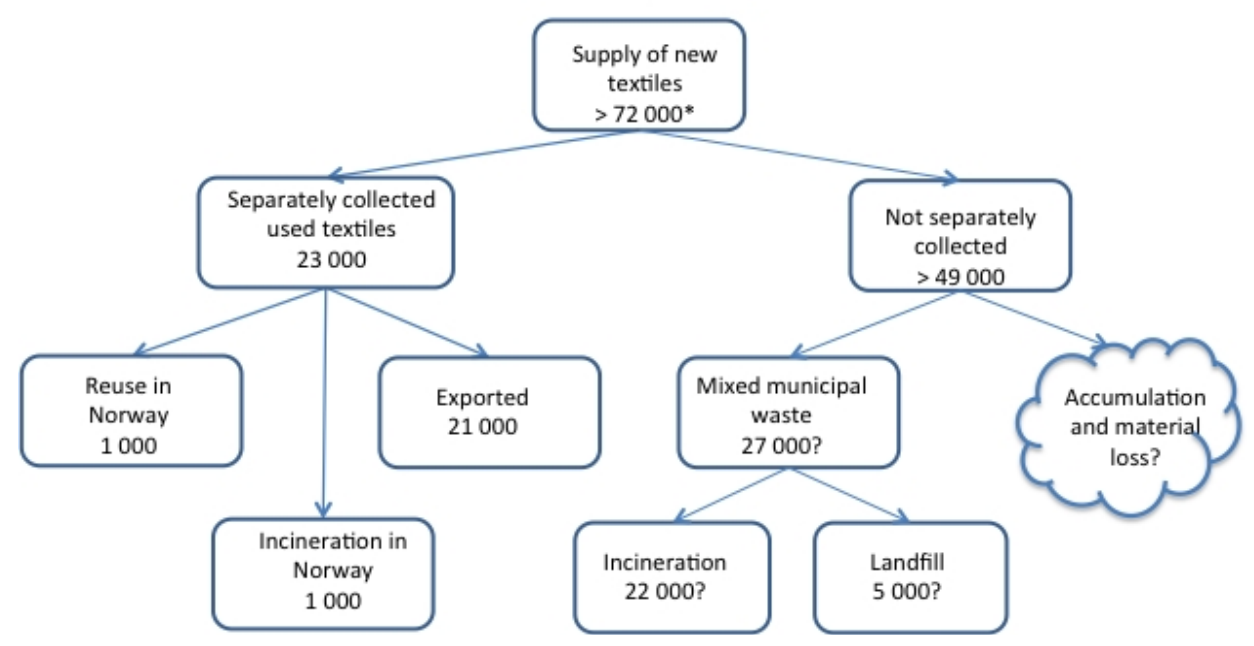




\section{Finland (2010)}
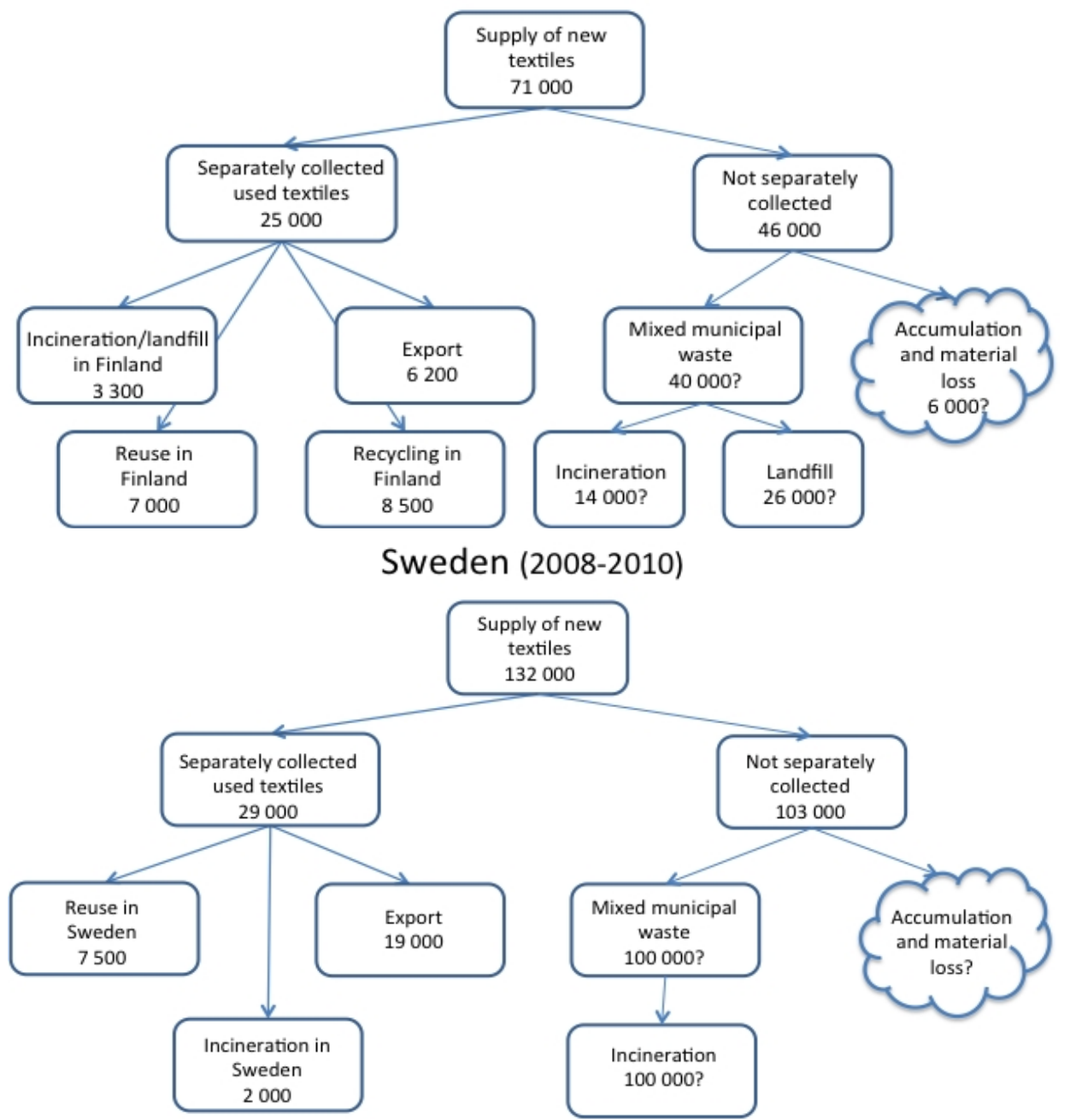

Note: Top chart: Finland 2010. Middle chart: Norway 2011. Bottom chart: Sweden 2008-2010.

For Norway the supply of new textiles put on the market is based on clothing only.

In 2013, textiles put on the Swedish market had reduced to 121,000 tonnes, and reuse increased to 8,600 tonnes, with export remaining at 19,000 tonnes (Elander et al., 2014). No figures are available for total separately collected volumes in 2013.

Kilde: Adapted from Palm et al. (2014). 
Whereas the separately collected quantities are reasonably well quantified, the flows of non-separately collected textiles can only be roughly estimated due to lack of widespread and regular sampling of the composition of mixed waste and bulky waste flows, and lack of knowledge on the quantities of textiles accumulated in households.

Between 22\% (Sweden) and 45\% (Denmark) of textiles put on the market end up being separately collected, mostly by charities (Palm et al., 2014a).

More than half of textiles collected in Finland remain in the country, while the majority of collected textiles in Denmark, Norway and Sweden are exported.

\subsubsection{Results from analysis of UN Comtrade data}

We begin by noting that all data and graphs shown in this section of the report show only the first destination for textiles exported from the Nordic countries, and according to Comtrade data not direct information from collectors. For final destinations one must look at Section 3.3.

The UN Comtrade data shows that exports of worn textiles increased from 60,000 tonnes in 2011 to just under 75,000 tonnes by 2014 almost entirely due to a sharp increase in 2014 (Figure 2). The quantities of exports of rags are much lower at 1,084 tonnes in 2014 (Figure 3). However, as noted earlier, and confirmed by interviews, most exports of used textiles from Nordic countries are unsorted and will include a proportion of rags which nevertheless have been recorded under $\mathrm{CN}$ code 6309 .

Figure 2: Export of worn textiles and clothing (code 6309), 2011-14

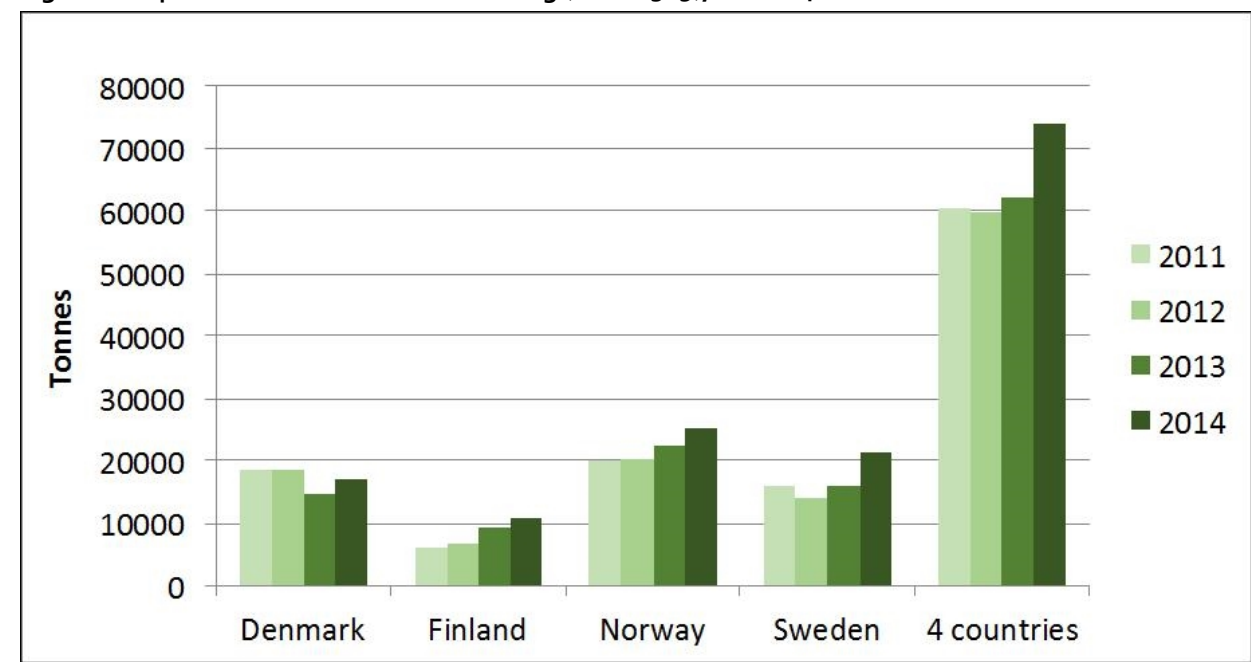


Figure 3: Export of rags (code 6310), 2011-14

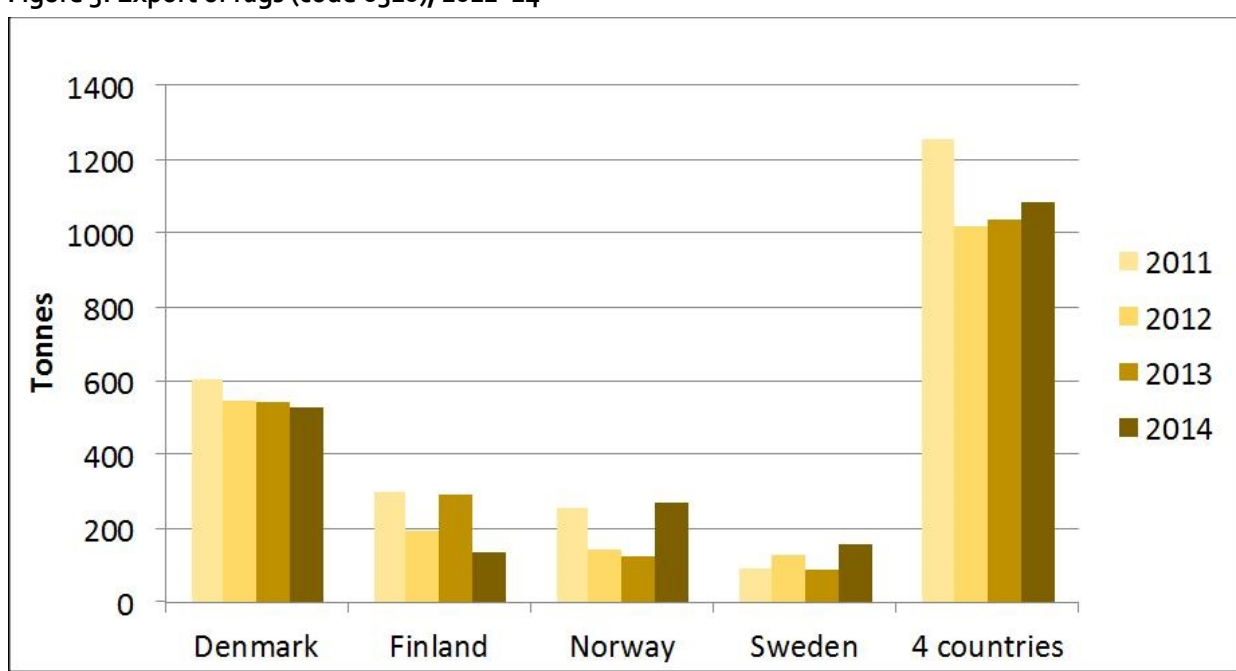

The fall in exports of rags may reflect a reduction in sorting taking place in Nordic countries.

Internal trade of worn textiles between the countries are shown in Figure 4. Interestingly, the internal trade of rags is similar in magnitude to the internal trade of worn textile. Flows of rags between the Nordic countries in fact exceed total exports of rags to the rest of the world. It thus seems as if a good portion of these rags are utilised within the receiving Nordic country for industrial use or otherwise. 
Figure 4: Internal Nordic flows of worn textiles and rags, 2014 (only flows exceeding 1 tonne are shown)

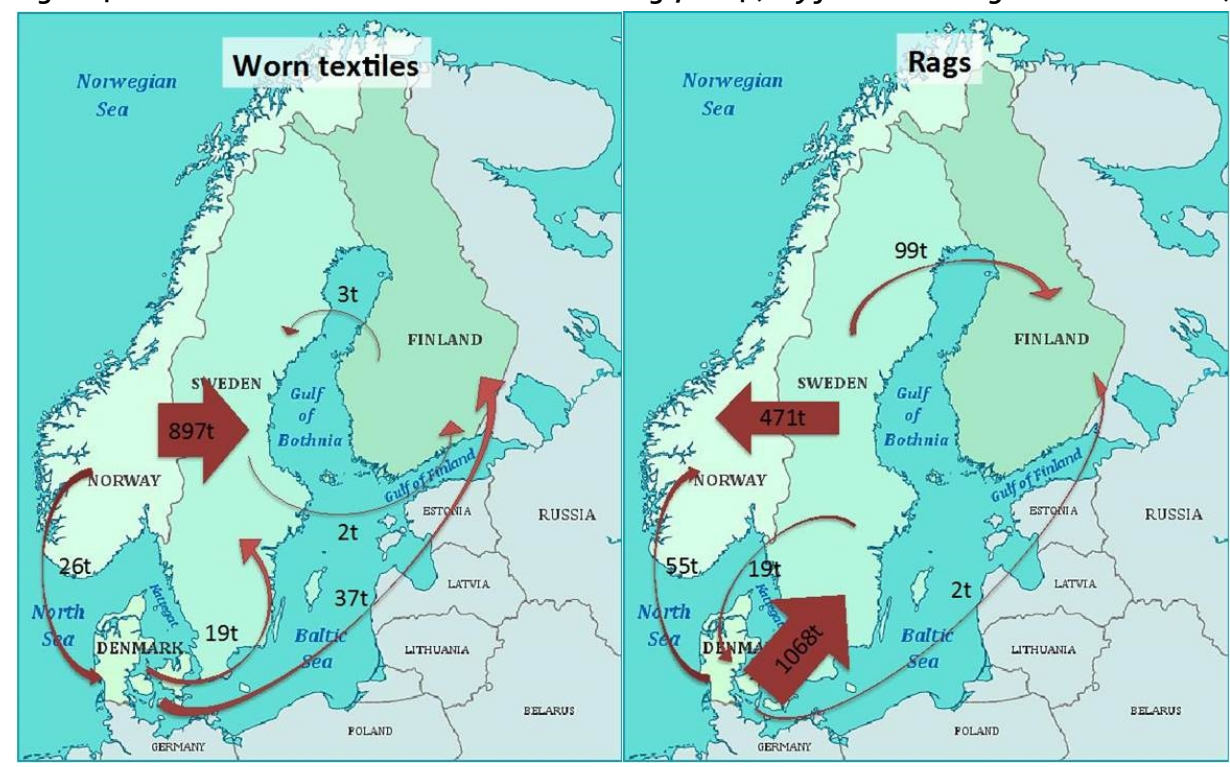

Internal trade of worn textiles is relatively insignificant compared with export to the rest of the world.

The UN Comtrade data also allows the identification of the Nordic countries most important trade partners. These are given below for both worn textiles ( $\mathrm{CN}$ code 6309) and rags (CN code 6310).

\section{Worn textiles}

Perhaps the most surprising result is that, according to the Comtrade statistics database, actors in Nordic countries directly exported to no less than 115 different countries in 2014. This gives an idea of the complexity of the modern market for used textiles. Figure 5 shows all countries which received over 100 tonnes of Nordic used textiles in 2011 and 2014. A corresponding table is presented in Appendix A.

The flows are dominated by direct exports to just a handful of countries, almost all European. Seven out of the eight countries that received over 3,000 tonnes of Nordic used textiles in 2014, are European. Among these Poland, the Baltic countries, Belgium, Bulgaria and Germany are known to have a number of large sorting facilities and may represent interim destinations for the textiles. 
Figure 5: Countries that received more than 100 tonnes of worn textiles from the Nordic region, 2011 and 2014
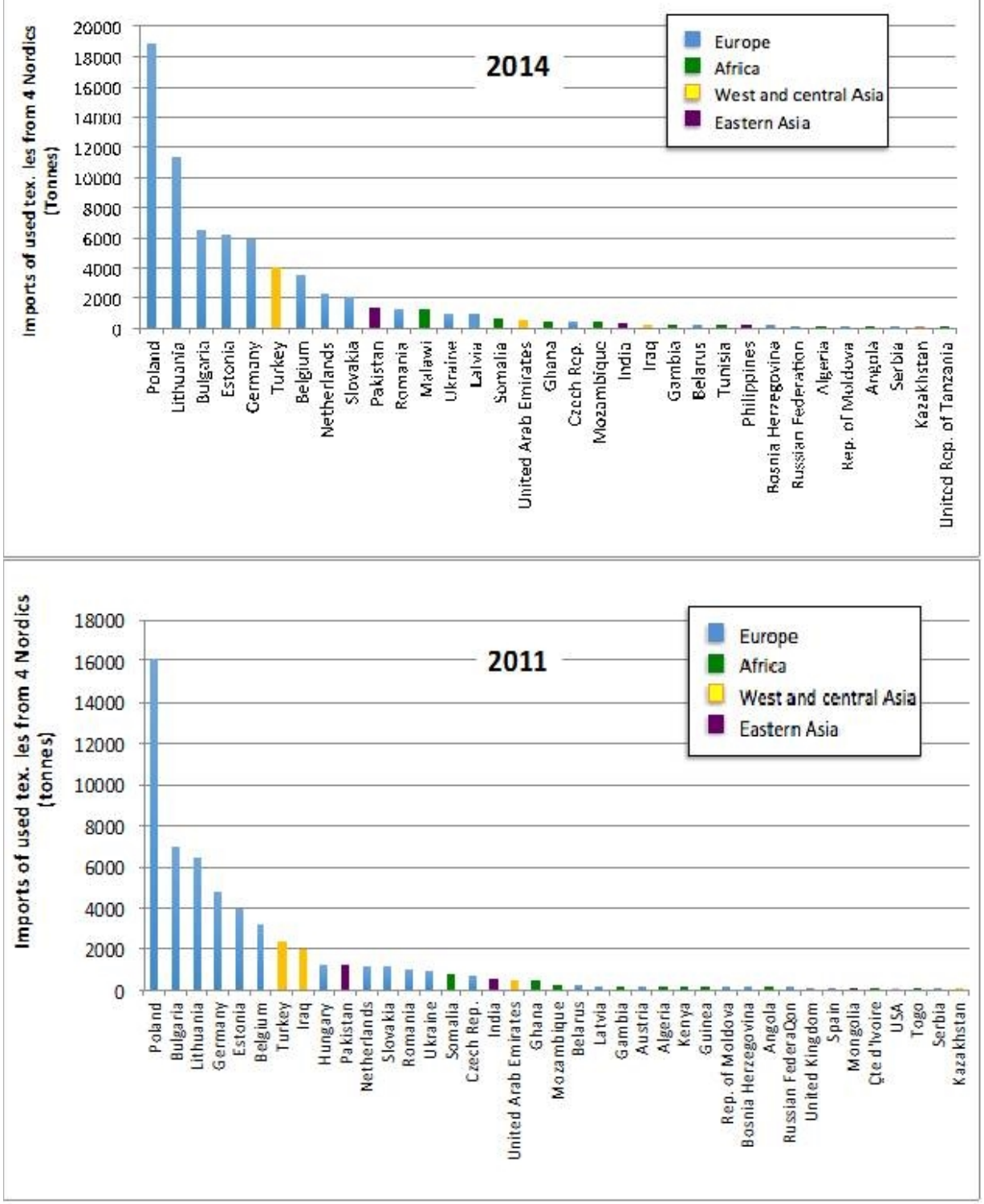
Nine African countries, three East Asian and three west Asian countries also receive over 100 tonnes of worn textiles from the Nordic countries. These are more likely to be final destinations. Of these Turkey, Pakistan and Malawi received over 1,000 tonnes of textiles, while Somalia, United Arab Emirates and Ghana received over 500 tonnes.

All four Nordic countries are exporting to key European sorters like Poland, Lithuania and Germany. There are greater differences as one moves further afield. It is Sweden and, to a lesser extent Norway, exporting to Turkey and Pakistan, Finland exporting to Malawi and Sweden to Somalia and Ghana (see Appendix A for country level data).

Destination countries for worn textiles changed little between 2011 and 2014 (Figure 5). The top seven importers remain unchanged. The most noticeable developments were a reduction in the importance of Iraq, and the appearance of Malawi as the most important African destination.

Figure 6: Imports from Nordic countries as share in total imports of worn textiles

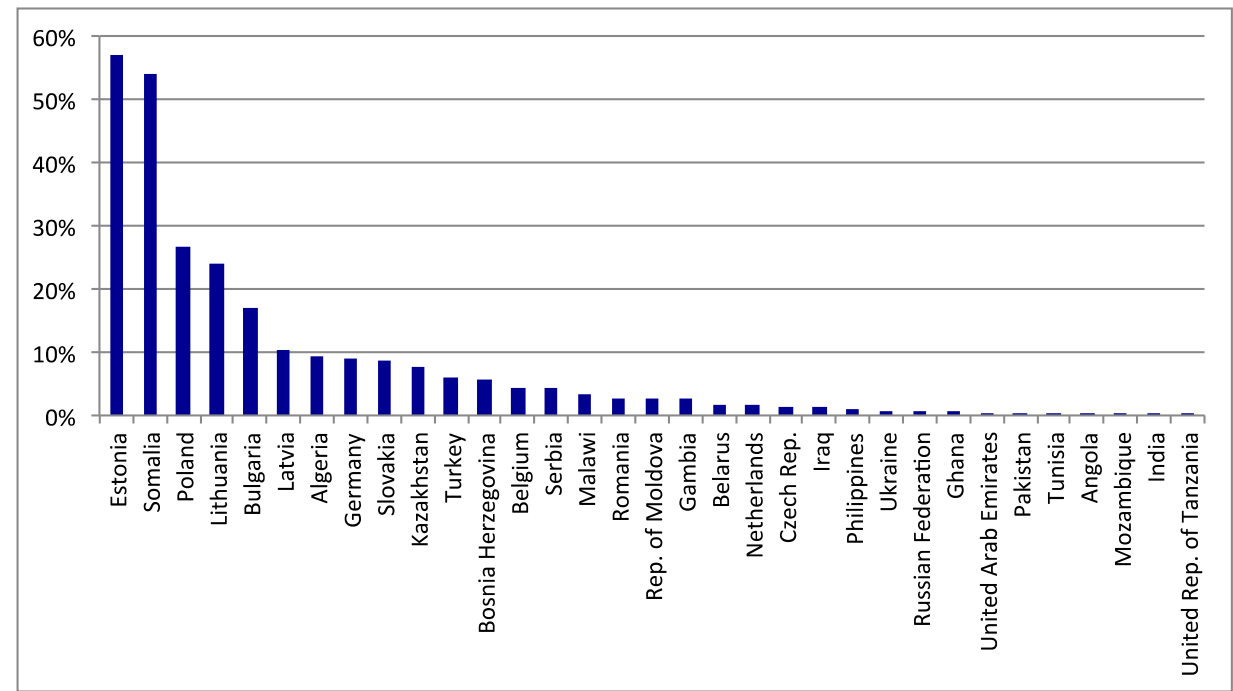

Nordic used textiles make up more than $10 \%$ of imported used textiles in six countries, which are with one exception (Somalia) from eastern Europe and the Baltics (Figure 6). Over $50 \%$ of used textiles imported to Somalia and Estonia have Nordic origin. Here Nordic countries have a particular responsibility to ensure that textiles have a positive overall social and economic effect.

At the other end of the scale, Nordic textiles have an inconsequential share in used textiles imported to countries like Ghana, India and Pakistan. The importance of some of these countries at the lower end may increase somewhat as we find out more about the final destination of textiles sent to European countries for sorting. 


\section{Rags}

Export destinations for rags show a very different pattern with a much higher ratio of Asian countries. This is because the rags have already been sorted and we can assume that these are the rags final destinations. India and to an increasing extent, Thailand have significant industries for shredding and unravelling textiles for use in production of low grade textile products like rugs.

As already noted, however, the overall quantities of direct exports of rags out of the Nordic countries are insignificant in comparison to flows of worn clothing and other textile products. However, this picture may chance when indirect flows following sorting are considered under Section 3.3 below.

Figure 7: Countries that received more than 5 tonnes of rags from the Nordic region, 2014

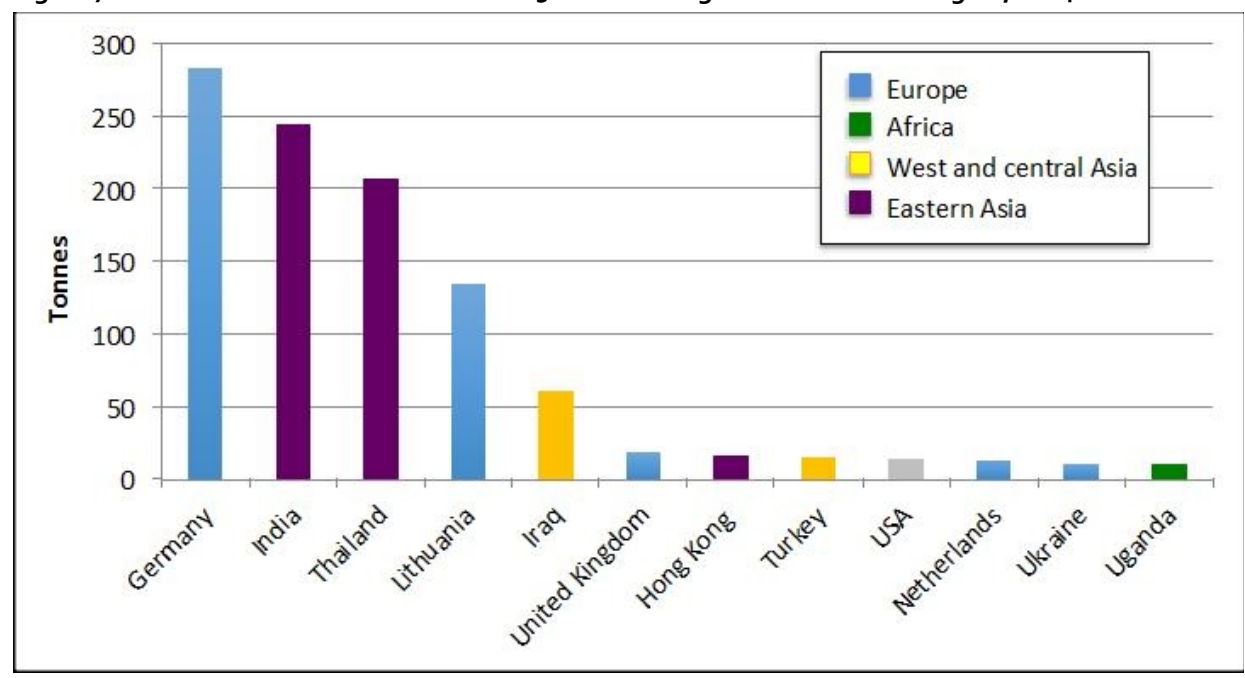

\subsubsection{Results from collectors surveys}

\section{Collection and export quantities}

We interviewed 13 collectors from the four Nordic countries. In 2014, these organisations collected a total of 82,800 tonnes of donations in their textiles containers and shops. This represents around $70 \%$ of total estimated used textiles collection in the countries (see Figure 1 earlier).

The collected quantities for the most part include shoes and waste, although some collectors (notably UFF/Humana) remove large non-textile waste items before weighing. Shoes make up typically $5 \%$ of the total weight after waste has been removed. 
The collectors have different strategies for both collecting and post collection. Some collect only via containers (i.e. UFF and Trasborg) but where the collectors also have shops, collections are also made in these. For example, the Danish and Swedish Red Cross collect $60 \%$ and $100 \%$ respectively of their textiles in shops. Shop collection gives a higher quality textile and a much smaller percentage of waste. Some organisations carry out some level of sorting of textiles following collection. Those organisations with shops in the collecting country (all organisations except Trasborg and UFF Denmark, UFF Norway and Humana Sweden, ${ }^{4}$ typically sort a sufficient share of collected textiles to yield enough high quality textiles for sale in their shops. This sorting may occur in the shop or in a central warehouse. Between 10 and $20 \%$ is normally suitable for sale in shops.

Non-textile waste and sometimes also textile waste is also removed during this partial sorting. A few organisations also carry out more thorough sorting. For example, Trasborg fully sorts textiles into 110 different categories for export. The Finnish Red Cross carries out detailed sorting but mostly for domestic purposes, only exporting a little under a quarter. More typically, however, following removal of textiles for own sale and non-textile waste, textiles are sold on the export market as partially sorted - otherwise called pre-sorted in the trade.

Table 1: Collection and export of used textiles* by 13 interviewed Nordic collectors

\begin{tabular}{llrrrr} 
Organisation & Country & Collected in 2014 (tonnes) & \multicolumn{2}{c}{$\begin{array}{c}\text { Exported in 2014 (tonnes) } \\
\text { Unsorted ("original") }\end{array}$} & Pre-sorted \\
& & & & 736 \\
Emmaus Björkå & SE & 3,200 & 1,440 & 700 \\
Human Bridge /Returtex & SE & 6,800 & 6,000 & 1,000 \\
Swedish Red Cross & SE & 5,000 & & \\
Humana, Sweden & SE & 3,049 & 3,049 & \\
Myorna** & SE & 7,900 & & \\
Fretex** & NO & 15,150 & $15,200^{* * *}$ & $5,800^{* * *}$ \\
UFF, Norway & NO & 8,837 & 8,837 & \\
Finnish Red Cross & FI & 1,000 & & 230 \\
UFF, Finland & FI & 12,064 & 7,291 & 4,090 \\
UFF, Denmark & DK & 1,467 & 1,467 & \\
Salvation Army & DK & 5,750 & 3,738 & 978 \\
Danish Red Cross & DK & 6,890 & 128 & 4,800 \\
Trasborg & DK & 5,700 & 4,208 & 760 \\
Total & & 82,807 & 51,358 & 19,094 \\
\hline
\end{tabular}

Note: * Including shoes and in the case of unsorted textiles also non-textile waste.

**Myrorna and Fretex cooperate in exporting collected textiles via the organisation Fretex International.

$* * *$ These represent the combined exports of Myrorna and Fretex via Fterex International

${ }^{4}$ Actually UFF has two shops in Norway and four in Sweden but no textiles are skimmed off from collections to supply these. 
All interviewed organisations apart from the Finnish and Swedish Red Cross organisations also export "original" i.e. completely unsorted textiles in the same composition as they were collected. This contains both textile and non-textile waste (though UFF/Humana remove large pieces of non-textile waste prior to export). The share between sorted and unsorted exports is often related to the organisation's own capacity for sorting. When this has been reached, everything else is exported as unsorted ("original"). Three quarters of exported used textiles are unsorted.

The split between sorted and unsorted textiles is shown in Table 1.

Most collectors report an increase in competition in collection over the past few years as more actors, both legal and illegal, enter the market. The established actors have attempted to maintain collection quantities by increasing the number of containers they operate. Individual campaigns can also increase donation and collection rates. The Danish Red Cross' Smid Tøjet campaign in June 2015, has led to a recent increase in collection via all Danish collectors not just the Red Cross.

In Sweden several collectors are experiencing increasing volumes which could be due to new focus from municipalities.

Overall, 8 out of 13 collectors report increasing collection over the past couple of years (Figure 8).

Figure 8: Share of collectors with increased collection over past few years?

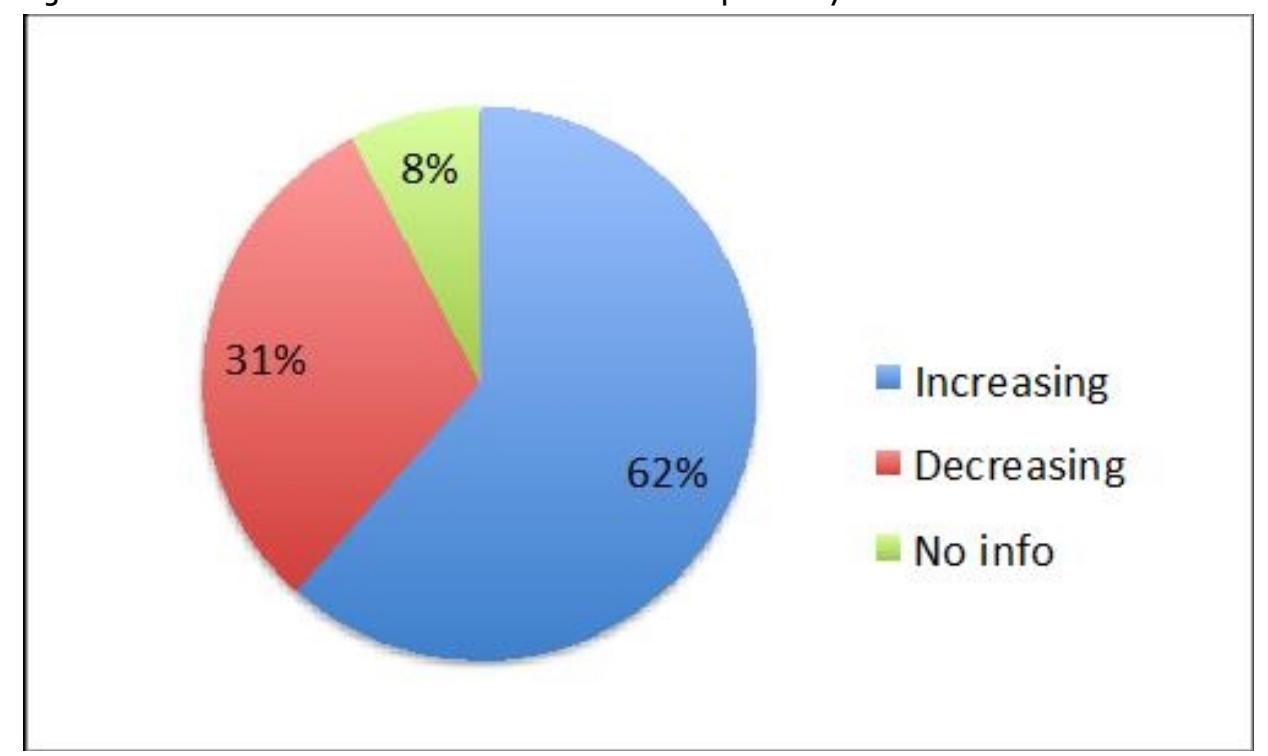


First destinations of exported textiles

All collectors were willing to share information with us on the first destination of direct exports, though in some cases information on exact quantities was rather vague.

The collectors reported a total of 30 different countries to which they directly exported textiles in 2014. This is significantly less than the 115 identified in the UN Comtrade data. It should be remembered, though, that while the 13 organisations represent around $70 \%$ of total collection; there are many other organisations operating that may be sending small amounts to a large number of other countries.

The primary purpose of exports of used textiles is to raise money for the organisation's charitable operations (or for profit for the single interviewed collector not registered as a charity). Textiles are mostly sold to wholesalers or second-hand retail chains (Figure 9).

Figure 9: Share of collectors engaging in various export activities

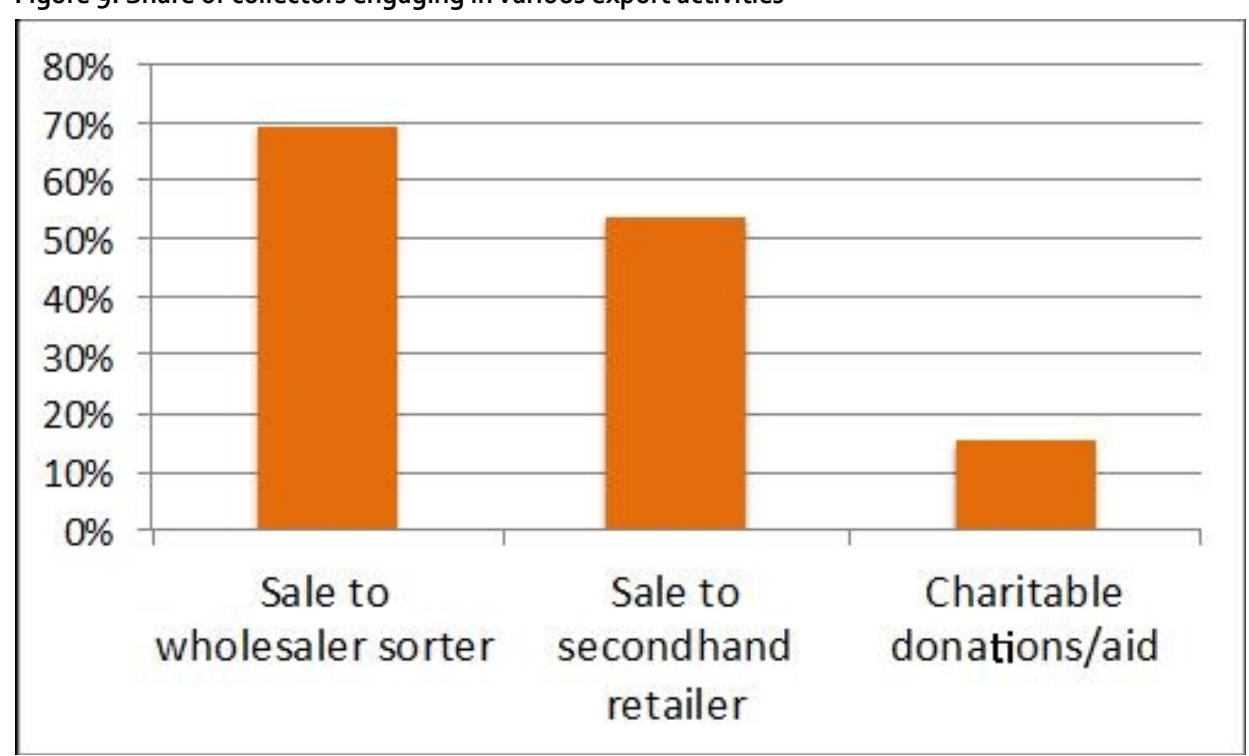

Using textiles directly in humanitarian work or as crisis aid is much less usual than it was two decades ago. Of the collectors interviewed only the Finnish Red Cross still uses textiles directly in aid via the Red Cross Network. One further example of a donation-based export is Human Bridge/Returtex which exports to other church-based charities in Baltic countries and the Ukraine to support the social welfare projects of those charities. UFF has also been known under special circumstances to buy back textiles following sorting by their partners in Humana, to donate to particular aid projects in Africa and elsewhere. 
Figure 10 and Table 2 show the first destinations for sorted and unsorted textiles exported by the 13 collectors. The first destination of 1,787 tonnes could not be determined and are, therefore, not included in the map but are included in Table 2. 
Figure 10: First destinations of Nordic used textiles exported by the 13 interviewed collectors (see also Table 2)

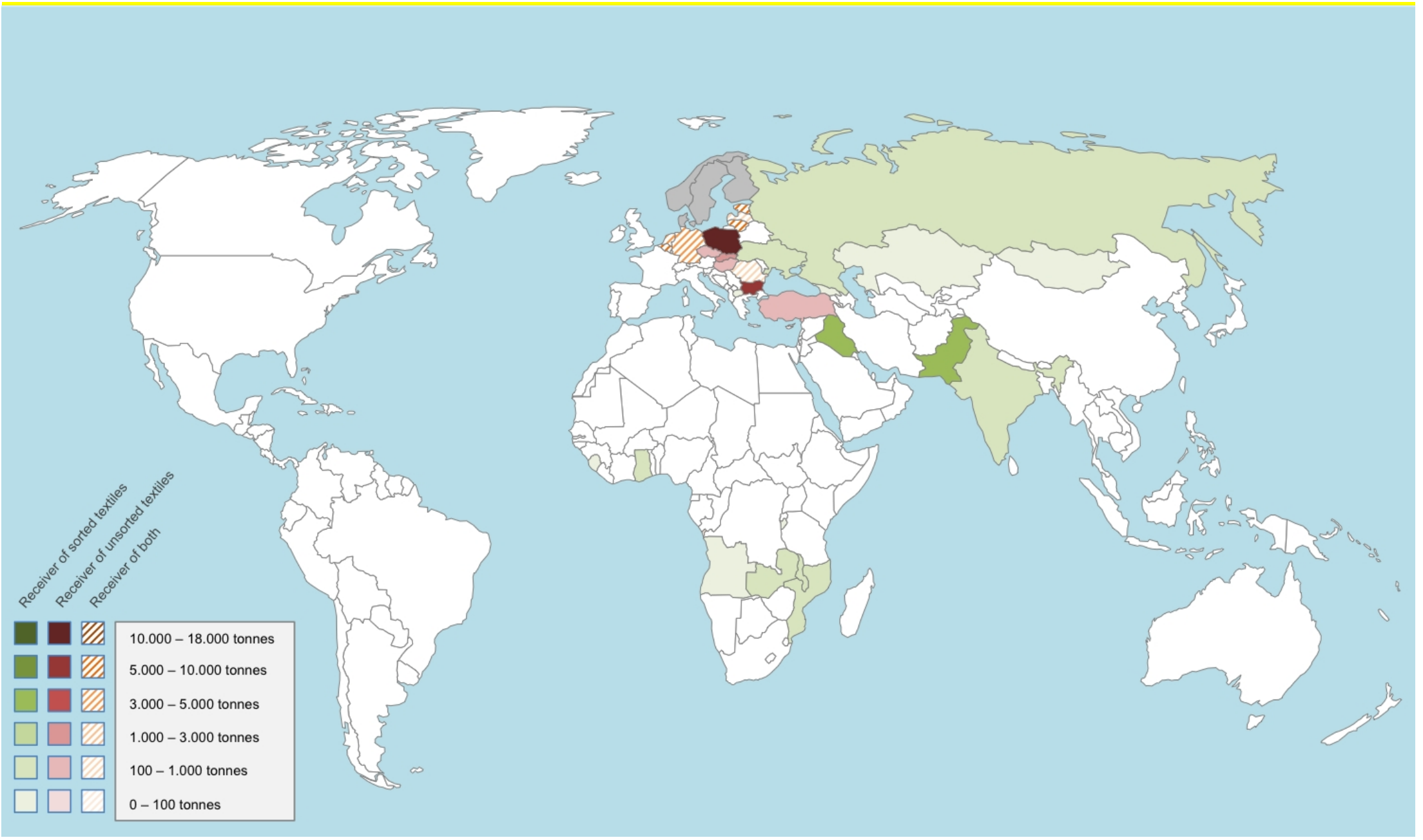


Table 2: First destination of Nordic used textiles exported by the 13 interviewed collectors

\begin{tabular}{|c|c|c|c|}
\hline Country & Pre-sorted (tonnes) & Unsorted (tonnes) & Total (tonnes) \\
\hline Poland & & 17,591 & 17,591 \\
\hline Bulgaria & & 8,146 & 8,146 \\
\hline Lithuania & 459 & 7,555 & 8,014 \\
\hline Estonia & 175 & 7,337 & 7,512 \\
\hline Belgium & 3,987 & 2,164 & 6,151 \\
\hline Germany & 1,933 & 2,260 & 4,193 \\
\hline Iraq & 3,828 & & 3,828 \\
\hline Netherlands & 1,543 & 2,187 & 3,730 \\
\hline Slovakia & & 1,812 & 1,812 \\
\hline Pakistan & 1,681 & & 1,681 \\
\hline Romania & 150 & 765 & 915 \\
\hline Malawi & 609 & & 609 \\
\hline Mozambique & 609 & & 609 \\
\hline Zambia & 609 & & 609 \\
\hline Czech Rep. & & 532 & 532 \\
\hline Turkey & & 524 & 524 \\
\hline India & 484 & & 484 \\
\hline Hungary & 25 & 380 & 405 \\
\hline Ghana & 388 & & 388 \\
\hline Latvia & 175 & 56 & 231 \\
\hline Ukraine & 210 & & 210 \\
\hline Russia & 161 & & 161 \\
\hline Kazakhstan & 98 & & 98 \\
\hline Mongolia & 65 & & 65 \\
\hline Angola & 64 & & 64 \\
\hline Sierra Leone & 45 & & 45 \\
\hline Macedonia & 36 & & 36 \\
\hline Burundi & 15 & & 15 \\
\hline Georgia & 7 & & 7 \\
\hline Unspecified & 1,787 & & 1,787 \\
\hline Total & 19,145 & 51,307 & 70,452 \\
\hline
\end{tabular}

With one exception (Turkey) unsorted exports are reported as going to wholesalers/ partners in European countries for sorting. This is primarily Poland, Estonia, Lithuania and Bulgaria but with significant quantities going to Germany, Belgium and the Netherlands where some of the larger textile sorting groups (e.g. Boer group) have facilities.

This is a key finding, since exports of waste, both textile and non-textile, are primarily associated with exports of original (unsorted textiles). If this is only exported within the EU one could assume that the waste included in exports is treated responsibly. Of course, this may mean landfilling which lies lower down the waste hierarchy than the incineration, which it would (mostly) have been sent to if it had remained in the Nordic countries, but it should not mean fly-tipping. The possible exception is Tur- 
key, the only non-EU country to which original is exported to. This may need to be the subject of further assessment.

With respect to sorted textiles, these are exported by the 13 collectors to European partners, but in addition there are significant exports to the Middle East, Asia and Africa. Two of the largest reported direct receiving countries are Iraq (3,828 tonnes) and Pakistan (1,681 tonnes).

\section{Choosing Partners}

While the primary purpose of collecting used textiles is to raise money for charity work (or profit), organisations identify other key considerations when choosing partners (Figure 11).

Figure 11: Share of collectors identifying different factors as important in the choice of partner/buyer

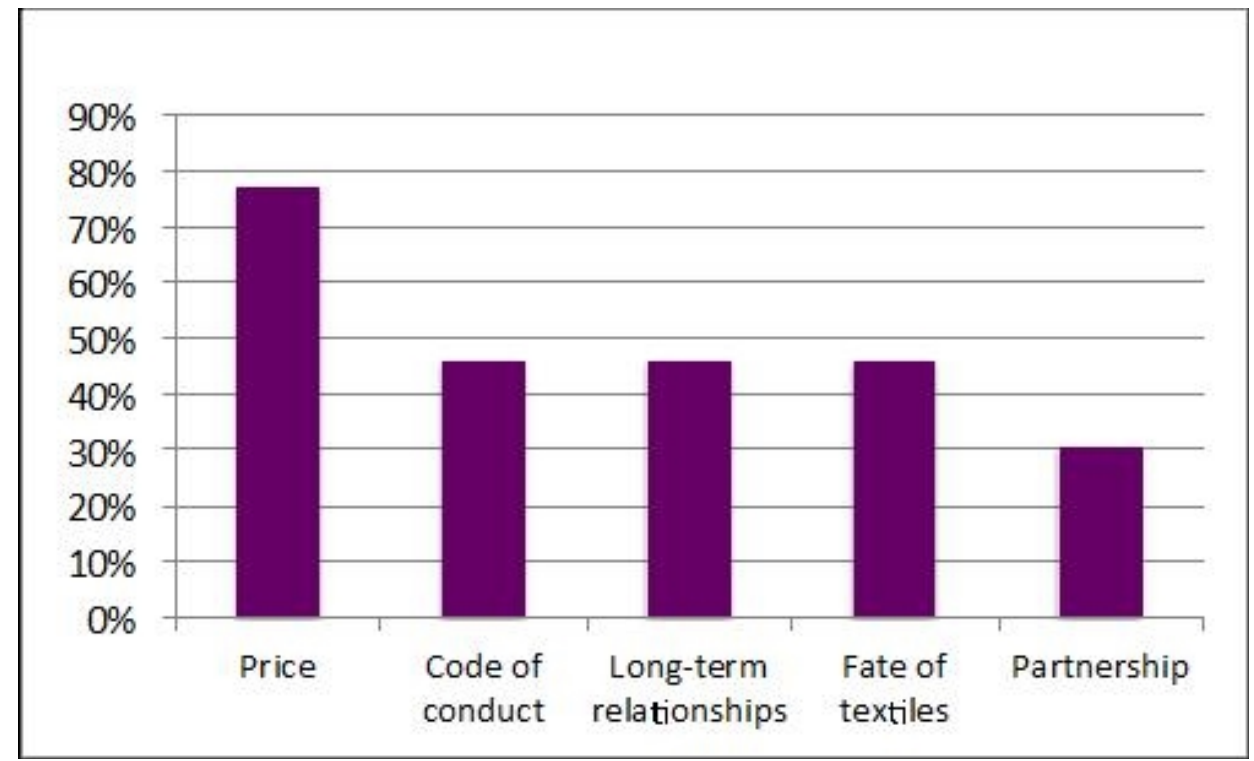

Trust is a key issue whether or not this is accompanied by a code of conduct. This can be simple trust in that the partner pays on time, and knows what to expect in terms of textile quality from the collector.

Collectors, therefore, tend to keep the same buyers over many years, with prices typically reviewed on a six monthly basis. Others, such as UFF have a stronger bond with their buyers via umbrella charity organisations.

Most organisations have a code of conduct or equivalent for their partner/buyers (Figure 12). Codes of conduct are often concerned with working conditions and minimum pay for workers. Myrorna, however, includes a requirement for reuse and recycling in the code of conduct they have with buyers, and carry out both internal and 
external review of their buyers. The Humana/UFF organisations also carry out external reviews of sorting partners in order to maximise reuse and recycling as far as possible.

Some other organisations are considering developing these kinds of conditions in the future.

Other types of conditions have been imposed by brands donating unsold clothing to charities. The Danish Red Cross reported one high street clothing chain that donates unsold collections to the charity, specifies that these must not be resold in countries where that clothing chain has outlets. Similarly, surplus textiles received by the Finnish Red Cross from retailers have to be exported as aid rather than being sold in their Finnish shops.

Knowledge of, and influence over, subsequent fate

Collectors who have a code of conduct for their buyers or have a strong partnership under an umbrella organisation can obtain information on what subsequently happens to the textiles. However, the share of collectors that actually received this information in report form, or otherwise was more limited (Figure 12).

Figure 12: Share of collectors identifying codes of conduct and reporting requirements for buyers/partners

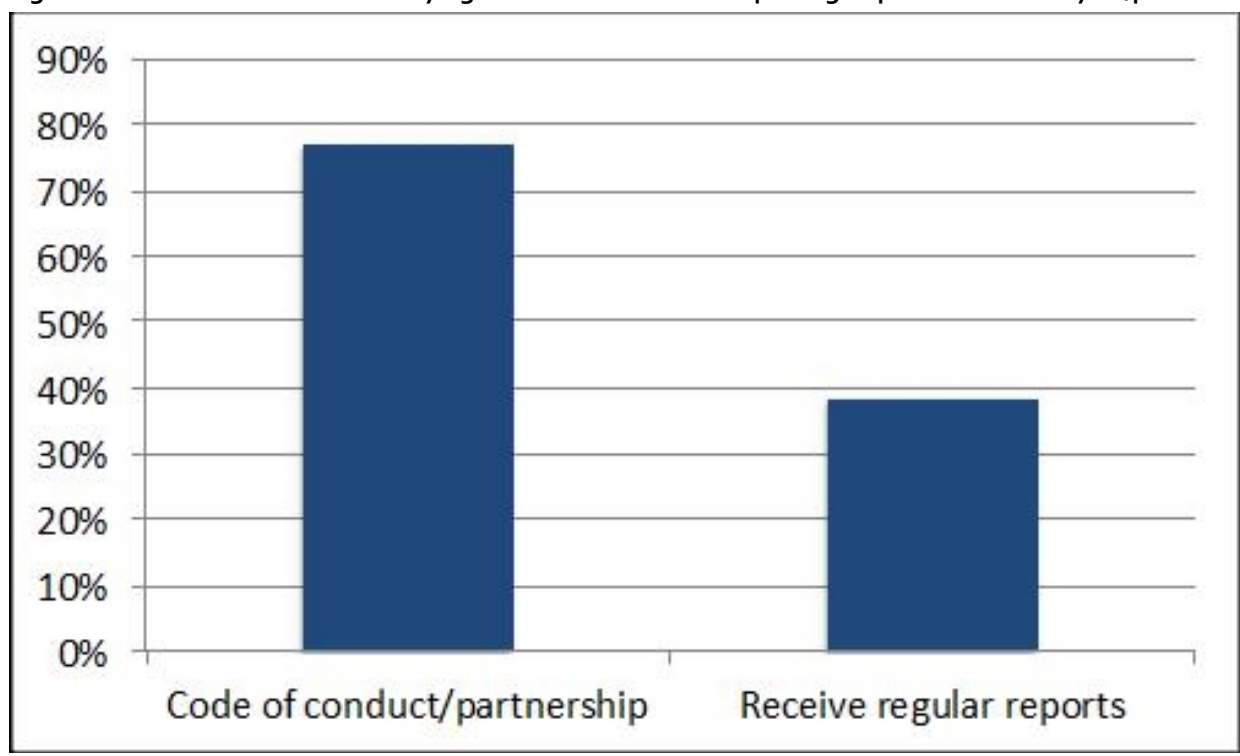

This led to problems in obtaining data from collectors on subsequent fate. In most cases, collectors, were willing to assist us but had to make special requests from their buyers for information. Due to lack of detail in the first response from the buyers and 
the lack of time of the collectors to follow this up, some of the data we received was rather basic (see later).

The most detailed and useful data was obtained from organisations who already receive regular reports from buyers, following defined formats. We can hope that this will be required by more collectors in the future.

Most collectors currently have limited influence over the eventual fate of the textiles they sell. Where they do, this is indirectly through partnerships with the umbrella organisations who are responsible for the fate of the textiles (Figure 13).

Figure 13: Share of collectors who have influence over the fate of collected textiles

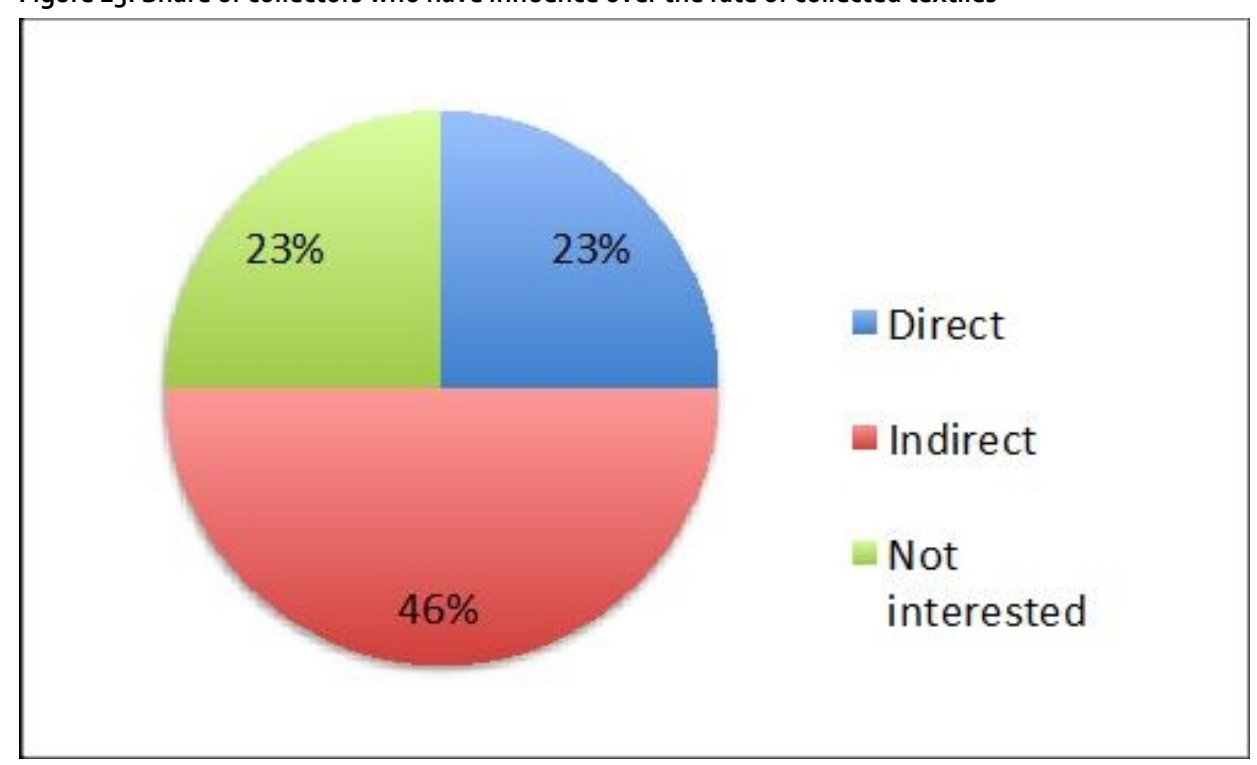

The exceptions in this regard is Swedish Myrorna who as earlier noted have requirements on buyers for reuse/recycling of textiles and UFF Norway's initiatives in India to improve working conditions in recycling operations.

Some buyers such as I:Collect have their own set of principles for reuse and recycling. UFF Norway is also engaging directly in recycling projects in India.

\section{End destinations for used textiles}

While almost all collectors provided us with some information on the eventual fate of the textiles they sell to sorters/wholesalers, the data is far from comprehensive. ${ }^{5}$

\footnotetext{
${ }^{5}$ One collector had the data in detail but was not willing to give it to us for confidentiality reasons.
} 
Typically, information from a single buyer of several has been provided. Moreover, information sometimes only lists countries which products are exported to without proving a breakdown by quantity or type.

It should also be mentioned that no buyers have information on what specifically happens to textiles they buy from Nordic collectors. Information given is for all textiles purchased by the wholesaler. For some buyers, however, in Bulgaria and Poland, the Nordic textiles constitute a clear majority of total textiles and here the fate of the Nordic textiles is more precise.

Some collectors claim that Nordic textiles have a higher than average quality and therefore have a different fate to the average European textile. This is backed up by a higher price given for Nordic textiles DKK 6/kg on the market compared to for example DKK ${ }_{4}-5 / \mathrm{kg}$ for Dutch/Belgian textiles. However, without more concrete information on this, we assume that Nordic textiles follow the same routes as the average European textile from a given sorter.

A summary of the assumptions we made to build a map of final destinations for Nordic textiles is as follows:

- Nordic textiles sorted by a sorter collecting textiles from a number of different countries followed the average distribution pattern for the plant.

- Where distribution data was given for the largest buyer but no others, we assumed that the remaining buyers from that collector, distributed the textiles according to the same pattern.

- Where a certain grade of textiles was sent from a sorter to a group of countries but without providing a share for each country, we assumed that those textiles were distributed evenly between the relevant countries.

- Unless we received other information we assumed that exported sorted textiles were utilised in the country they were first exported to.

- Unless we received other information we assumed that re-exported textiles from sorting facilities in other countries (for example, Poland) are utilised in the country to which they are re-exported i.e. they do not go through any further re-exports.

In cases where we received no information at all about the destination of a fraction we made no assumption as to its fate but left it as an unknown.

Final destinations of textiles according to these assumption are shown in Figure 14 and Table 3 . Some 6,650 tonnes (approx. $10 \%$ of total) could not be assigned to a specific country even using the assumptions above, but could be traced to a region. A further 
7,000 tonnes (a further $10 \%$ of the total) could not be traced at all following arrival at the first destination. These are not shown in the map but are given in Table 3 .

Eastern European countries remain important final destinations but nonEuropean countries also become important in a way that isn't visible in the statistical data in Section 3.2 of this report: Pakistan is the second biggest final destination at over 5,000 tonnes and India imports around half of that. Moreover, over 12,000 tonnes, or $18 \%$ over the total exports end in the African continent. 
Figure 14: Estimated final destinations of Nordic used textiles exported by the 13 interviewed collectors (see also Table 3)

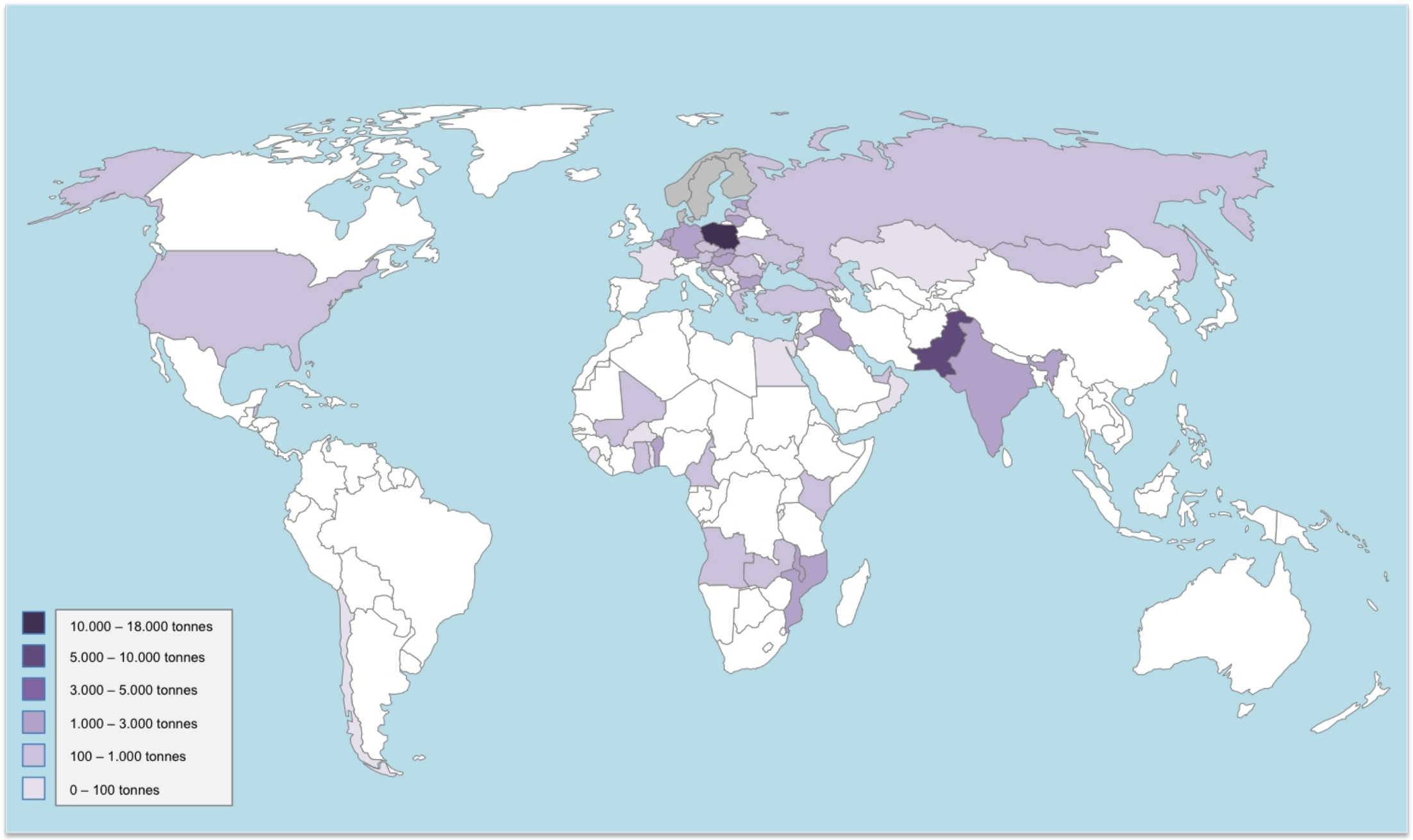


Table 3: Estimated final destinations of Nordic used textiles exported by the 13 interviewed collectors

\begin{tabular}{|c|c|c|c|}
\hline Country & $\begin{array}{r}\text { Imported textiles } \\
\text { (tonnes) }\end{array}$ & Country & Imported textiles (tonnes) \\
\hline Poland & 13,810 & Greece & 227 \\
\hline Pakistan & 5,103 & Kenya & 205 \\
\hline Iraq & 4,217 & Jordan & 205 \\
\hline Bulgaria & 2,899 & Austria & 162 \\
\hline Estonia & 2,821 & Slovenia & 162 \\
\hline Lithuania & 2,405 & Croatia & 150 \\
\hline India & 2,396 & Mongolia & 144 \\
\hline Netherlands & 1,553 & USA & 106 \\
\hline Belgium & 1,550 & Kazakhstan & 98 \\
\hline Germany & 1,478 & Serbia & 88 \\
\hline Russia & 1,462 & Burkina Faso & 79 \\
\hline Malawi & 1,407 & Togo & 79 \\
\hline Slovakia & 1,364 & Chile & 70 \\
\hline Hungary & 1,311 & France & 70 \\
\hline Mozambique & 1,193 & Oman & 70 \\
\hline Benin & 1,036 & Sierra Leone & 45 \\
\hline Romania & 965 & Macedonia & 36 \\
\hline Angola & 922 & Egypt & 25 \\
\hline Zambia & 893 & Burundi & 15 \\
\hline Latvia & 871 & & \\
\hline Czech Rep. & 713 & Unspecifiable by country & \\
\hline Cameroon & 666 & Africa & $5,53^{8}$ \\
\hline Belize & 600 & South America & 900 \\
\hline Ukraine & 591 & Middle East & 187 \\
\hline Turkey & 420 & Western Europe & 32 \\
\hline Ghana & 388 & & \\
\hline Georgia & 381 & Unspecifiable by region & \\
\hline Lebanon & 371 & Global & 7,073 \\
\hline Mali & 308 & & \\
\hline UAE & 241 & Grand Total & 70,452 \\
\hline
\end{tabular}

Quality, end destination and treatment of textiles

The end destination is often determined by the quality of the textiles. Only a few of the organisations have reported on this, and mostly via information provided by buyers. Typically, the highest quality textiles remain in the Nordic countries or elsewhere in Europe, primarily in the east including Russia.

So-called tropical mix and lower quality textiles are typically exported to Africa, the Middle East and Central Asia. As the name suggests, tropical mix is not necessarily of lower quality than fractions sold on the European market, but comprises clothing better suited to warm climates.

Textile waste (i.e. non-reusable textiles), meanwhile, either remains in Europe in the sorting country, where it is processed into industrial cloths or otherwise recycled (mostly downcycled) or disposed of, or exported to eastern Asia for mechanical recy- 
cling. According to the collectors this latter is primarily India and Pakistan. Very little textile waste ends in African countries.

Beyond this breakdown it wasn't possible to identify where individual used textile types are sent, broken down either by type of article (shirts, trousers, blouses etc.) or fibre type.

While partially implicit in destinations, the final treatment of exported textiles as a share has only been reported on by a few organisations.

There are obviously clear differences between final treatment of unsorted exports and of pre-sorted exports:

- Pre-sorted textiles have been largely filtered for non-recyclable textile waste, which is removed and treated in the Nordic collection country. This reduces risks for the importing country. Exported "original" (unsorted) textiles will include nonrecyclable textile waste and non-textile waste. These are removed and treated in the sorting country. Since all exported original is sorted within Europe this, at least in theory, should end in official treatment facilities: incineration or landfill.

- Pre-sorted textiles have typically been filtered for the highest quality textiles, which means a higher percentage is second-grade (ending in Africa, Middle East etc.) and rags for recycling (ending in Asia).

Myrorna/Fretex report that for their exported original, $81 \%$ is reused $-4 / 5$ of that in the sorting country - and $17.2 \%$ is recycled almost entirely in the first sorting country. The remaining $3 \%$ is incinerated or landfilled but we don't have a figure on this split.

$75 \%$ of their exported pre-sorted is reused as second grade, mostly in the Middle East, while $24 \%$ is recycled (in sorting country and east Asia).

The UFF organisations report similar breakdowns as UFF for their exports of original: $80 \%$ reuse (mostly in Europe and Africa), $16.5 \%$ recycling (east Asia and Europe), and $3.5 \%$ waste treatment in the original sorting country (Eastern Europe and Baltics).

Other organisations report a higher percentage of non-recycled waste in the original: $10 \%$ or more. Again this is treated in the sorting country. 


\subsection{Import restrictions}

\subsubsection{Overview of restrictions in selected countries}

There is a strong demand for reusable textiles across many parts of the globe, giving poor people the possibility to buy clothes at low cost. Systems have been developed in receiving countries for sorting and distributing imported used textiles. This is often carried out via the informal sector providing large numbers of jobs.

However, some countries have imposed restrictions on the imports of used textiles. The main reason given is to protect domestic textile industries from competition via cheap imports from Europe and elsewhere. Restrictions most often concern second-hand textiles, but can also apply to new textile products. However, free trade agreements can make it more difficult to impose import restriction on new textile products if a country also wishes to have access to export markets for the domestic production.

Table 4: Overview of possible import restrictions that can apply to used textiles

\begin{tabular}{ll} 
Type of regulation & Description \\
\hline Prohibitions/bans & $\begin{array}{l}\text { These include total bans and prohibitions that demand acquisition of a } \\
\text { special license before import is permitted. The bans can cover all used } \\
\text { textiles or specific groups of products. Furthermore bans can be limited } \\
\text { to items for reuse but not for recycling. Bans on import of used under- } \\
\text { wear are in some countries explained via health concerns } \\
\text { (see below). }\end{array}$ \\
& $\begin{array}{l}\text { These are normal for imports outside of a free area, but the tax level can } \\
\text { vary significantly from o to } 60 \% \text { of the products value or between } 0.2 \text { and }\end{array}$ \\
& $\begin{array}{l}5 \text { USD/kg of used textiles and can have a great impact on imports at these } \\
\text { higher levels }\end{array}$ \\
Tealth certifications & $\begin{array}{l}\text { These normally entail the need for a fumigation certificate or a certificate } \\
\text { for disinfection. Fumigation is normally carried out using a gas-canister } \\
\text { placed in the container prior to shipping. Some argue that fumigation has } \\
\text { no real effect on possible health concerns with the sale of used textiles. }\end{array}$ \\
Bureaucratic walls & $\begin{array}{l}\text { Customs bureaucracy and need for special inspections companies present } \\
\text { additional restrictions to those caused by regulations and taxes above }\end{array}$
\end{tabular}

Rivoli (2014) reports that than more than 30 countries worldwide effectively ban the import of used clothing, either through outright prohibitions (e.g., Botswana, Malawi) or impenetrable bureaucratic walls (e.g., Ethiopia, Morocco).

Table 4 gives an overview of various kinds of restrictions in use. 
We find such restrictions in many regions: Africa, Latin-America, Middle-East and Asia. In this study we have mostly focused on Africa and some other selected countries that are important to Nordic used textile export.

We present some tables below with information mainly drawn from data provided by the Office of Textiles and Apparel (OTEXA) under the US International Trade Administration. ${ }^{6}$ They cover restrictions and regulations for the following import codes:

- 6309.00-Worn clothing and other worn articles.

- 6310.00 - Used or new rags, scrap twine, cordage, rope and cables, and worn-out articles of twine, cordage, rope or cables, of textile materials.

Table 5 includes a selected choice of African countries relevant to this study that have strict import regulations. Table 6 provides similar information for a selection of countries from other regions. The tables has been updated where necessary with additional information from literature and information obtained from market players, such as the Federation for Humana People to People, traders and sorting plants.

http://web.ita.doc.gov/tacgi/eamain.nsf/ff5dd4f75c7795ea8525762500657ba8/801e18gcbcde7edg85257e7600439aea?Open Document 
Table 5: Import restrictions on used textiles in African countries

\begin{tabular}{|c|c|c|c|c|}
\hline Country & Tax tariffs & $\begin{array}{l}\text { Restriction } \\
\text { and/or ban }\end{array}$ & $\begin{array}{l}\text { Fumigation } \\
\text { certificate }\end{array}$ & Other additional \\
\hline South Africa & $\begin{array}{l}60 \% \text { or } 2,500 \text { cents } / \mathrm{kg} 50 \\
\text { cent/unit } \\
20 \%\end{array}$ & $\begin{array}{l}\text { Yes, ban on all ex- } \\
\text { cept donations }\end{array}$ & - & $\begin{array}{l}\text { Permits needed for } \\
\text { used goods not pro- } \\
\text { duced in S-A }\end{array}$ \\
\hline Swaziland & $\begin{array}{l}20-60 \% \text { or } 2,500 \text { cents } / \mathrm{kg} \\
20 \%\end{array}$ & $\begin{array}{l}\text { Yes for all used } \\
\text { textiles and } \\
\text { footwear }\end{array}$ & - & \\
\hline Zimbabwe & $\begin{array}{l}\text { USD } 5 / \mathrm{kg} \\
5-15 \%\end{array}$ & No & - & \\
\hline Botswana & $\begin{array}{l}20-60 \% \text { or } 2,500 \text { cents } / \mathrm{kg} \\
20 \%\end{array}$ & Yes & & \\
\hline Namibia & $20-60 \%$ & Yes & - & Licenses required \\
\hline Malawi & $25 \%$ & Only for underwear & Yes & \\
\hline Zambia & $25 \%$ & Only for underwear & Yes & \\
\hline Ethiopia & $0 \%$ & Yes(?) & - & \\
\hline Kenya & $\begin{array}{l}35 \% \text { or USD } 0.2 / \mathrm{kg} \\
10 \%\end{array}$ & - & Yes & \\
\hline Tanzania & $\begin{array}{l}35 \% \text { or USD } 0.2 / \mathrm{kg} \\
10 \%\end{array}$ & - & Yes & \\
\hline Uganda & $\begin{array}{l}35 \% \text { or USD } 0.2 / \mathrm{kg} \\
10 \%\end{array}$ & - & Yes & \\
\hline Nigeria & $\begin{array}{l}20 \% \\
5-20 \%\end{array}$ & Yes & & \\
\hline Angola & $10 \%$ & - & Yes & \\
\hline Algeria & $30 \%$ & Yes & - & - \\
\hline Morocco & $\begin{array}{l}25 \% \\
2.5 \%\end{array}$ & Yes & - & \\
\hline Cameroon & $30 \%$ & Yes & $\begin{array}{l}\text { Certain certificate } \\
\text { required }\end{array}$ & $\begin{array}{l}\text { No import of worn } \\
\text { undergarments }\end{array}$ \\
\hline
\end{tabular}


Table 6: Import restrictions on used textiles in African countries

\begin{tabular}{|c|c|c|c|c|}
\hline Country & Tax tariffs & Restriction and/or ban & $\begin{array}{l}\text { Fumigation } \\
\text { certificate }\end{array}$ & Other additional \\
\hline Bulgaria & $5.9 \%$ & No real ban & Yes & \\
\hline Turkey & $5.1 \%$ & Yes & & \\
\hline Iran & & Yes & & \\
\hline Bangladesh & $5-25 \%$ & - & Yes & \\
\hline China & $14 \%$ & Yes & & \\
\hline India & $10 \%$ & Yes (for reuse) & & $\begin{array}{l}\text { Units in economic zone can } \\
\text { sell worn clothing in the do- } \\
\text { mestic tariff area. }\end{array}$ \\
\hline Pakistan & $\begin{array}{l}5 \% \\
25 \%\end{array}$ & - & Yes & Special certificates \\
\hline Argentina & & Ban until 1/1/2016 & Yes & \\
\hline Bolivia & $20 \%$ & Yes & $\begin{array}{l}\text { Permit } \\
\text { requested }\end{array}$ & Express permission \\
\hline Brazil & $35 \%$ & & & \\
\hline Costa Rica & $14 \% / 9 \%$ & $\begin{array}{l}\text { Worn undergarments and } \\
\text { footwear prohibited }\end{array}$ & & DR-CAFTA duty free \\
\hline
\end{tabular}

Some additional information on restrictions in selected regions and countries are given below:

- Europe

- There is a tax for import of to Europe on $5.3 \%$ of value. This has an effect on export from Norway into Europe, particularly from Norway to Sweden. The reason for this tax is that Norwegian customs consider used textile to be unknown origin. The tax gives an incentive in the market to set the value lower than the real sales price. There are also several EU-countries that require a certificate of fumigation.

- Ukraine

- There is a regulation in place to prohibit imports of unsorted used textiles and leather products. Ukraine is thereby not a market for original textiles. Sorted 
textiles for reuse are, however, allowed. Human Bridge/Returtex export sorted textiles to Ukraine for use by local church-based charities.

- Turkey

- Turkey has strict import bans, which however don't apply to certain economic zones where import and export of used textiles is allowed. There are textile sorting plants placed within these economic zones.7

- Zimbabwe

- Zimbabwe has a high tax tariff for used textiles that it effectively acts as a ban. Problems with illegal import are reported and there is an on-going discussion about the possibility for deregulation.

- Nigeria

- In Nigeria used textiles are on the list of products that are absolutely forbidden according to the Nigerian Custom Service. The federal government imposed a textile import ban in 2010 to protect local industries.

- However, this has failed due to listed items being smuggled in, badly impacting the nation's economy; Nigeria's small neighbour countries Benin and Togo are on the top-10 list for volumes of imported worn textiles. The factories the Nigerian ban was designed to protect have either become moribund or have completely shut down, rendering thousands jobless.

- The federal government recently delisted textile materials and other items from its import prohibition list in a step towards implementing the Economic Community of West African States (ECOWAS) Common External Tariff (CET). ${ }^{8}$

- India

- India allows import of textile for recycling, but not for reuse. Thus imported textiles must be slashed to ensure they are not reusable. In Panipat north of New Deli there are over a thousand small to medium size factories for recycling these textiles. There is evidence that textiles are prepared here for reuse as well as recycling.

One unwished for consequence of import bans is illegal smuggling of textiles reportedly on a large scale. As noted in the list above, this is reported as a challenge in South

\footnotetext{
${ }^{7}$ http://www.oecd.org/globalrelations/43361618.pdf

${ }^{8}$ Nigeria: Lifting the Ban On Textile Imports, Editorial Daily Trust 24.07.2015. http://allafrica.com/stories/201507241404.html
} 
Africa, Zimbabwe and Nigeria. Textiles are imported to neighbour countries and then illegal distributed over the borders.

In such cases, tax tariffs on worn textiles can be an alternative strategy and can give income to the states, if they are not too high. High tariffs such as those in Zimbabwe, effectively inhibit all legal imports and encourage smuggling. Tariffs based on a percentage of the value can also be a challenge due to the actual value put on the goods. Often a combination of percentage and a minimum fixed tax are in place, where the importer pays the higher of the two.

Donations for aid and humanitarian purposes are not necessary covered by restrictions. An example is South Africa where the ban on imports of used textiles does not cover donations. Donations can also be tax-free.

The landscape of restrictions is developing rapidly. As noted earlier in this report a group of countries in West Africa that are considering increased import restriction. On the other hand some countries are in the process of removing regulations. In general the market situation for export of second hand clothes to Africa is becoming more challenging and future regulation can have great impact on the market balance for used textiles.

\subsubsection{Discussion}

We have seen that many countries place restrictions on imports of used textiles. Even when imports are allowed, bureaucratic barriers are often daunting. Tariffs can be prohibitive, and health certification convoluted. The use by many African countries of pre-shipment inspection (PSI) companies- essentially privately run Customs authorities - has led to charges of overvaluation, corruption, and simple ineptitude.

The barriers to the second-hand textile trade have in large measure been established as a response to complaints by local textile industry. However, doubts can also be raised over whether restrictions on second-hand textiles is an effective means to support domestic textile industries and protect them from global competition. There are several studies that show that the industry has deceased/failed even with import restriction in place. On the other hand, several sources report increased production and export of new textiles in many African countries.

Under Phase 2 we consider whether such restrictions have had the intended effect by looking at South Africa as an example. 


\subsection{Potential for increased traceability}

\subsubsection{Potential for traceability}

Traceability of exported textiles is a key part of the Nordic Textile Commitment, which is being performed, in a trial phase in parallel with this project. The broad overview of the export of used textiles and textile waste presented in Chapter 3 has provided valuable insight in current practice in terms of traceability. It is clear that the export market is complex and includes grey actors and that the interviewed organisations often have a difficult task in finding partners which comply with their requirements/Code of conducts ( $\mathrm{CoCs}$ ) and are willing to report on performance.

Some of the Nordic actors do not follow up on their partners CoCs and some of those who do are finding it increasingly difficult to scale up operations to meet increasing collection volumes. The most apparent environmental risk for receiving countries is inappropriate treatment of waste where this is included along with reusable textiles (in countries importing original). With the lack of sufficient reporting of buyers on what happens with textiles it is difficult to say the extent to which this is happening for Nordic textiles. It is clear that most exporting organisations are seeking long-term cooperation to limit economic and other risks related to short-term contracts.

The market for textile exports from the Nordic countries is diverse both in terms of receiving countries and in terms of the nature of the export. A single exporter can for example have three or more completely different export modes with export for aid; export directly to end distributor in Africa, South America or Asia and export to a commercial sorter within Europe combined with e.g. reimports of sorted textiles.

A basic structure for the different exports is to divide it into:

- Distribution for aid.

- Distribution via second-hand retailers.

- Distribution via professional sorters.

There are rarely clear-cut cases where only one is applicable, but criteria can be set up for these three cases individually and then applied for each exporter seeking certification. 


\subsubsection{Distribution for aid}

Distribution for aid is no longer common practice for Nordic export of used textiles. Earlier there were cases of misplaced textiles piling up close to airports in countries where there simply was no need for the types of garments sent.

For several of the interviewed organisations, distribution for aid is sometimes done on a very small scale as part of other aid activities where the organisation has operations in the receiving country. In these cases the textiles fill a concrete need and a carefully chosen fraction of the mix is sent by demand.

The Finnish Red Cross is still sending for aid as main means of export. In this case the textiles are also more or less ordered by the own organisations operations in the receiving country.

\section{Current best practice}

Traceability for textiles sent as aid is very high and it is easy to follow the textiles down to the end user since it is almost entirely done within the same organisation that is exporting. Textiles are carefully chosen to meet a specific need in disaster relief or long-term aid and are often of a crème-quality that avoids waste in the receiving country.

\subsubsection{Distribution via second-hand retailer}

Exports to sorters which are also active in retail of second-hand textiles are common for sorters in Poland, Bulgaria and the Baltics. This is chosen as a preferred export option by e.g. Myrorna/Fretex, Trasborg and partly by UFF/Humana to ensure long-term capacity and consistent export prices. This gives the possibility to trace textiles down to the end user since $80 \%$ or more of the reusable fraction is sold directly in the sorting country. This is often included in CoCs but with limited follow up for several actors; Fretex, Myrorna, Emmaus Björka and UFF Norway being exceptions. The structure of long-term contracts and short supply chains together create the foundation for traceability but needs enforcement by exporters to work in practice.

\section{Current best practice}

The current best practice includes a $\mathrm{CoC}$ which is enforced by both internal site visits by the exporter and with external audits. Included is also a rather extensive reporting structure to provide reliable statistics and efforts from the exporting organisation to work together with the receiving partner to reduce waste and improve operations. However, the ambitious but complex follow-up processes set limits on rapid increases in collection levels. 


\subsubsection{Distribution via professional sorter}

An increasingly common solution for exports from the Nordic countries is the use of a commercial European sorter, who operates on the global used textile market. This export path gives a clear potential for follow-up on export quality via sample checks to set the price for the Nordic textiles. It, however, makes it impossible to specifically follow the Nordic textiles after being put into the mix. It is, however, possible to trace textiles as part of sorters total mix to distributors. It is also possible to follow quantities and qualities to the different markets, which can be used as rough estimates for reuse and recycling levels. Separate sorting test on sample shipments can document the quality and is a normal procedure at sorting plants.

Beyond the distributors it is generally not possible to follow what happens to the textiles. However, the contracts between commercial sorter and distributors are often long-term to ensure sustainable profits, which should reduce the risk of waste being sent in bales. This would simply be bad for business and make long-term business relationships unlikely.

\section{Current best practice}

Detailed follow-up with current distributors in receiving countries together with qualities, their respective weights for exported textiles and outgoing sorted streams of mixed textiles is the current best practice. This includes division into four quality levels for reuse and a recycling grade and detailed reporting.

\subsubsection{Recommendations for traceability requirements}

A key finding is that current $\mathrm{CoCs}$ are to some extent just a piece of paper since there is in general little follow-up by the exporters. A key requirement for traceability is therefore to have both internal quality systems in place and to have external audits that $\mathrm{CoC}$ criteria is actually fulfilled.

For textiles sent for aid, traceability should be to the end user of the textiles. Since this is mostly done within a single organisation, reporting should be done regularly to ensure that exported aid meets an actual need.

For exports to sorters with primarily their own second hand retail, requirements should be to follow textiles to end user sales including actual reuse, recycling and waste management. For exports to a commercial sorter it should be possible to give end country distribution for reuse and recycling together with the commercial sorter's waste management. Sample checks should be done by the commercial sorter to see the actual reuse and recycling rate for a number of distributors to provide a fixed reduction of accounted reuse and recycling for the exporter. 


\section{PHASE 2-Impact of Exports}

Phase 2 comprises a deeper investigation into the fate of used textiles in three selected countries, and an analysis of likely socio-, economic- and environmental impacts, benefits and risks. Under this phase we aim to answer the following:

- How are used textiles imported to the three recipient countries subsequently treated? What share is reused and what share directly becomes waste and how is this waste treated?

- What are the likely consequences (positive and negative), of imports of used textiles and textile waste on the environment, health and economy of the three recipient countries? What is the impact on the local textile industry and employment in the beneficiary countries?

- What is the purpose of import restrictions in countries? Have import restrictions already in place had the desired effect?

\subsection{Methodology}

\subsubsection{Selection of countries for site visits}

The study countries need to be selected carefully to ensure findings that are as illustrative as possible of the full pathways for Nordic used textile exports. As mapped out under Phase 1 the typical pathway for used Nordic textiles is as follows:

- The majority of exported textiles have their first stop within the EU, mostly Eastern Europe, where they are sorted into various grades.

- The highest quality grades are mostly sold in Eastern Europe, second grade and tropical quality is exported for reuse in Africa (and the Middle East) while the lowest grades are exported to Asia for reuse and recycling. Some recycling also occurs in Europe.

- Exports to the African continent are exclusively reusable textiles for resale (small amount donated). 
On this basis and with regard to the Phase 2 research questions above it was decided to choose:

- One country which sorts Nordic "original" and has a second-hand retail market.

- One African (or Middle Eastern country) country where second grade is sent for reuse and which has a local textile industry.

- One country in Asia, or elsewhere, that receives the lowest grade used textiles for reuse and recycling.

- At least one country where Nordic used textiles represent a significant share of total imports of used textiles.

- Countries where we have good contacts via Nordic operators, embassies or otherwise.

- Countries with reasonable potential for supplementary statistical data.

- Countries where English is well-used or the official language.

We screened six countries against these criteria. This resulted in recommendations for studies in Poland, Pakistan and Malawi, which were accepted by the Nordic Waste Group. The reasons and the main focus country studies are given in Box 2.1.

\section{Box 2.1: Country selection and main focus}

Poland

The largest importer of Nordic original at over 17,500 tonnes. $27 \%$ of Poland's imports of used textiles are from the Nordic region. We have good contacts via both Frelsens Hær and Fretex International and Emmaus Björke Economic and waste treatment statistics are good being accessible via Eurostat amongst other sources. The country has a large textile industry.

Key issues to investigate

Number and condition of jobs in sorting and secondhand. Treatment of textile and non-textile waste arising from sorting. Evidence of negative impacts on textile manufacturing.

Pakistan

The largest non-EU importer (direct and indirect via intermediaries) of Nordic used textiles (over 5,000 tonnes). A large part of the imports are low-grade textiles for reuse and recycling mostly imported to segregated economic zone $s$ with special rules and restrictions on import exchanges with the remainder of the country. New textile production is one of the largest economic sectors. We have good contacts there via Fretex Internaitonal who have carried out third party audits of their main buyers. Economic and waste treatment statistics are not so good, however. 
Key issues to investigate

Number and condition of jobs and economy in recycling of rags and in reuse. Evidence of negative impacts on textile manufacturing. Waste treatment of any residual waste. Products offset by reused and recycled textiles.

Malawi

Malawi imports at least 1,400 tonnes of used textiles from Nordic countries for reuse with reportedly no imports of textile waste. There are no import restrictions. We have good contacts via Humana who are also carrying out an investigation of impacts. Access to economic data on textile manufacturing is limited online but we believe that we can get hold of some data on this.

Key issues to investigate

Number and condition of jobs in secondhand. Evidence of negative impacts on textile manufacturing. Evidence of smuggling to nearby countries with restrictions on. Whether the no-waste claim is realistic.

In addition, in order to investigate whether strong import restrictions on second-hand textiles we also chose to briefly investigate progress of the South African textile industry in comparison to the Malawian. South Africa has a strict ban on imports of nondonated used textiles.

\subsubsection{Data Collection}

Country visits were carried out in Poland and Malawi/South Africa. Due to security issues in Pakistan visits here were not possible. Therefore, the team had to rely upon interviews with Nordic textile collection organisations with good connections in the country. A portion of the budget was also set aside to pay for local agents (employees in the Danish Embassy) to carry out investigations on the ground.

Where possible, interviews were carried out with:

- Nordic organisations exporting to the case country

- Sorters/wholesalers/recyclers/second-hand retailers

- $\quad$ Stakeholders from the regular textile industry

- Civil servants from economic and environment ministries

Interviews were guided by the questions in Box 2.2. Only the relevant questions were asked of each interviewee. 
Contacts with Nordic collection and exporting organisations were of key importance since they had regular contact with buyers in the country, in some cases over a number of years. The organisations with which the team had contact have strong levels of traceability implemented via codes of conduct that their buyers have to live up to. This improved data collection potential.

On the other hand, the fact that much of the data was gained via local companies living up to codes of conduct, risked biasing the results of the assessment towards positive social and environmental impacts, than if the importer was a third party with no social or environmental objectives.

With this in mind, the local companies were also asked about conditions in the rest of the industry. Furthermore, information was obtained on CoC criteria that the buyers had not been able to live up to during the first audits. The Nordic charity organisations with CoC's tend to work with companies to enable them to meet demands, rather than screening potential partners via demand criteria.

\section{Box 2.2: Questions for structured interviews}

- What types of used textiles are imported to the country and which organisations are involved? (sorted or unsorted, types of products, fibres etc.).

- For how long approximately have such imports been arriving and how have volumes been developing?

- Which countries are the textiles being imported from?

- What is the normal price for main qualities delivered (USD/kg)?

The above questions supplemented with official import data

- What share does your organisation have in the total?

- Who are the main customers for the imported textiles and what information is available about the value chain for used textiles after being received at the first storage/warehouse.

- Is any sorting carried out locally? If so, what types of fractions are used and for what purposes, and is there any waste left over?

- What is the main waste treatment scenario for waste from sorting and also for mixed household waste?

- Approximate collection rates for household waste.

○ Landfill/incineration/other.

Question 8 supplemented by information from waste authorities

- What happens to the various fractions of used textiles that arrive? (i.e. resold for reuse, donated as relief, recycled, other waste treatment) and what is the share of each?

- Where are used textiles sold, what is the typical price of resold products and how does this compare to prices of new similar products?

- Is their evidence that the sale/donation of used items offsets new items?

- What kind of recycling activities are there, what are the products, what is their price and 
who are they sold to, and how many people are employed? (informal/formal).

- Approximately how many people are working along the chain from arrival of used textiles in the country to point of sale? (formal/informal) Ideally per tonne of used textile imports.

- Is there or has there been in the past a local textiles industry? If yes please give trends in:
- Products?
- Employees?
- Turnover?

Question 11 supplemented by figures from dept. of economy if available

- How has the development of imports of new textiles from Asia and elsewhere been for the same period in amounts, import value and employees in the import and retail companies?

Above will be supplemented by official import data

- If there are import restrictions, what was the purpose of the restrictions and have they had the intended effect?

- Do the restrictions take the form of bans, or import duties or both?

- If duties - what is the value of these and does it differ for used clothes and rags? what happens to the revenue?

- Has smuggling/illegal cross-border trade arisen as a result of the restrictions?

- Are loopholes being used?

- Does your organisation have environmental/social objectives in the country and do used textiles play a role in this? If yes:

- How have these been implemented with respect to textiles?

- What impacts have been recorded?

Please describe the overall positive and negative environmental, social and economic effects that you feel that the imported used textiles have had in the country.

As identified in Box 2.2, where possible data gathered during interviews was supplemented with information gathered via official statistics and reports, both from local and international sources. Other literature was also used including reports from NGOs, research reports by universities etc. Specific sources of data are outline in the country reports provided in Appendices $\mathrm{C}$ to $\mathrm{E}$. 


\subsection{The Economics of Used textiles}

The three country studies confirmed the general picture gained under Phase 1 of the project and described in the first part of this report, but added some more detail.

The flows of used textiles from Nordic countries (as with used textiles in general) tend to follow the market according to price. Flows respond rapidly to changing supply and demand globally.

The flow of textiles can be viewed as a cascade of quality from countries with high incomes to countries with increasingly lower incomes. The cream remains in Europe, mostly in Eastern Europe, often in the same countries where there are sorting operations. Quality grades A and B and tropical quality tends to be exported to Africa and the Middle East (but also in Eastern Europe and Latin America). The lowest grades are exported to Asia for reuse and recycling. Figure 15 gives a typical breakdown for the quality and eventual fate of a lorry-load of original arriving at a sorting facility.

Figure 15: Typical fate and price/kg for post-sorted fractions of a lorry load of original

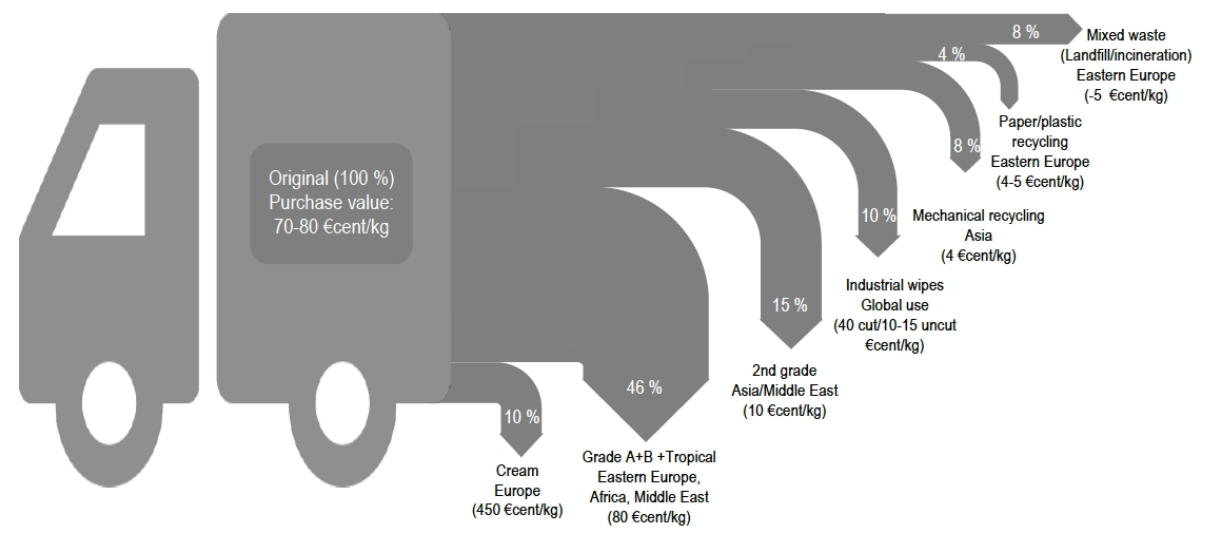

Source: Own making.

The richer a country is, the less inclined the population is to buy lower quality secondhand. As global economies develop the used textile cascade shifts its course. For example, whereas at the beginning of the millennium in Poland $80 \%$ of the textiles that were exported there for sorting, were sold on the domestic market, but according to some reporters this figure may have dropped to $40 \%$ or lower as Polish citizens became wealthier. The textiles that once would have been consumed there are now exported to Ukraine, Romania or further afield where they are still in demand. 
The Polish study suggests that the figure in Table 3 and Figure 14 for estimated textiles staying in Poland may be overestimated. Fretex International has not been able, however, to give us revised figures to allow us to adjust the figures in Table 3 as a result.

As well as affecting ultimate destination, economic development has also affected price. Until a few years ago there was a high demand for used textiles on the global market and a lack of supply to meet it. More recently, as a result of economic growth, the situation has reversed. There is now a glut in supply in Europe but a drop in domestic demand. Wholesalers also reported that at the end of the quality cascade, in Pakistan for example, buyers are also becoming more selective in what they accept. These trends have led to an overall drop in prices.

Contrary to expectations, this drop in prices has not had the effect of reducing reuse and especially recycling activities, quite the contrary. A decade ago the high prices meant that sorters/wholesalers could make a profit just by selling the cream and second grade and the rest could be disposed of in municipal waste. The fall in prices for second-hand means that wholesalers/sorters need to squeeze every cent out of the original they receive from collection organisations (or the raw material as they call it).

Figure 16 presents the economics for a typical sorter in Poland. The sorter must pay between 70 Eurocents and 80 Eurocents $/ \mathrm{kg}$ for original, but the total sellable valve of a $\mathrm{kg}$ of original after sorting is around 85 Eurocents The 5-15 Eurocent margin must pay for transport from the collector, payback on investments in the sorting facility, rent of land/space, use of energy for machinery and most importantly, all sorting staff. This latter is the highest cost factor. If the sorter only sold the cream and Grade $A$ and $B$, the margins could reduce to as low as 1 Eurocent. Therefore although he makes very little money from the lower grades and textiles for recycling compared to the cream, selling these are crucial to increasing his margin.

This includes not just textiles but also the non-textiles articles found in the original. One example was seen in Poland of a worker in a sorting facility whose job is to make pairs from similar single shoes for reuse in Pakistan. Even single shoes without a match can find a customer in Asia. 
Figure 16: The necessity of squeezing every cent from used textiles: purchase price of $1 \mathrm{~kg}$ of "original" and sales value of its contents

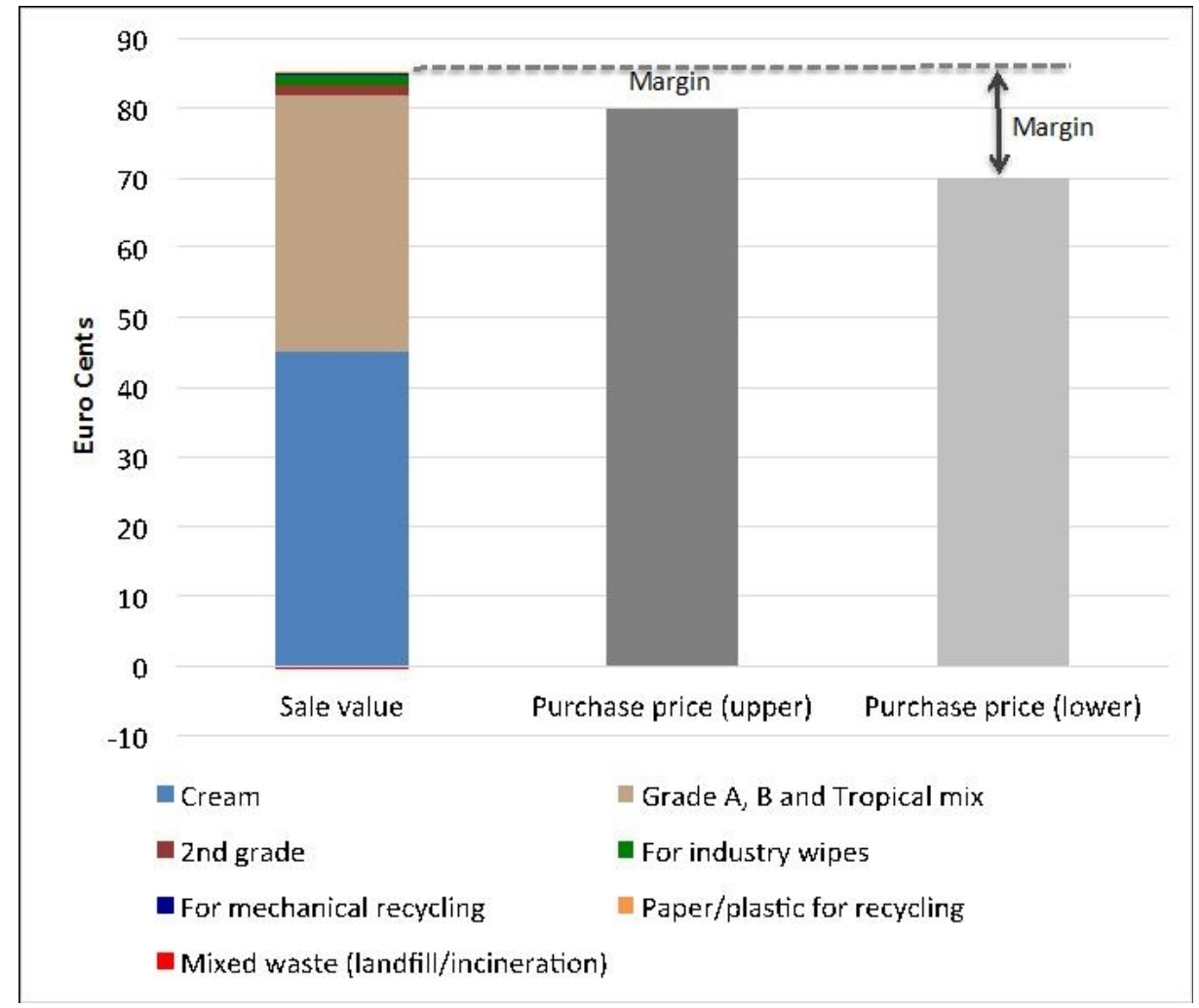

The lower wholesale price for used textiles has also had an effect on the diversity of the second-hand sector. In Poland, narrow margins mean that only the more effective and established sorters and wholesalers have survived; overall numbers of sorters, wholesalers and retailers have diminished significantly.

While narrow margins have ensured that all parts of the exported original are reused or recycled, thus reducing environmental risk, the same narrow margins can also act as a driver in pressing down wages of people working in the sector. Whether this happens or not depends on wage policy in receiving countries, the levels to which these are enforced and also whether the employers or their clients have CSR policy, codes of conduct etc. These issues are examined further in the socio-economic assessment.

The end fate of textiles reported in the study countries gives a very similar picture when the jigsaw puzzle pieces are fixed together to the overview already received 
from Myrorna/Fretex and Humana/UFF under Phase 1. Since the end fate of textiles is guided by economics rather than by codes of conducts we can assume that the high reuse and recycling shares reported by these organisations are typical for the exports as a whole. Table 7 provides an estimate of shares and regional destinations for unsorted and pre-sorted exports from Nordic countries.

Table 7: Estimated fate of exported Nordic textiles

\begin{tabular}{lllllll} 
& Reuse & & \multicolumn{3}{c}{ Recycling } & Waste \\
& $\begin{array}{l}\text { Cream } \\
\text { (mostly } \\
\text { Eastern } \\
\text { Europe) }\end{array}$ & $\begin{array}{l}\text { Grade A and B } \\
\text { (Africa/ Eastern } \\
\text { Europe/Middle } \\
\text { East) }\end{array}$ & $\begin{array}{l}\text { Second } \\
\text { grade } \\
\text { (Asia and } \\
\text { Middle } \\
\text { East) }\end{array}$ & $\begin{array}{l}\text { Industrial } \\
\text { wipes } \\
\text { (Global) }\end{array}$ & $\begin{array}{l}\text { Mechanical } \\
\text { recycling } \\
\text { (mostly Asia) }\end{array}$ & $\begin{array}{l}\text { Landfill and } \\
\text { other } \\
\text { (incl. cement } \\
\text { furnaces) and } \\
\text { other }\end{array}$ \\
$\begin{array}{l}\text { Exports of } \\
\text { "original" }\end{array}$ & $10 \%$ & $46 \%$ & $15 \%$ & $10 \%$ & $8 \%$ & $\begin{array}{l}11 \% \text { (including } \\
3 \% \text { non-textile } \\
\text { mostly recycled) }\end{array}$ \\
$\begin{array}{l}\text { Exports of } \\
\text { pre-sorted } \\
\text { textiles* }\end{array}$ & - & $53 \%$ & $17 \%$ & $11 \%$ & $9 \%$ & $10 \%$ \\
\hline
\end{tabular}

Note: * This mostly means that the cream and non-textile waste has been removed. The remainder is for the most part exported to Eastern Europe for sorting. It is assumed that the distribution of this is the same as for original (minus cream and non-textile waste)

\subsection{Environmental impacts and benefits}

A key assumption in the Nordic Green Growth textiles projects has been that, when viewed globally and over the full lifecycle, increasing reuse and recycling of used textiles will reduce the total environmental impact associated with the Nordic demand for textiles.

This is because it is assumed that reuse offsets a demand for new textiles, whether the reuse occurs in the Nordic countries or elsewhere, and thus offset the high environmental impacts caused by the production of new textiles. Similarly, recycling of textiles into other products will offset the extraction of virgin materials for these products (Schmidt et al., 2016). However, this may be offset by environmental impacts caused during the transport, sorting and reuse and recycling processes.

The first aim of this environmental assessment is to estimate these effects and estimate the net global environmental impacts/benefits resulting from the export of Nordic used textiles.

There is also a local perspective with respect to environmental impacts that should be viewed separately from the global effects. Is the export of used textiles causing envi- 
ronmental impacts in the receiving countries? The focus here is on the risk of exporting waste to countries without the proper systems in place to treat it responsibly.

\subsubsection{Local Environmental Risks}

Waste from sorting

As identified under Phase 1 - around three quarters of textiles exports from the Nordic countries are largely unsorted original. Most collectors do carry out some basic filtering to remove larger pieces of non-textile waste from containers. The aim of this is to ensure that the exports don't run into problems with customs services under the EU Shipment of Waste Regulations and other regulations implementing the Basel Convention (see Phase 1).

Figure 17: Why opening bags of "original" prior to export is taboo: composition by weight and composition by value of original

\section{Composition by weight}

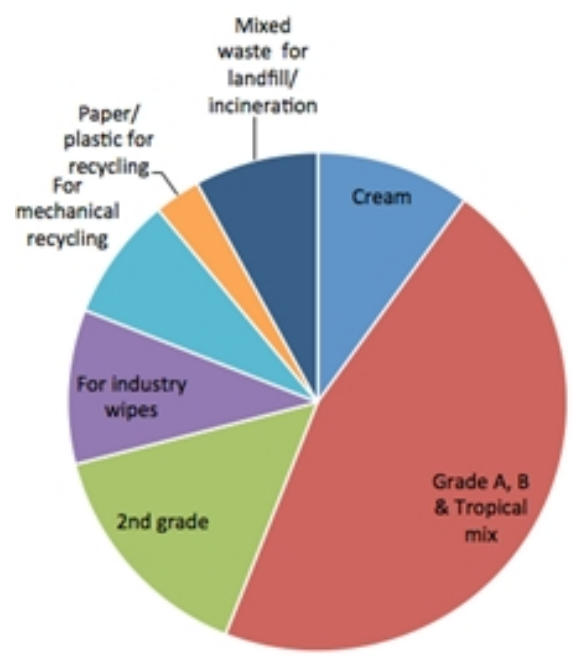

Composition by sellable value

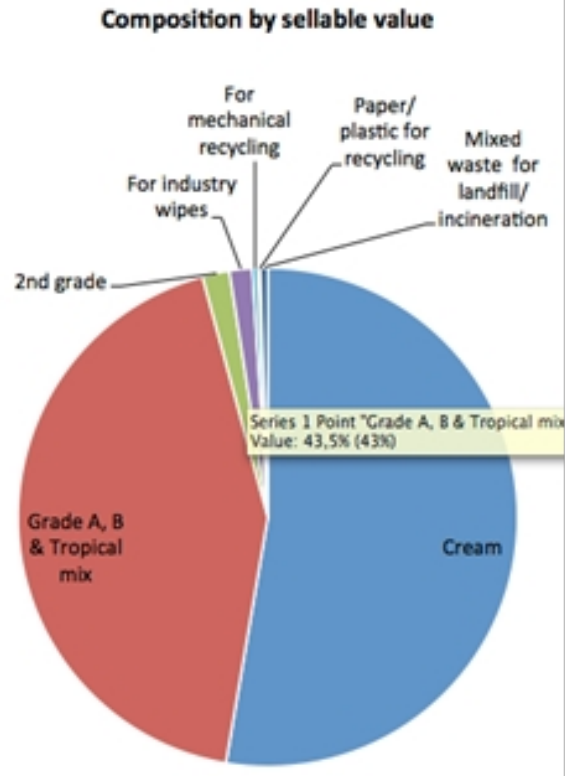

As a rule pre-sorting of original only comprises removal of any non-textile (and perhaps some obvious textile) waste that lies outside the bags that clothing has been donated in. Exporters tend not to open bags to remove waste inside. This is for fear of being accused by buyers of filtering off the "cream" before exporting. The cream represents only $10 \%$ of the weight of the original, but represents $53 \%$ of its value (see 
Figure 17). Therefore, skimming off a few choice items can drastically reduce the value for the buyer and opening of bags is taboo within the branch (see Appendix C).

As a result even partially pre-sorted original contains an element of waste - typically around $6-10 \%$ of volume. The 13 largest collectors alone exported 51,000 tonnes of original in 2014, which could include up to 5,000 tonnes of textile and non-textile waste.

$99 \%$ of original is exported to countries within the EU for sorting, mostly in eastlying Member States. Since waste treatment in the EU is guided by strong regulations with assistance for implementation it can be assumed that any waste resulting from sorting processes in EU Member States will be treated responsibly.

This assumption was confirmed by the Polish country study. As described earlier, value is squeezed from every part of the original as far as possible, however low the quality. This is also true of the waste. Since waste treatment typically costs the sorter around 5 Eurocents per $\mathrm{kg}$ the waste is sorted into sellable fractions as far as possible.

Non-textile bric-a-brac like kitchenware and toys are sorted out for resale either in Poland or for export to Eastern Europe. Plastic bags and paper/cardboard are separated and sold for recycling for approx. 3-4 Eurocents $/ \mathrm{kg}$. Hard plastic is also typically separated and sold for recycling for around 6 Eurocents. The very small fraction of remaining non-recyclable waste is removed by private or municipal waste companies who carry out further recycling as far as possible. This is enabled by the fact that the waste is dry and not contaminated for example by kitchen waste.

Similarly all textiles are used as far as possible. That which is not fit for reuse is cut into industry wipes or exported for recycling. Only mouldy or otherwise contaminated textiles are not recycled and are removed by local waste companies, although one sorter sends his to a cement factory for incineration where it replaces fossil fuels. This is slightly cheaper for him than other mixed waste collection by private companies/municipality. Otherwise it is expected that the textile waste is landfilled; $75 \%$ of municipal waste is still landfilled in Poland, although incineration with energy use is growing rapidly in the country. All Polish landfills had conformed to EU standards by 2012 (Fischer 2013).

Due to the economic conditions under which sorters operate we presume that extraction of all valuable components and subsequent landfill of remaining waste is typical for sorters in the EU.

Some of the sorting countries in the EU are further behind Poland in their implementation of the Waste Framework Directives. $98 \%$ and $95 \%$ of municipal waste is landfilled in Bulgaria and Romania respectively and there remain landfills in both countries that do not comply with minimum EU standards (Kallay, 2013; Almasi, 
2013). These are being rapidly phased out though and by 2017 all landfills in use are expected to be compliant. ${ }^{9}$

Proper treatment of the non-recyclable/non-reusable fractions is a cost factor for sorters, which could encourage fly-tipping of waste. At least in Poland, correct treatment of waste is strongly enforced and fly-tipping thought to be rare. Illegal waste tips are found in Romania, but these are mostly the result of lack of waste collection services in rural areas prior to entry into the $\mathrm{EU}$ and are now being removed. ${ }^{10}$ The risk of fly-tipping by sorting companies is assumed to be low and falling in EU countries as regulation and control is improved.

\section{Waste beyond the EU}

All textiles exported to countries further afield has undergone sorting and certainly non-textile waste has been completely removed. Detailed sorting is typically conducted by experienced staff and it is, therefore, expected that the non-reusable or recyclable content in re-exported textiles is limited.

The Malawi country study found this to be the case for textiles imported from Europe. According to one of the main importing charities less than $1 \%$ of the imported textiles that undergo further sorting for retail shops or market-place sellers, are rejected. These rejects are used for clothing repairs or cut into industry wipes. Similarly to practice in Eastern Europe second-hand retail shops in Malawi progressively reduce prices for clothing in the shops over the space over a one or two-week period until a fresh load arrives. This maximises sales, ensuring that there are minimal non-sold goods. Unsold goods will again be used for repairs e.g. by roadside seamstresses in the main cities (see Appendix B).

It should be noted that minimisation of textile waste is also dependent on a good long-term relationship between importer and seller in order to ensure that what is being exported to Africa in bales matches what can be sold on the market. It tends to take a few consignments of exports between a European exporter and an African wholesaler before the grades have been completely matched to needs (Abimbola, 2012). Thus long-term relationships are key in this trade.

Again it is economics that is the main driver for ensuring minimal waste. Since all textiles have some value in Malawi, whether reusable or not, almost none of the textiles imported from Europe are reused or recycled. The few items that aren't will tend

\footnotetext{
${ }^{9}$ http://eimpack.ist.utl.pt/docs/WASTE\%20SECTOR\%2oIN\%20ROMANIA.pdf

${ }^{10} \mathrm{http}: / /$ www.academia.edu/6331450/Quantitative_assessment_method_of_illegal_dumping_\%C_\%AEn_small_rivers._Cas e_study_Neamt_County_Romania
} 
to be picked out and recycled in some form by the many waste pickers operating at city dumps (see Appendix B). ${ }^{11}$

Due to similar economic conditions elsewhere, we expect that the practices in Malawi will be largely similar to those in other parts of sub-Saharan Africa that receive imports of used textiles from Europe. i.e. insignificant levels of waste arising.

As reported under Phase 1, almost all separately collected Nordic textiles are sold to raise money either for charitable works or private profit. Direct donations of textiles to crisis areas are much more rare than they were a few decades ago. Thus, reported situations from that period where large amounts of donated clothing ended unwanted on airport runways in receiving countries no longer happens today.

The previous section on waste from sorting described the typical scenario of detailed sorting occurring in Eastern Europe. However, some detailed sorting of presorted Nordic textiles also occurs elsewhere. Fretex International, for example, exports some pre-sorted textiles to Pakistan for further sorting in Special Economic Zones (see Appendix D). Cream and non-textile waste have been removed prior to export.

Fretex International's buyer in Pakistan reports that $100 \%$ of the received textiles are sold in some or other form. No less than $57 \%$ is recycled: $36 \%$ is exported either as cut industrial wipes for the global market or slashed textiles exported to India for mechanical recycling; $21 \%$ is mechanically recycled domestically. Fortunately, while there are limits on reusable textiles that enter Pakistan from the special economic zones there are no limits on textiles intended for recycling. The economic zone lies close enough to potential users of recovered textile threads from the recycling processes, that it makes more economic sense to recycle than to dispose of as waste. Especially since waste in the economic zones is tightly controlled and there is a cost for disposing of it (see Appendix D).

As described earlier Nordic textiles can also arrive Pakistan and other parts of Asia via sorting facilities in Eastern Europe. Here it is low grade textiles, and textiles intended for mechanical recycling that are imported. Again economics dictate that these are reused or recycled as far as possible with very little, if any waste.

\section{Eco-efficiency of plants}

It wasn't possible to gather specific information on the efficiency or emissions of sorting and recycling plants in either Eastern Europe or in Pakistan.

In general sorting plants have no direct emissions either to water or air. There is machinery - conveyor belts, bailing machines and forklifts - but the electricity these

\footnotetext{
${ }^{11}$ http://stud.epsilon.slu.se/7550/1/barre_j_150107.pdf
} 
use is not significant compared to energy savings from offset production of clothing and other resources (see global impacts section).

\subsubsection{Global net environmental impacts and benefits}

\section{Methods and assumptions}

The key question for this assessment is (see also Box 2.3):

- Does the export of used textiles from Nordic countries give an overall environmental benefit.

To provide a broad answer to this question we use a life cycle assessment (LCA) model developed under a recent project for the Nordic Waste Group (NAG). The model was developed to compare the impacts/benefits of various treatment options for discarded used textiles in Nordic countries.

\section{Box 2.3: A non-export scenario}

A second question of considerable strategic interest would be: Is the environmental benefit greater or lesser than if the textiles had remained in, and been treated in the Nordic countries?

In order to answer this second question we would have to model a realistic scenario for what would happen to the textiles if, for example, an export ban was put in place.

Would charities get rid of their containers and only collect the $10 \%$ "cream" that they can resell domestically in their own shops? Would the rest be thrown out by households into mixed waste and incinerated? Or would technology be found that could make recycling feasible and economically viable in the Nordic countries? Would means be found to encourage Nordic consumers to purchase lower grade second hand?

These exciting questions are beyond the scope of this project and are being investigated by others e.g. the Mistra Future Fashion programme in Sweden. We will therefore not attempt to answer this additional question here.

Treatment scenarios including reuse in Nordic countries, reuse in the rest of the world, various recycling options and incineration with energy recovery were developed for 1 tonne of; pure cotton, pure polyester, pure wool and an average Nordic mix of fibres (Schmidt et al. 2016).

For our assessment here, we use the same model to model the various pathways of the approximately 75,000 tonnes of used textiles that are exported annually from the Nordic countries, and add up the impacts and benefits of these pathways. The im- 
pacts arise from the various transport stages of the exported textiles, energy used in sorting and recycling plants and, for reused textiles, the final end of life stages. Benefits arise from offset products and materials.

The pathways are roughly mapped using the data gained under Phase 1 , updated with information generated during country studies in Phase 2. The shares given in Table 7 are multiplied by the quantities given in Table 1 and finally scaled up to the 75,000 tonnes of total exports. The pathways are broadly shown in Figure 18 at a crude level but sufficient for the purposes of the LCA model.

Figure 18: Simplified view of flows of used textiles for use in the LCA model

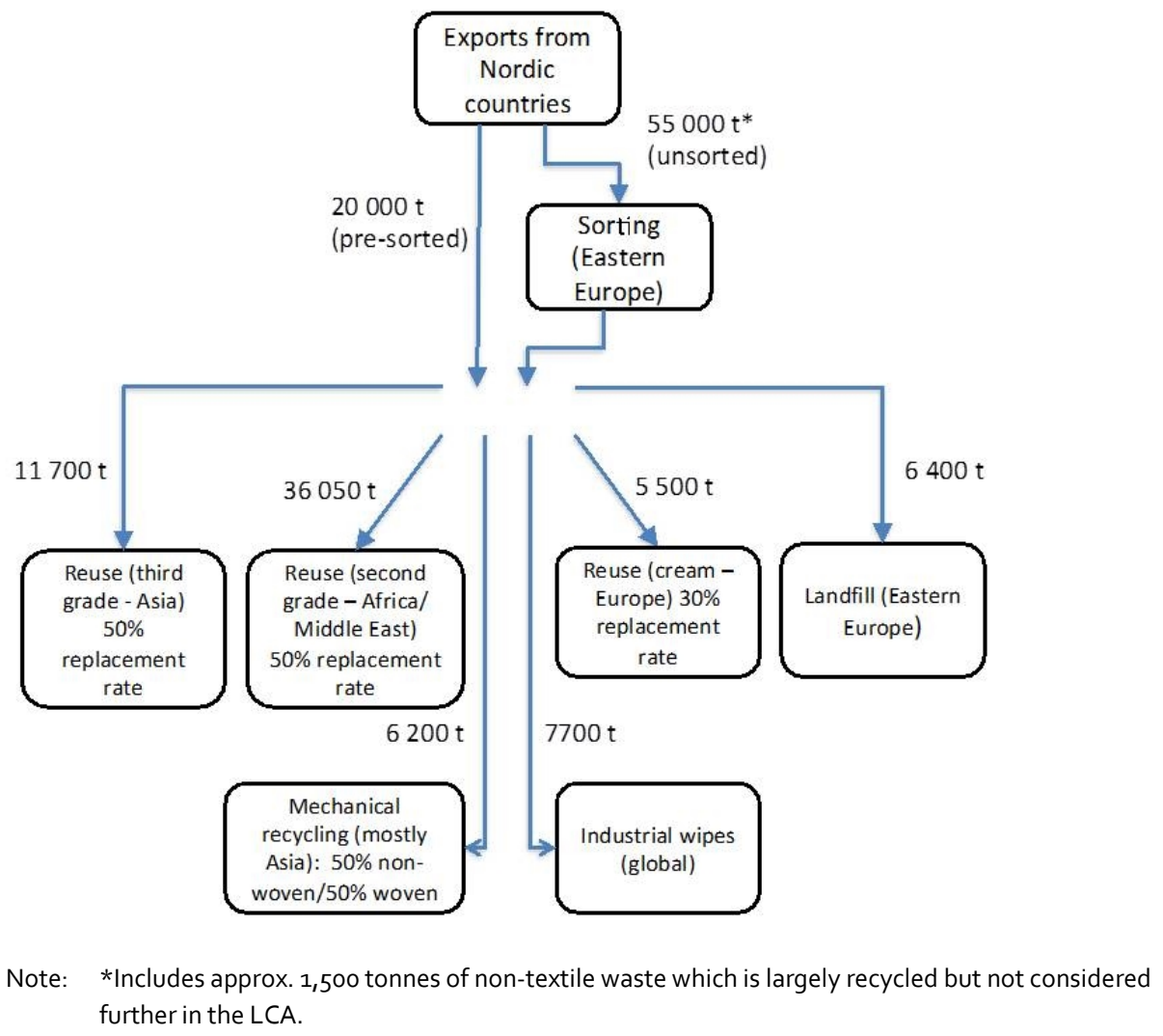

The budget for this project does not allow a detailed update of the LCA model to include each transport leg to various destinations mapped in Phase 1. Instead the standard distances for rest of the world (ROW) treatment that was developed under the LCA project are used. One of the results of that project was that transport stag- 
es contributed in a relatively insignificant way to overall impacts of the discarded textiles (Schmidt et al., 2016).

Moreover, we do not have data to model individual recycling processes in each country. Instead the standard recycling models developed in Schmidt et al. (2016) are applied where appropriate.

A very important variable in the model is the substitution rate assumed for reused textiles. This is the degree to which a reused item replaces the purchase (and thus the production) of an equivalent new textile product. This is an important factor in determining overall benefits; the higher the replacement rate, the higher the environmental benefits of reuse.

As described in Schmidt et al. (2016), there is very limited data available on replacement rates. Farrant (2008) estimated displacement rates of $60 \%$ in Sweden/Denmark and $75 \%$ in Estonia. A more recent study by WRAP (2013) showed displacement rates between regions in the UK of $11 \%$ to $52 \%$ with an average of $29 \%$. Both studies were based on statement of intent.

Displacement rates depend on a wide range of factors. A high substitution factor is expected where a purchase is a result of a concrete need and/or where the secondhand product is relatively expensive for the purchaser. A low substitution rate could be expected where the purchase is spontaneous and/or the price of the second-hand product is perceived to be insignificant.

The budget for country studies under this current project did not allow investigations of substitution rates for reuse. Therefore, we made some (conservative) assumptions. We assume a $30 \%$ displacement rate for the high quality cream that is sold in Eastern Europe. This agrees with the most conservative rate estimated in studies.

The situation for second-hand sold in Africa and Asia is somewhat different. For a large part of the population purchase of clothing is likely to be of necessity rather than spontaneous or frivolous and represents a large cost to the buyer. Moreover, secondhand is often the better choice than new Asian imports both in price and quality. These factors would suggest a high substitution rate in Africa and Asia. Here we make a conservative assumption of $50 \%$.

Where substitutions of less than $100 \%$ are used in the model for reuse, the model must also include end-of-life processes for the textiles reused in receiving countries once they no longer are fit for reuse (see Box 2.4 for an explanation of this). In that case, treatment methods of mixed household waste should be used. 


\section{Box 2.4: Substitution factors and end-of-life}

Let's imagine a dress is exported from Sweden to Poland as part of a mixed load for sorting. It's sorted in Poland and then is re-exported to Malawi for reuse. It is sold to a merchant who has a market stall and sells it to Mrs. Tgoba. Mrs. Tgoba uses it for a few years until it gets worn out. Then she uses it as a kitchen rag for a while and finally when it can no longer be used in any form it will end as waste, perhaps on an open landfill or burnt on an open fire.

A key question for Life Cycle Assessment (LCA) practitioners is whether the burning of the dress in the open fire or throwing in an open landfill should be included in the LCA? The answer depends on whether, if Mrs. Tgoba hadn't been able to buy the used dress, she would have bought a new one instead.

If the answer is yes, then we don't need to consider the eventual end-of-life of that dress, since the new dress it replaces would also have an identical end-of-life. There is no additional waste caused by the imported used dress. But if the dress doesn't offset the purchase of a new dress then the endof-life ought to be included in the LCA. If the used dress offsets half a new dress (i.e. $50 \%$ replacement rate) then half the end-of-life impacts should be included in the LCA.

As described under the previous section on local environmental risks, most household waste in Eastern Europe ends in controlled landfills. We use a standard controlled European landfill process in the LCA for the cream that is resold in Europe.

Modelling end-of-life of textiles exported to Africa, Middle East and Pakistan for reuse is more problematic. A large part of household waste is simply not collected in Malawi and this may be typical of Sub-Saharan Africa (see Appendix B). We don't have any information on what happens to the uncollected waste. It may be burnt on open fires, scavenged for use in all sorts of functions, or just left on illegal tips. That which is collected by local government ends in open landfill. The situation is similar in Pakistan. Less than $50 \%$ of household waste is collected and even then it is disposed at dumpsites or roadsides since there are hardly any sanitary landfills in Pakistan (see Appendix D).

For the purposes of the model we assume that in developing countries, $50 \%$ of reused Nordic textiles eventually end in open landfill and $50 \%$ end on open fires. We don't have LCA processes for such end-of-life scenarios. We therefore use a LCA process for a common landfill and a common incineration process with modifications.

The landfill process was modified to assume release of all gas emissions to air rather than being captured and used as biogas. Similarly we modified the incineration process so that energy output from the burning of the textiles is not credited. However, we weren't able to take account of other emissions to air from an open fire that would otherwise be captured by a modern incinerator, nor emissions from uncon- 
trolled waste dumps to the surrounding environment. The main assumptions used in the LCA model are summarised in Table 8.

Table 8: Key assumptions used in the LCA modelling for estimating global net impacts/benefits of Nordic exports

\begin{tabular}{|c|c|c|c|c|c|}
\hline & $\begin{array}{r}\text { Weight } \\
\text { (tonnes) }\end{array}$ & $\begin{array}{r}\text { Replacement of } \\
\text { new products }\end{array}$ & Fibre type & $\begin{array}{l}\text { Final end-of-life for } \\
\text { reused textiles }\end{array}$ & Transport following export \\
\hline $\begin{array}{l}\text { Reuse (cream } \\
\text { Europe) }\end{array}$ & 5,500 & $30 \%$ & Nordic mix* & $\begin{array}{l}\text { Standard controlled } \\
\text { European landfill }\end{array}$ & $500 \mathrm{~km}$ truck to user \\
\hline $\begin{array}{l}\text { Reuse (second } \\
\text { grade - Africa/ } \\
\text { Middle East) }\end{array}$ & 36,050 & $50 \%$ & Nordic mix* & $\begin{array}{l}\text { Burnt on open fires, } \\
\text { illegal tips and open } \\
\text { landfill. }\end{array}$ & $\begin{array}{l}\text { 6ookm from sorting to harbour } \\
8,000 \mathrm{~km} \text { ship to Asia } 2,000 \mathrm{~km} \\
\text { truck to user }\end{array}$ \\
\hline $\begin{array}{l}\text { Reuse (third } \\
\text { grade - Asia) }\end{array}$ & 11,700 & $50 \%$ & Nordic mix* & $\begin{array}{l}\text { Burnt on open fires, } \\
\text { illegal tips and open } \\
\text { landfill. }\end{array}$ & $\begin{array}{l}\text { 6ookm from sorting to harbour } \\
17,000 \mathrm{~km} \text { ship to Asia } 1,000 \mathrm{~km} \\
\text { truck to user }\end{array}$ \\
\hline $\begin{array}{l}\text { Mechanical } \\
\text { recycling (most- } \\
\text { ly Asia) }\end{array}$ & 6,200 & $100 \%$ & $\begin{array}{l}\text { Cotton and } \\
\text { wool }\end{array}$ & $\mathrm{n} / \mathrm{a}$ & $\begin{array}{l}\text { 6ookm from sorting to harbour } \\
17,000 \mathrm{~km} \text { ship to Asia 1,000km } \\
\text { truck to user }\end{array}$ \\
\hline $\begin{array}{l}\text { Industrial wipes } \\
\text { (global) }\end{array}$ & 7,700 & $100 \%$ & $\begin{array}{l}\text { Nordic mix* } \\
\text { without wool }\end{array}$ & $\mathrm{n} / \mathrm{a}$ & $2,000 \mathrm{~km}$ truck \\
\hline $\begin{array}{l}\text { Landfill (eastern } \\
\text { Europe) }\end{array}$ & 6,400 & $\mathrm{n} / \mathrm{a}$ & $\begin{array}{l}\text { Nordic mix* } \\
\text { plus leftovers } \\
\text { from above }\end{array}$ & $\mathrm{n} / \mathrm{a}$ & $150 \mathrm{~km}$ to landfill \\
\hline
\end{tabular}

Note: * Average mix of fibres in purchased textiles in Nordic countries: Cotton 57\%; synthetics 34\%; wool 4\% other $5 \%$ (modelled as flax) (Schmidt et al., 2016).

Results of the LCA modelling

Table 9 presents a detailed overview of the results of the LCA modelling. It presents best estimates for the net global impacts of the approx. 75,000 tonnes of Nordic used textiles exported each year.

Where numbers are negative this implies a net saving rather than impact. The export of textiles from the Nordic countries gives a net positive contribution to the environment in all impact categories. The magnitude of benefits is not insignificant.

The export and subsequent reuse, recycling and treatment of used textiles gives an annual net saving of 193,000 tonnes $\mathrm{CO}^{2}$ equiv of greenhouse gases and 72 million cubic metres of water use.

It is the reuse of textiles that gives the greatest benefits in all categories. Recycling elements, give net impacts in some categories though as identified in Schmidt et al. (2016) these impacts will be lower than for alternative treatments in Nordic countries (incineration with energy recovery). The large benefits from reuse are a result of offset new textile production. 
Table 9: Global impacts of 75,000 tonnes of exported Nordic textiles

\begin{tabular}{|c|c|c|c|c|c|c|c|c|}
\hline Impact category & Unit & $\begin{array}{r}\text { Reuse } \\
\text { (cream } \\
\text { Europe) }\end{array}$ & $\begin{array}{r}\text { Reuse } \\
\text { (Grade A, } \\
\text { B and } \\
\text { tropical- } \\
\text { Africa/ } \\
\text { Middle } \\
\text { East) }\end{array}$ & $\begin{array}{r}\text { Reuse (2nd } \\
\text { grade - } \\
\text { Asia) }\end{array}$ & $\begin{array}{r}\text { Mechani- } \\
\text { cal recy- } \\
\text { cling } \\
\text { (mostly } \\
\text { Asia) }\end{array}$ & $\begin{array}{r}\text { Indus- } \\
\text { trial } \\
\text { wipes } \\
\text { (global) }\end{array}$ & $\begin{array}{l}\text { Landfill } \\
\text { (eastern } \\
\text { Europe) }\end{array}$ & SUM \\
\hline $\begin{array}{l}\text { Textiles exported } \\
\text { (excluding non- } \\
\text { textile waste) }\end{array}$ & $\begin{array}{l}\text { Tonne } \\
\text { textiles }\end{array}$ & 5,500 & 36,050 & 11,700 & 6,200 & 7,700 & 6,400 & $73,550^{*}$ \\
\hline $\begin{array}{l}\text { Acidification mid- } \\
\text { point }\end{array}$ & $\begin{array}{l}\text { k Mole of } \\
\mathrm{H}+\text { equiv }\end{array}$ & -129 & -2113 & -686 & -113 & -38 & -10 & $-3,089$ \\
\hline $\begin{array}{l}\text { Climate change } \\
\text { midpoint, excl bio- } \\
\text { genic } C\end{array}$ & $\begin{array}{l}\text { Tonne } \mathrm{CO}^{2} \text { - } \\
\text { equiv }\end{array}$ & $-16,179$ & $-139,657$ & $-45,326$ & $-7,831$ & 2,449 & 13,789 & $-192,755$ \\
\hline $\begin{array}{l}\text { Climate change } \\
\text { midpoint, incl bio- } \\
\text { genic } C\end{array}$ & $\begin{array}{l}\text { Tonne } \mathrm{CO}^{2} \text { - } \\
\text { equiv }\end{array}$ & $-13,055$ & $-102,926$ & $-33,405$ & 703 & 19,884 & 14,197 & $-114,602$ \\
\hline $\begin{array}{l}\text { Ecotoxicity freshwa- } \\
\text { ter midpoint }\end{array}$ & 1,000 CTUe & $-6,688$ & $-505,751$ & $-164,141$ & $-141,734$ & $-25,593$ & -52 & $-843,959$ \\
\hline $\begin{array}{l}\text { Eutrophication } \\
\text { freshwater midpoint }\end{array}$ & Tonne P eq & -3.0 & -8.2 & -2.7 & -1.9 & -2.0 & 0.6 & -17.2 \\
\hline $\begin{array}{l}\text { Eutrophication } \\
\text { marine midpoint }\end{array}$ & Tonne $\mathrm{N}$ eq & -53.0 & 27.6 & 9.0 & $15 \cdot 3$ & -1.0 & 0.3 & -1.8 \\
\hline $\begin{array}{l}\text { Eutrophication } \\
\text { terrestrial midpoint }\end{array}$ & $\begin{array}{l}\mathrm{k} \text { Mole of } \mathrm{N} \\
\text { eq. }\end{array}$ & -431 & $-5,007$ & $-1,625$ & -477 & -55 & -22 & $-7,617$ \\
\hline $\begin{array}{l}\text { Human toxicity } \\
\text { midpoint, cancer } \\
\text { effects }\end{array}$ & 1,000 CTUh & -0.0002 & -0.0010 & -0.0003 & 0.0000 & -0.0003 & 0.0000 & -0.0018 \\
\hline $\begin{array}{l}\text { Human toxicity } \\
\text { midpoint, non- } \\
\text { cancer effects }\end{array}$ & 1,000 CTUh & -0.0031 & -0.0400 & -0.0130 & -0.0022 & -0.0003 & -0.0001 & -0.0587 \\
\hline $\begin{array}{l}\text { lonizing radiation } \\
\text { midpoint, human } \\
\text { health }\end{array}$ & $\begin{array}{l}1,000 \mathrm{kBq} \\
\mathrm{U}_{235} \mathrm{eq}\end{array}$ & -938 & $-24,503$ & $-7,952$ & -172 & $-2,381$ & -313 & $-36,259$ \\
\hline $\begin{array}{l}\text { Ozone depletion } \\
\text { midpoint }\end{array}$ & $\begin{array}{l}\text { Tonne CFC- } \\
11 \mathrm{eq}\end{array}$ & -0.00004 & -0.00049 & -0.00016 & -0.00004 & -0.00064 & 0.0000 & -0.00137 \\
\hline $\begin{array}{l}\text { Particulate mat- } \\
\text { ter/Respiratory } \\
\text { inorganics midpoint }\end{array}$ & $\begin{array}{l}\text { Tonne } \\
\text { PM2,5-Eq }\end{array}$ & -9.7 & -235.2 & -76.3 & -4.5 & -10.9 & -0.4 & -337 \\
\hline
\end{tabular}




\begin{tabular}{|c|c|c|c|c|c|c|c|c|}
\hline Impact category & Unit & $\begin{array}{r}\text { Reuse } \\
\text { (cream } \\
\text { Europe) }\end{array}$ & $\begin{array}{r}\text { Reuse } \\
\text { (Grade A, } \\
\text { B and } \\
\text { tropical- } \\
\text { Africa/ } \\
\text { Middle } \\
\text { East) }\end{array}$ & $\begin{array}{r}\text { Reuse (2nd } \\
\text { grade - } \\
\text { Asia) }\end{array}$ & $\begin{array}{r}\text { Mechani- } \\
\text { cal recy- } \\
\text { cling } \\
\text { (mostly } \\
\text { Asia) }\end{array}$ & $\begin{array}{r}\text { Indus- } \\
\text { trial } \\
\text { wipes } \\
\text { (global) }\end{array}$ & $\begin{array}{l}\text { Landfill } \\
\text { (eastern } \\
\text { Europe) }\end{array}$ & SUM \\
\hline $\begin{array}{l}\text { Photochemical } \\
\text { ozone formation } \\
\text { midpoint, human } \\
\text { health }\end{array}$ & $\begin{array}{l}\text { Tonne } \\
\text { NMVOC }\end{array}$ & -55.0 & $-977 \cdot 5$ & $-317 \cdot 3$ & -12.4 & -23.4 & -8.7 & $-1,394 \cdot 3$ \\
\hline $\begin{array}{l}\text { Resource depletion } \\
\text { water, midpoint }\end{array}$ & $1,000 \mathrm{~m}^{3} \mathrm{eq}$ & -698.5 & $-5,962.8$ & $-1,935.2$ & $-1,602.8$ & $-61,495 \cdot 3$ & -0.7 & $-71,695 \cdot 3$ \\
\hline $\begin{array}{l}\text { Resource depletion, } \\
\text { mineral, fossils and } \\
\text { renewables, mid- } \\
\text { point }\end{array}$ & $\begin{array}{l}\text { Tonne Sb } \\
\text { eq }\end{array}$ & -0.04 & -4.11 & -1.33 & -0.06 & $-0,32$ & -0.004 & $-5,864$ \\
\hline Primary energy & & & & & & & & 0 \\
\hline $\begin{array}{l}\text { Primary energy from } \\
\text { non renewable re- } \\
\text { sources (net cal. } \\
\text { value) }\end{array}$ & GJ & $-233,634$ & $-3,201,38$ & $-1,039,011$ & $-81,697$ & $-92,123$ & $-25,832$ & $-4,673,65$ \\
\hline $\begin{array}{l}\text { Primary energy from } \\
\text { renewable resources } \\
\text { (net cal. value) }\end{array}$ & GJ & $-97,798$ & $-1,567,731$ & $-508,806$ & $-222,562$ & $-554,589$ & $-103,33$ & $-3,054,89$ \\
\hline $\begin{array}{l}\text { Primary energy from } \\
\text { renewable and non } \\
\text { renewable resources }\end{array}$ & GJ & $-331,432$ & $-4,769,19$ & $-1,547,817$ & $-304,259$ & $-646,712$ & $-129,16$ & $-7,728,55$ \\
\hline
\end{tabular}

Note: *Approximately 1,500 tonnes of the exported 75,000 tonnes comprise non-textile waste and have not been included in the impact assessment.

Table 10 demonstrates the balance between, on the one hand, savings from the avoided production of new textiles, and impacts from the collection, transport and final end-of-life of the exported textiles. Savings are significantly higher than direct impacts caused by long distance transport, and poor end-of-life waste treatment in receiving countries. 


\begin{tabular}{|c|c|c|c|}
\hline Impact category & Unit & $\begin{array}{r}\text { Benefits from avoided } \\
\text { production }\end{array}$ & $\begin{array}{l}\text { Direct impact from col- } \\
\text { lection, transport and } \\
\text { end-of-life (post reuse) }\end{array}$ \\
\hline $\begin{array}{l}\text { Climate change midpoint, excl } \\
\text { biogenic carbon }\end{array}$ & $\mathrm{kg} \mathrm{CO}^{2}$-equiv & $-251,663$ & 48,697 \\
\hline Resource depletion water, midpoint & m3 eq & $-5,970$ & 16 \\
\hline $\begin{array}{l}\text { Primary energy from renewable and non } \\
\text { renewable resources }\end{array}$ & GJ & $-4,200$ & 303 \\
\hline
\end{tabular}

It should be noted though that the impacts of the end-of-life of used textiles following reuse in developing countries have been underestimated in the LCA results. This needs to be put into context: this waste is not a direct impact associated with the export of textiles but an indirect impact (see Box 2.4). We cannot argue that the exporter has imported waste to the country. They have imported a product that eventually, at some time in the future, will become waste - just like any other product. The implications of this are discussed later.

\subsection{Socio-economic impacts and benefits in importing countries}

In this section we present a discussion of the socio-economic impacts of the export of second hand textiles from the Nordic Countries. We consider the extent to which the export of used textiles creates jobs in receiving countries and whether these are quality jobs; the extent to which the export raises money in the receiving countries via taxes, import duties etc; and whether the imports provide socio-economic benefits by providing high quality affordable clothing to those who otherwise couldn't afford it.

We also investigate potential negative aspects such as the risk that in developing countries foreign entrepreneurs benefit financially from the import of goods, which when sold, negatively affect the local textile industry with consequences for local entrepreneurs and workers.

The following effects are considered: 
- Employment-Which local organizations are involved in receiving, distributing and sales of the textiles? Does increased employment result from the trade and retail of used textiles and has their been a loss of employment in the local textile industry?

- Government revenues (taxes, import duties, etc) - including the ease of collecting revenue given local production, import of used textiles and imports of new textiles.

- Impacts on local textile production - How does the import of textiles affect and compete with the local production and distribution of textiles? Where does the key competition lie, imports of used versus imports of new or competition with local textile industry?

The assessment makes use of data and information gathered during country studies as well as existing literature. The results of the three country studies are used to make cautious conclusions on the impacts of all exports of used textiles from Nordic countries. We make clear the uncertainties involved in making such generalisations.

\subsubsection{Employment}

Previous studies indicate that significant employment is generated by the second hand textile sector in terms of handling, cleaning, repairing, re-styling, and distributing second hand clothing world wide (e.g. Oxfam, 2006).

The size of the second hand textiles sector, measured by full time employees (FTE), can be used as a metric for the employment effect arising from export of second hand textiles from the Nordic Countries. This provides a first approximation of the benefits of the inflow of used textiles to the respective countries. The employment estimates obtained in this report are rough estimates, and should be used as such. However, they give an indication of the size and relative importance of the sector.

Table 11: Estimates on full time employees arising from Nordic textiles

\begin{tabular}{l|rr} 
& $\begin{array}{r}\text { Estimated FTEs per 100 tonnes of mixed } \\
\text { imports }\end{array}$ & $\begin{array}{r}\begin{array}{r}\text { Estimated FTEs from annual } \\
\text { Nordic exports (75,000 tonnes) }\end{array} \\
\text { Sorting }\end{array}$ \\
Wholesale & 2.1 & 1,500 \\
Retail (regulated trade) & 4.0 & 2,900 \\
Total & 7.6 & 5,500 \\
\hline
\end{tabular}

Source: Cases studies in Poland, Malawi and Pakistan, ILO, UN Comtrade data. 
Table 8 presents estimates of the number of full time jobs arising from Nordic textiles. The employment per 100 tonnes of imported textiles have been drawn from interviews with importers, sorters and retailers in the country studies. These are the scaled up based on the total export of second hand textiles from Nordic countries at approximately 75,000 tonnes based on UN Comtrade data for 2014.

A number of assumptions have been taken when making these calculations:

- Textiles from the Nordic countries require the same amount of sorting as textiles imported from elsewhere. Uncertainties associated with this assumption concerns that the textiles could differ in quality and processing needs.

- All packages of textiles go through the same steps (e.g. sorting, packaging) when arriving in the recipient countries. Here uncertainties relates to some textiles going to retail, some going to wholesale and some are discarded, resulting in different processing needs.

- All companies within a country maintain identical productivity, and are thus able to process the same amount of textiles at identical speeds.

- The numbers do not include employees involved in the logistics and transport of second hand textiles.

- The numbers do not include employment in the informal sector.

Although not included in Table 8, the sale of second hand clothes imported from Nordic countries also gives rise to significant employment in the informal sector and supports a large number of families economically. A typical market seller in Malawi sells around 45 kilo (one bale) every 14 days adding up to one tonne per year. This is enough to support the seller and their family. The 1,400 tonnes of Nordic textiles that are estimated to end in Malawi each year, could thus support more than 1,000 informal market sellers.

If conditions are similar in the rest of sub-Saharan Africa, Nordic exports of used textiles that directly and indirectly reach that continent could support over 10,000 informal sellers and their families. The analysis made does not say to what extent Nordic textiles lead to net increases in employment or income in the receiving countries since jobs created in the second hand sector may to a certain extent be offset by loss of jobs in a declining domestic textile industry (see later). 


\subsubsection{Working conditions and Codes of Conducts}

It is not only the number of jobs generated in the sector that is important when assessing the effects of the exports of used textiles from Nordic countries but also the quality of those jobs. Most of the organizations and companies exporting secondhand clothing from the Nordic countries report that they require that they have standards or codes of conduct ( $\mathrm{CoC}$ ) that their purchasers must comply with (see Figure 12 under Phase 1 of the report).

These CoCs typically contains rules that set requirements and standards for the working conditions at the facilities where the second hand textiles are handled. Overall it seems that this improves the working conditions of local workers (see Appendices $($ to $E$ ). In some receiving countries, typically sorting countries in the $\mathrm{EU}$, conditions are to a certain extent secured by national regulations, which in the case of Poland are rigorously enforced by government monitoring programs (see Poland report).

Elsewhere, this may not be the case. In Pakistan, for example international watchdogs have expressed concern over workers conditions and workers rights, for example to be represented by unions (see Appendix D). In such countries CoCs are of particularly importance in guarding against excessive work hours, child labour, impingements on the right to be represented and low wages.

According to case interviews in Pakistan working conditions have improved at plants that have implemented $\mathrm{CoCs}$ demanded by Nordic exporters. Since these plants typically also import used textiles from other parts of the world, Nordic CoCs may improve the quality of a significantly larger number of jobs than those directly generated by the Nordic exports.

The improving nature of $\mathrm{CoCs}$ are enhanced if organisations work together with buyers to improve conditions in their operations, rather than simply employing a "pass or fail" filtering policy to find suitable buyers. The organisations that we followed in country studies employed this approach.

The quality of jobs in the informal sector, meanwhile, are much more difficult to determine and also more difficult to influence via CoCs. The informal sector was found to represent an important part of the second hand textiles sales in Malawi. This is thought to be typical of Sub Saharan Africa.

One potential problem with the informal sector is the use of child labour. Child labour in Malawi is relatively high, and difficult for the government to control. Furthermore, workers in Malawi are not guaranteed any standards for working conditions and safety, wage levels or social protection. The extent of these negative effects is not known, but they are probably widespread representing a challenge to the economic development of the country. 
At the same time, the informal sector provides income to large numbers of individual families who may otherwise be in poverty. The willingness by government to regulate the industry is limited as a result.

\subsubsection{Government revenues (taxes, import duties, etc.)}

Government revenues collected from the trade and retail of second hand textiles depend on several factors, including total quantities of imports and exports, the level of profit for businesses in the sector, taxes and tariffs levels, the share taken in sales by the informal (and therefore unregulated) economy and levels and collection rates of VAT.

\section{Box 2.5: Government revenues from used textiles in three study countries}

Poland, the bulk of the imported textiles are not subject to import duties, as they arrive from other EU countries. Imports of used textiles from non-EU countries are subject to a VAT of $23 \%$ and an import tax of $5.3 \%$, lower than import taxes of $12 \%$ for new textiles.

Malawi enforces a $25 \%$ import duty and a $16.5 \%$ VAT. However, since a large part of the second hand textiles are bought and sold in the informal economy no VAT or income tax revenues are generated from these transactions. The informal economy is estimated to cover $89 \%$ of the labour force, indicating that there is a lot of lost revenue in general.

Pakistan has differentiated taxes and duties depending on whether the importer is a company or an individual. The typical duties and taxes on worn clothing sum to $18.5 \%$. The Danish Embassy in Pakistan states that imported new clothing is heavily taxed, making the secondary clothes market more attractive to domestic consumers. This might also be an explanatory factor for the expanding market for second hand textiles in recent years.

Overall the trade in second hand textiles is likely to generate considerable revenues for governments in receiving countries. However due to wide differences in individual regulations, tariffs and the large informal sector in the receiving countries it has not been possible to estimate the size of these revenues.

Findings in the three study countries (see Box 2.5) illustrate that taxes and tariffs vary significantly between countries. In the Eastern European countries exemplified by Poland, tariffs are relatively low, in part because they trade mostly with other EU countries. Pakistan and Malawi having substantially higher tariffs on imports. These tariffs act partly as sources of revenues, but might also serve a political goal of protecting domestic industries. Due to the large informal economy in Malawi, it is difficult to collect revenue from sales of second hand textiles, and the same may also be true in Pakistan. 


\subsubsection{Social benefits}

One key social benefit of the export of second hand textiles is that it provides inexpensive but good quality clothing options for poorer segments of the population in final destination countries in e.g. in Asia and Africa, but also in Eastern Europe (Rogers, 2015; Norris, 2012; Hansen, 2004). The trade serves those in developing countries, who wish to move away from local, traditional clothing to more Western-looking styles (Baden and Barber, 2005). Moreover, second-hand clothing imported from Europe and elsewhere is typically cheaper than domestic production and of better quality than the other affordable option for many; cheap new clothing imports from East Asia (see Appendix B and D).

According to Brooks and Simon (2012), the average purchase prices of secondhand clothing are approximately $20-45 \%$ of new clothes in Mozambique. A recent study in Nigeria found that a majority of buyers of second hand clothing report that they are attracted to second hand textiles because of the good quality, low price and western design (Areo \& Areo, 2015).

A Malawi government official underlined that the second hand textile sector fills a gap for those not able to afford factory fresh clothes. Similarly in Pakistan, we found that cheaper second hand textiles are beneficial to the many poor in the country. Quantities of second hand textile imports have increased in recent years, in spite of the depreciation of the rupee that make these imports more expensive. This could indicate that more new, low and middle-income individuals who can't afford high costs of living are switching to used textiles (see Appendix D).

As mentioned in the employment section the informal second hand textile sector provides an important poverty-alleviation opportunity by providing a source of income for market sellers with low need for initial capital. Oxfam's research in Senegal estimated that around 24,000 people were supported economically by second hand trade, mostly in the informal sector (Barber et al., 2005) while in a single marketplace in Nairobi, Kenya, there are estimated to be 65,000 informal traders selling second hand clothing. With an estimated 100,000 tonnes of used clothing imported to Kenya each year, the total number of traders employed in the sector is estimated to lie in the hundreds of thousands (Crowe, 2014).

The trade with second hand textiles seems in particular to create job opportunities for especially women in the receiving countries. According to Areo \& Areo (2015) $70 \%$ of the employed persons in the resale of second hand textiles in Nigeria are women.

Another example of this tendency has been identified in Poland and Pakistan where women are highly valued as skilled sorters of used clothing into the hundreds of product types, sizes, styles and quality grades necessary for further sale. It is universal- 
ly accepted within the branch, whether true or not, that men can't be trained into highly skilled sorters. It takes several months to train a sorter to be able to sort into these fractions and once these investments have been made, employers are loath to let the sorters go. This means not only that sorters receive a reasonable wage, but also that they are encouraged to continue to work after marriage and childbearing as their work and skills are highly valued by the companies. This is important in countries where in other industries women receive far lower wages and conditions than men carrying out the same work.

\subsubsection{Impacts on the local textile industry}

Although the import of second clothing can give social benefits, at the same time, some have expressed concern that imports of used textiles can be and has been destructive to local textile industries.

Brooks (2015) argues that the flow of used clothing from the West - as well as the availability of cheap, new garments from East Asia - has had a negative effect on local textile industries in many countries. He particularly emphasizes impacts in Sub-Saharan Africa, where, a third of all globally donated clothes are sold. The second hand trade represents less than $0.5 \%$ of the total global trade in clothing but for many sub-Saharan African countries it is a dominant feature of the clothing market. In 2005 Baden and Barber reported that used textiles represented more than $30 \%$ of the total value of imports, and more than $50 \%$ in volume terms.

The data in Figure 19 suggests that used textiles have become more dominant in recent years. Exceptions are Nigeria, Zimbabwe and South Africa, countries with tight restrictions on used textile imports. At least according to official figures, used textiles play a minimal part of textile imports in these countries. However, according to Abimbola (2012) large quantities of textiles are smuggled into Nigeria via neighbouring Benin.

Brooks points to Ghana and Nigeria as countries where local industries have been particularly negatively affected. Ghana's textile and clothing employment fell by $80 \%$ between 1975 and 2000 while Nigeria's 200,000-person textile workforce has gradually disappeared.

This picture can be seen across much of Sub-Saharan Africa and also elsewhere. $85 \%$ of Kenya's textile plants have closed since the early 1990s, while cotton output is a tenth of 1990 s levels (Crowe, 2014). According to Brooks the trade dynamics and systems deny the world's poorest "ways to climb out of poverty". One should note that Brooks does not claim second hand clothing to be worse than new clothing in this respect. 
Imports of used textiles on the domestic industry are most likely where the industry has been principally focused on serving the domestic market. Used textiles may certainly be serving a significant part of domestic needs. In Kenya, Rwanda, Uganda, Tanzania and Malawi, imports of used textiles had grown to nearly or just over $2 \mathrm{~kg}$ per person in the population per year by 2014 (see Figure 20). Ghana showing double this but much of Ghana's imports are for re-distribution elsewhere in the continent. 2 $\mathrm{kg}$ represents a good share of minimum clothing needs.

Figure 19: Imports by value of new and used textiles to selected sub-Saharan countries with declining local industries, 2000-2014

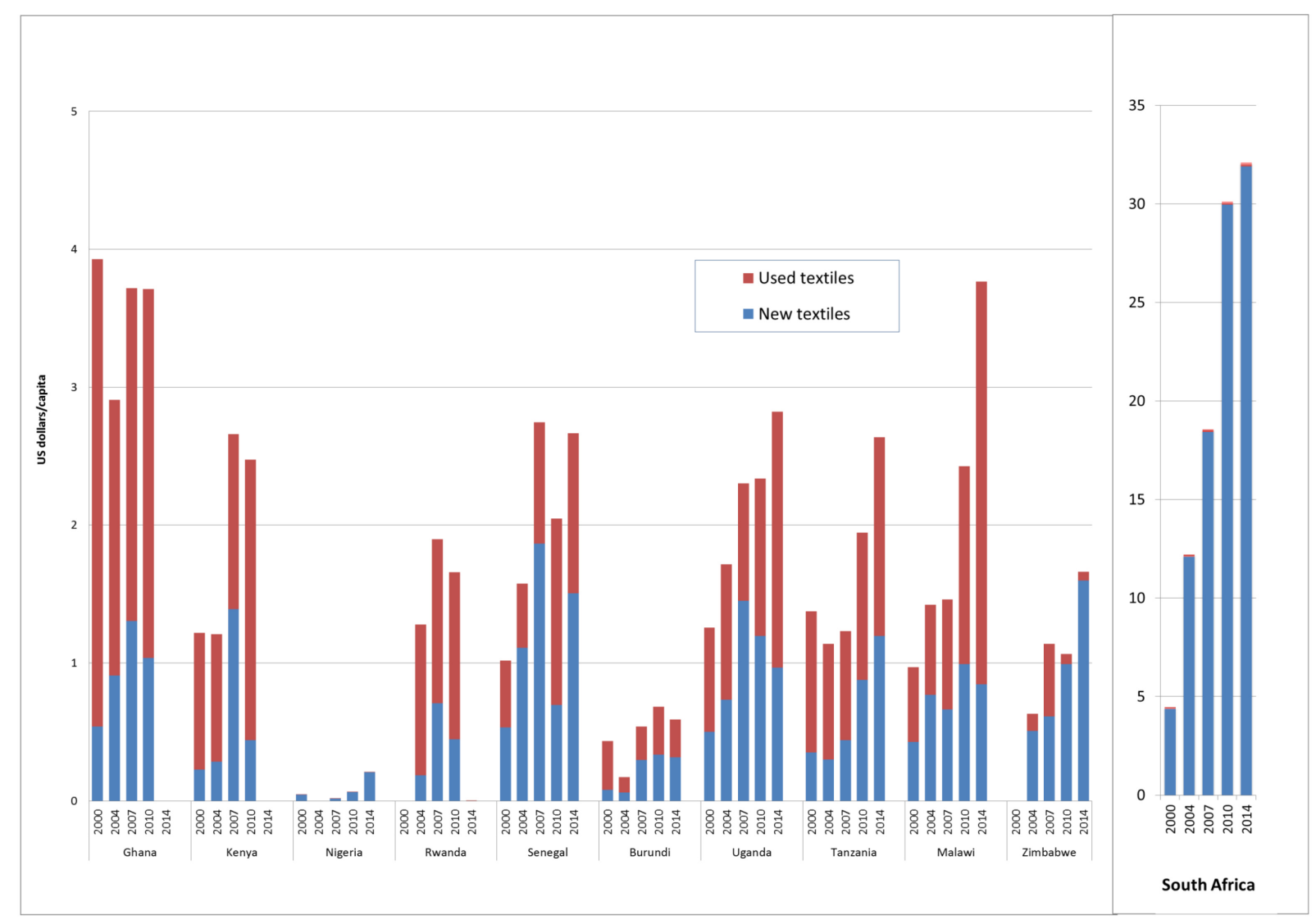


Figure 20: Imports by weight of used textiles to selected sub-Saharan countries with declining local industries, 2000-2014

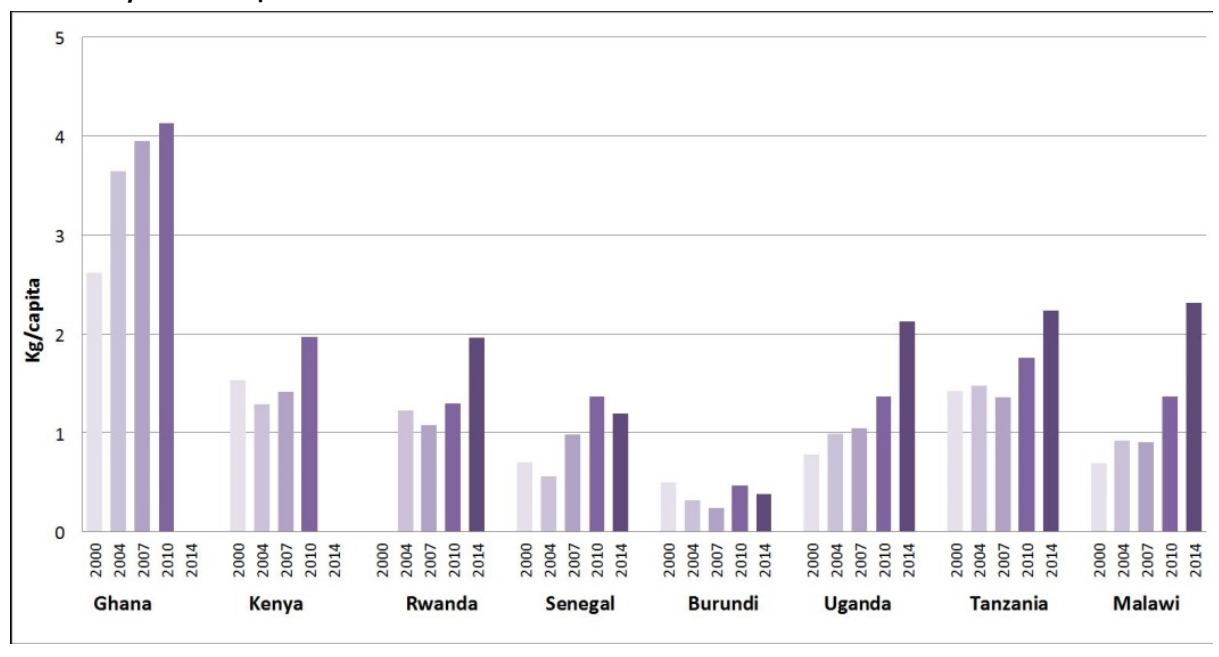

A key question is whether, if the second hand trade had been removed, the domestic industry would have been under less threat, or whether the gap would just have been filled up by further imports of cheap new textiles from Asia. African industries may simply not be competitive against either imports of second hand or of new textiles. Imports of both have been growing rapidly (see Figure 19) due in part to the erosion of trade barriers over the past two decades.

\section{Box 2.6: The domestic textile industry in three study countries}

Malawi: employment in the local textile industry declined from 10,500 employees in 1998, to 3,300 by 2011, representing about $10 \%$ of manufacturing

According to government officials and industry representatives, the reasons for the decline are a combination of low skills, changes in trade agreements, high inflation rates and imports of cheap Chinese textiles. The domestic industry is not competitive in either the domestic market or for export. While there might be a negative effect on the employment in the domestic textile production it might be outweighed by the benefits of the second hand textile sector in poverty reduction and employment in the informal sector.

Pakistan has a large textile industry, accounting for approximately $10 \%$ of GDP and employing $40 \%$ of the industrial labour force

The domestic textile industry exports $70 \%$ of its production and is thus largely influenced by international economic conditions rather than domestic circumstances. Imports of second hand textiles are unlikely to have an impact on the export-orientated industry as a whole. Indeed the clothing industry 
in Pakistan has grown consistently despite increases in the imports of second hand textiles. SMEs that aim to supply local demand are more likely to be affected. Sources indicate that as much as $50 \%$ of domestic demand for clothing is satisfied by imported clothing, some of which is second hand.

Poland, has 17,000 firms in the textile and clothing industries employ some 150,000 people Earlier the industry focused on manufacturing clothing for western European brands but is transforming itself into a fashion industry with an increasing number of Polish brands selling clothing on the domestic but also the export market. During the late 1990 s and early 2000 s there was significant poverty and some segments could only afford either cheap low quality imports from Asia or second hand from western Europe. These were both priced considerably lower than domestically produced garments. Both government officials and the textile branch itself agree that the main threat to the local industry was from cheap Asian imports. More recently, as income increased the growing middle class has shifted demand towards higher quality domestically produced textiles. The second hand sector has not been considered as a threat by the textile industry for nearly a decade.

According to Barber et al. (2004) imports of second hand textiles put pressure on the local production of textiles in Senegal following market liberalisation in the country in the mid-1980s. This sector is, however, also likely to have been affected by new imports and internal constraints. Barber et al. conclude that in more recent years imports of second hand have only a limited impact on the local industry. One reason for this is that the local production is limited to a specific market segment that does not compete with second hand imports. The report also highlights that the major cause of decline in local production is the increasingly cheap import of new clothing from Asia, combined with lack of efficiency in the local industry due to supply-side constraints, lack of investment, high cost of inputs and lack of access to credit.

According to Crowe (2014) the decline of the local industry is a result of economic changes that have swept the continent. Until the 1980s, high tariffs protected domestic textile industries and other businesses. Then economic liberalization programs, backed by the World Bank and the IMF, started taking hold in Africa. Tariffs were lowered, cheap imports flooded in and local factories had to contend with new competition. Many failed and closed down.

This literature is partially backed up by our findings in Malawi (see Box 2.6). Here government officials and industry representatives did not see used textile imports as the chief underlying cause of the decline in the domestic industry but rather a lack of competitiveness in the local industry. The second hand sector is also thought to have had an impact but this is felt by government officials to be offset by positive effects arising from increased income and opportunities arising from the imported textiles in the second hand sector. 
Looking beyond Africa, in Poland and Pakistan, used textile imports do not currently seem to be threatening the local textile industries. In Pakistan the rapidly growing industry is focused on the export market and therefore relatively unaffected by increasing imports of second hand for the domestic market (see Box 2.5). Some SMEs with a focus on this market may be suffering. In Poland, the demand for second hand has declined as incomes have increased and the textile industry is bolstering itself against threats of cheap new textiles from Asia by specialising in technical textiles.

\subsubsection{The effect of import bans}

As described above, the textile industry across sub-Saharan Africa has been negatively affected over the past decades by growing imports of cheap new textiles from Asia and perhaps, though to a lesser extent, by imports of used textiles primarily from the west. Successive trade agreements under GATT and WTO, particularly the 10-year transitional programme of the WTO's Agreement on Textiles and Clothing (ATC) initiated in 1995, have forced governments to remove protection from the local textile industries. These have found it difficult to compete in price and technology with production in Asia both on the domestic and export markets.

These agreements limit the degree to which governments in Africa can use import tariffs or other means to restrict the import of new textiles. However, some governments have chosen to impose restrictions on used textiles, to which the free trade agreements don't apply, as the only means available to them for protecting local industries. Such restrictions have been mapped out in detail under section 1.3 in Phase 1.

Governments in the East African Community, a trade bloc comprising Kenya, Tanzania, Uganda, Rwanda and Burundi, are planning to impose a ban on imports of second-hand clothes by 2019, in an attempt to protect the local industry (The Economist, 2016). Certainly the trade of second hand clothing has significant dimensions in these countries. Kenya imports 100,000 tonnes a year. At the same time the country is building up a new garment-making business with a focus on exports. Kenyan factories exported garments worth USD 335 million in 2013 and the business employed 40,000 people (Crowe, 2014).

It isn't clear why the Kenyan government feels that the import of used textiles represents a threat to an export-orientated business. The reason might be to encourage a shift of workers from the second-hand sector to a growing textile industry (The Economist, 2016). Certainly a ban would risk tens of thousands of informal jobs in the second hand sector and as a result many feel that the ban will never be adopted (ibid). 
Promoters of a ban, point to South Africa as an example, a country that has had a long-term ban on imports of used textiles intended for reuse and a surviving textile industry.

However, the industry in South Africa has also been in decline despite the ban. Employment dropped from 200,000 to 110,000 in $2014 .{ }^{12}$ Trade liberation and the fact that the industry has been unable to compete with the influx of cheaper clothing from Asia is the main explanation of the decline in the industry ${ }^{13}$. The import of new cheap clothes from China has increased significantly since $2004^{14}$. The value of imported new textiles have increased by more than a factor 6 since 2000) and is an order of magnitude higher per capita than other parts of the continent (see Figure 19).

The growth has been a direct result of removal of trade barriers following entry into to WTO in 1994. The industry has not been able to compete with Asian manufacturers due to old equipment and lack of experience in international trade (see Appendix B).

It, therefore, seems that the ban on second-hand has not protected the domestic textile industry. Government officials and industry representatives interviewed largely concur with this. The ban is also difficult to enforce due to smuggling of used textiles from neighbouring countries with no such ban or restrictions.

Despite sharp penalties for smugglers defying the ban, interviewees in Malawi spoke of being regularly approached by businesses in South Africa and Zimbabwe (another country with an effective ban) with offers to purchase Malawi imports (Appendix B). Similarly, considerable quantities of second-hand clothing are smuggled into Nigeria (a country with a strict ban) from neighbouring Benin (Abimbola, 2012).

According to The Economist (2016) a ban could backfire for the Kenyan government if it encouraged an increase in smuggling across borders. The result may not be a reduction in the amount of second hand being sold in markets but the state would lose the $35 \%$ tariff it currently applies to imports of used textiles.

Despite these risks and a lack of evidence of any positive effect on the textile industry, the South African government reports continuing with the ban. Interviewees did not express protection of the industry as the reason but rather hinted that it was a case of national and cultural pride in the wake of apartheid; a principle against the country being a dumping ground for discards from former colonial powers (see Appendix B).

\footnotetext{
${ }^{12}$ Statistical realise $\mathrm{P}_{3002}$, Manufactuirng Industry 2014, Statistics of South Africa.

${ }^{13}$ Feature: A turnaround for South Africa's textile industry?

${ }^{14}$ Textile and clothing industry in South Africa, Etienne Vlok, 2006.
} 


\subsection{Discussions and recommendations}

The three country studies have given us some indications of the potential socioeconomic and environmental benefits and impacts of the 75,000 tonnes of textiles exported from Nordic countries in receiving countries.

\subsubsection{A dynamic market}

The market for used textiles is largely driven by economic inequality between and within countries. The top $10 \%$ quality of discarded textiles in the Nordic countries can be sold for reuse domestically but the remainder must find markets elsewhere where populations have lower incomes and are less able to afford new. In addition, the labour intensive work of sorting textiles into fractions for reuse and recycling has also moved from the Nordic countries out to Eastern Europe where wages are lower.

The market is dynamic. End destinations for Nordic exports are under constant development as economic conditions in destination countries change. Lower grade used textiles that ten years ago could have been sold for reuse in Poland for example, are no longer in demand as people's income has increased and they are able to afford better quality second hand and new. New markets have been found further afield in Eastern Europe, the Middle East or Asia. Thus the reuse and recycling of textiles can be described as a cascade in quality and value that spreads from rich countries out to poorer ones.

In recent years the market has been characterised by a glut of discarded textiles collected in US, Europe and elsewhere, chasing a somewhat dwindling demand as economic growth increases incomes abroad. This has led to reduced prices for unsorted original and sorted fractions on global markets.

\subsubsection{Tight margins lead to efficient use}

Rather than reducing the share of exported Nordic textiles which are reused and recycled, reduced prices have actually led to their increase. The reason is that buyers of original (unsorted textiles) are forced to find a market for every single fraction that they contain in order to be able to pay for labour costs, costs of machinery and so on.

No longer can they make ends meet just selling the approximately $10 \%$ cream and the $45 \%$ grade $A$ and $B$ and African mix. They also have to sell 2 nd grade textiles, rags for mechanical recycling, plastic bags for plastic recycling despite the very low price for these fractions. 
The result is that the full value of the exported used Nordic textiles is utilised as far as possible. Reusing yields a higher price than recycling, and recycling yields higher prices than other waste treatments. Schmidt et al. (2016) found that reuse also gives significant environmental benefits than recycling, and that recycling gives greater environmental benefits than incineration with energy recovery in Nordic countries.

Therefore, economics is a positive driver to ensuring that the waste hierarchy is met and the tight margins ensure that most environmental gain is raised from exported Nordic textiles.

\subsubsection{Significant global environmental benefits}

The export is estimated to lead to give substantial environmental benefits since the impacts caused by the transportation and processing of used textiles are small in comparison to the savings caused by offset new textile production.

The exports are estimated to give an annual net saving of 193,000 tonnes $\mathrm{CO}^{2}$ equiv of greenhouse gases and 72 million cubic metres of water use, and a host of other environmental benefits.

It would be more correct to compare these benefits to the environmental benefits that could be gained from the same textiles if they hadn't been exported. Under current conditions this would mean that the majority would be incinerated with energy recovery since domestic markets don't exist to reuse or recycle 75,000 tonnes of additional used textiles. This would give far lower environmental benefits than the current fate of the textiles.

This is not to say, however, that Nordic markets couldn't be developed for these textiles given political will to create the right economic signals to encourage changes in consumption patterns, and technology advances to allow efficient domestic sorting and recycling. Under current conditions, however, the export and pathways of Nordic used textiles seems to optimise environmental benefits.

\subsubsection{Local environmental impacts}

One key environmental concern related to exports of textiles - that it leads to the export of waste to countries that are less able to deal with it - was also found to be largely unfounded, since:

- All non-reusable/non-recyclable textile and non-textile waste is removed at sorting facilities in EU Member States in eastern Europe prior to export to the rest of the world. 
- All or nearly all waste treatment facilities in EU Member States in eastern Europe comply with EU minimum standards.

- Due to narrow margins all textiles exported to developing countries are reused or recycled.

In other words, the vast majority of fractions sent to developing countries seem to be made use of either via reuse or recycling.

One remaining potential concern, which can be characterised as an indirect effect, is what happens to the Nordic textiles after they have been reused in developing countries and have become too worn out to be used any more. Certainly in Malawi and Pakistan a large share of household waste remains uncollected and/or ends in unregulated dumps or burnt on open fires. It could be argued that this is no more the responsibility of exporters of used textiles than it is the responsibility of exporters of any other non-hazardous products to developing countries, to ensure that these are treated correctly end-of-life.

In a period of increasing extended producer responsibility, however, one can begin to argue for the acceptance of such responsibility by exporters. The application of this responsibility is difficult but could perhaps include supporting the establishment of textile waste collection points in receiving countries. The Recycle Sub-Sahara project in Tanzania and the MiMA-TE up-cycling business concept in Mozambique are examples of how this can be implemented. ${ }^{15} 16$

\subsubsection{Job creation and codes of conduct}

The export of Nordic used textiles is estimated to lead to significant job creation along its value chain. Our rough estimate is the support of approximately 1,500 full time equivalent jobs in sorting, 2,000 in wholesale and 5,000 in the regulated retail sector. The numbers of families supported in the informal sector in developing countries through sales of used textiles in market places could be even higher. The approximately 12,000 tonnes of Nordic textiles exported to the African continent alone are estimated to support more than 12,000 market sellers and their families. However, if the trade in used textiles offsets the trade and manufacture of new textiles in the receiving countries, net employment generated by Nordic exports may be lower than this.

\footnotetext{
${ }^{15} \mathrm{http} / / /$ nominateforindexaward.dk/Presentation/read/id=MjEzOO

${ }^{16}$ http://amandaericsson.com/research/mima-te-mozambique/
} 
The same tight economic margins that ensure that all fractions of used textiles are put to good use, can also drive owners of sorting facilities to pay low wages and cut corners in health and safety. In countries such as Poland with well-enforced minimum wages and working conditions this is guarded against by the state. Elsewhere, exporters have a strong responsibility for ensuring decent working conditions in sorting facilities and further down the value chain.

As described under section 1.4, Codes of Conduct have a strong potential here, although only if regularly monitored and enforced. Moreover, they are more effective at influencing conditions downstream, when applied to sorters with their own retail shops, than wholesalers who sell on the global market to large numbers of retailers.

In general Codes of Conduct can have little influence on working conditions in the informal sector, due to limited ability to monitor conditions. Typical market sellers in the informal sector seem to be self-employed individuals or family businesses and not employers of others. However, there is a high risk of child labour in this sector. Careful thought is needed in how this can be guarded against in a workable Code of Conduct or via other means.

Although, economics currently ensure that reuse and recycling are prioritised, should a situation arise again in the future where demand exceeds supply Codes of Conduct will become important tools in ensuring that the waste hierarchy is adhered to.

\subsubsection{Impacts on domestic textile industry}

Used textiles from Europe and other rich regions appear to represent an important source of clothing for a significant part of populations in sub-Saharan Africa. More than half, by value, of imported textiles to Kenya, Ghana, Rwanda, Uganda, Tanzania and Malawi are used and the share measured by weight is probably much higher. Used textile imports to these countries represent around $2 \mathrm{~kg}$ per capita if averaged over the entire population, a good share of the minimum clothing needs of an adult.

Used imports provide cheap and good quality clothing for those who otherwise may not be able to afford it. On the other hand, these imports may also have contributed to the decline of the domestic textile industry in these and other sub-Saharan countries.

What is not clear is whether the decline of the domestic industry would have happened anyway, even in the absence of the second hand sector. There is certainly evidence that domestic industries have been unable to compete with production in Asia as trade barriers were removed during the late 1990 s and early 2000 s due to older, less efficient production equipment and processes. This has affected both domestic and export markets. Both used and new textile imports have increased rapidly since at 
least 2000 across sub-Saharan Africa. There is no evidence that in the absence of used textile the gap would not simply have been filled by additional imports of cheap new textiles from Asia.

Bans on second-hand seem rather to be a sticking plaster than a real solution. Certainly the ban in South Africa has not stemmed the decline in the domestic industry. Moreover, imports of new clothes to South Africa per capita are ten times higher in value than total imports of new and used to the other mentioned countries. Bans can also risk negative side effects. Trade can shift to illegal pathways via smuggling from countries without restrictions, and an associated loss of revenue in the form of import duties. Perhaps more importantly, they would damage what many governments have appreciated as being an important poverty-reducing activity. It is relatively easy to start-up as a market trader in second hand clothing with little need for capital, and the second hand sector in sub-Saharan Africa and elsewhere has pulled tens of thousands of families out of poverty.

There may be better ways to reduce the impact of second hand on the domestic textile industry; for example by focussing on production for the export market, by specialising in particular kinds of textiles where a gap can be identified, and by investing in modern equipment and processes to allow the industry to compete on global markets. All this will require significant investments that, in developing countries, may need to be attracted from elsewhere.

Considering all of the above, we make the following recommendations.

\subsubsection{Recommendations for Nordic collectors/exporters of used textiles:}

- Adapt or adopt a Code of Conduct for your own operations and for downstream operators with emphasis on:

- Working conditions, wages and H\&S.

- Goals for reuse and recycling shares and treatment options for remaining waste.

- Effective and regular monitoring, reporting and follow-up.

- Assist as far as possible your existing buyers to meet your requirements rather than switching buyers as soon as there is non-compliance.

- Where possible prioritise buyers with their own retail shops rather than wholesalers to improve or simplify traceability.

- Where possible nurture long-term relationships with buyers to ensure that exports are matched to needs and waste is avoided. 
- Remove obvious textile and non-textile waste from original prior to export.

- Prioritise exports of original to EU and EEA countries for sorting.

- Investigate opportunities to support better collection and treatment of postconsumer worn out textiles in receiving countries.

- Engage in projects with the aim of increasing reuse and recycling within Nordic markets.

\subsubsection{Recommendations for Nordic policy-makers}

- Develop guidelines for collectors and exporters on interpretation of national, European and international regulations on the transport of used textiles.

- Assist in the further development of, and encourage the adoption by collectors of the Nordic Council of Ministers pilot Code of Conduct.

- Assist developing countries in collection and treatment of household waste (since the lack of waste management is broader than simply textiles).

- Establish strategies, seeding project, innovation funding pools etc. for encouraging stronger markets for reuse and recycling of textiles in Nordic markets.

- Continue and increase support for increased collection of used textiles both for the Nordic and export markets. 


\section{References}

Abimbola, O (2012) The International Trade in Secondhand Clothing: Managing Information Asymmetry between West African and British Traders. Textile: The Journal of Cloth and Culture, 10:2, 184-199.

Areo and Areo (2015): Morphology, Marketing and Consumer Attitudinal Evaluation of Second Hand Clothing; Academic Research International Vol. 6(4) July 2015.

Baden, S. and Barber, C. (2015) The impact of the second-hand clothing trade on developing countries. Report published by Oxfam, Oxford, UK.

Barber C, Gowthaman, B., Rose, J. (2004) Stitched Up - How rich-country protectionism in textiles and clothing trade prevents poverty alleviation, Oxfam Briefing Paper. http://policypractice.oxfam.org.uk/publications/stitched-up-how-rich-country-protectionism-in-textilesand-clothing-trade-preve-114604

Brooks, A. (2015) Clothing Poverty: The Hidden World of Fast Fashion and Second-hand Clothes. London: Zed Books.

Brooks and Simon (2015) Unravelling the Relationships between Used-Clothing Imports and the Decline of African Clothing Industries; Development and Change 43(6) 1256-1290;2012.

Crowe, P. (2014) Nairobi's Gikomba Market Is Like Fifth Avenue, Except Everything's Secondhand. Article published by Reuters Oct 15 2014. http://www. businessinsider.com/r-theglobal-business-of-secondhand-clothes-thrives-in-kenya-2014-10? $r=U S \& \mid R=T \& I R=T$

EEA, (2013), Environmental pressures from European consumption and production. EEA Technical report No 2/2013. http://www.eea.europa.eu/publications/ environmental-pressuresfrom-european-consumption

Elander, M., Gíslason, S., Hanssen, O. J., Kiørboe, N., Palm, D., Watson, D., Rubach, S. (2015) The Nordic textile commitment: A proposal of a common quality requirement system for textile collection, sorting, reuse and recycling. Temanord Report for the Nordic Council of Ministers

Elander, M., Sörme, L., Dunsö, O., Stare, M., Allerup, J., (2014) Konsumtion och återanvändning av textilier. SMED rapport $\mathrm{Nr} 1492014$.

Hansen, K. T. (2004) Helping or hindering? Controversies around the international second-hand clothing trade. Anthropology Today, 20, 4, 3-9.

JRC (2014) Environmental Improvement Potential of textiles (IMPRO Textiles) Joint Research Centre Scientific and Policy Reports. European Commission.

$\mathrm{KICl}$ (2013) Personal communication with André Jansen, CEO of $\mathrm{KICl}$ (David Palm) during the Swedish Red Cross Kupan-conference spring 2013.

Morley, N.J., Bartlett, C., McGill I. (2009). Maximising Reuse and Recycling of UK Clothing and Textiles: A report to the Department for Environment, Food and Rural Affairs. Oakdene Hollins Ltd.

Norris (2012) Trade and Transformations of Second hand Clothing: Introduction; TEXTILE, 10:2, 128-143. 
Palm, D., M. Ellander, D. Watson, N. Kiørboe, H. Salmenperä, H. Dahlbo, K. Moliis, K.A. Lyng C. Valente, S. Gíslason, H. Tekie, S. Harris, T. Rydberg (2014) Towards a Nordic textile strategy: collection, sorting, reuse and recycling of textiles. Temanord Report for the Nordic Council of Ministers.

Pietra, R. (2014) The Travels of a T-Shirt in the Global Economy: An Economist Examines the Markets, Power, and Politics of World Trade. Wiley. Kindle Edition.

Politiken (2015) Afrika takker nej til dit brugte tøj. Article printed in Dabnish newspaper $16^{\text {th }} \mathrm{July}$ 2015. http://politiken.dk/forbrugogliv/forbrug/ECE2759415/afrika-takker-nej-til-dit-brugtetoej/

Rogers, L. (2015) Where do your old clothes go? Article published in BBC News Magazine, $11^{\text {th }}$ February 2015. http://www.bbc.com/news/magazine-30227025

Schmidt, A., Watson, D., Roos, S., Askham, C. \& Brunn Poulsen, P. (in press) Life Cycle Assessment (LCA) of different forms of reuse, recycling and incineration of textile waste: Phase 2 Report. Report for Nordic Council of Ministers Waste Group.

Swiss Federal Office for the Environment, (2016) Exporting consumer goods: Second-hand articles or waste?: Useful tips for dealers, carriers and relief organisations. 2nd updated edition http://www.bafu.admin.ch/publikationen/publikation/01613/index.html?lang=en

The Economist (2016) Let Them Weave Their Own: the government takes aim at well-meaning foreigners. On-line article 2nd April 2016. http://www.economist.com/news/middle-east-andafrica/21695877-government-takes-aim-well-meaning-foreigners-let-them-weave-their-own

Tojo, N., Kogg, B., Kiørboe, N., Kjær, B. and Aalto, K. (2012): Prevention of textile waste - material flows of textiles in three Nordic countries and suggestions on policy instruments TemaNord 2012:545, Nordic Council of Ministers.

Tukker, A., Huppes, G., Guinée, J., Heijungs, R., de Koning, A., van Oers, L., Suh, S., Geerken, T.,van Holderbeke, M., Jansen, B. \& Nielsen, P. (2006) Environmental impacts of products (EIPRO) Analysis of the life cycle environmental impacts related to the total final consumption of the EU $\square$ 25, Sevilla: Institute for Prospective Technological Studies, EUR 22284 EN.

Watson, D., Kiørboe, N., Kjær, B., Lindblad, B., Dammand, K., Nielsen, R. (2014a) Mindre affald og mere genanvendelse i tekstilbranchen: Idéer fra aktørerne på tekstilområdet. Danish EPA, Report series Undgå affald, stop spild nr. 03, 2014.

Watson, D., Schmidt, A., Roos, S., Askham, C. \& Brunn Poulsen, P. (unpublished) Life Cycle Assessment (LCA) of different forms of reuse, recycling and incineration of textile waste: Phase 1 Report - definition of scope and methodology. Internal report for Nordic Council of Ministers Waste Group. Delivered 8. May 2015. 


\title{
Sammenfatning
}

\author{
Baggrund og formål
}

Reduktion af tekstilers miljøpåvirkninger er et centralt tema for Nordisk Ministerråd under Grøn Vækst programmet. Et af fokusområdet har været at stimulere indsamling, genbrug og genanvendelse af brugte tekstiler.

Indsamlingsprocenter for brugte tekstiler varierer fra $22 \%$ i Sverige til $46 \%$ i Danmark, hvoraf størstedelen af resterne ender i blandede affaldsstrømme til forbrænding. Indsamling af brugte tekstiler udføres primært af velgørenhedsorganisationer med det formål at generere et overskud til finansiering af velgørende aktiviteter. En stor andel af de indsamlede tekstiler bliver solgt på det globale marked.

Der findes kun begrænset viden om mængder, endelige destinationslande, og hvad der sker med tekstilerne ved ankomst. Der er også mangel på oplysninger om, hvorvidt de samlede sociale, økonomiske og miljømæssige påvirkninger af denne eksport er positive eller negative.

Formålet med dette projekt har været at kortlægge eksport af brugte tekstiler fra nordiske lande og estimere de potentielle sociale, økonomiske og miljømæssige konsekvenser, fordele og risici for disse tekstiler i modtagerlandene.

\section{Kortlægning af eksporterede tekstiler}

Eksporten af brugte tekstiler fra fire nordiske lande (Danmark, Finland, Norge og Sverige) blev kortlagt med brug af statistikdatabaser, der giver oplysninger om de først e destinationer, og gennem interviews med de 13 største nordiske eksportører, som bidrager med information om tekstilernes videre veje.

Ifølge den statistiske data er eksporten af nordiske brugte tekstiler øget med 60.000 tons i 2011 til 75.000 tons i 2014. Tekstilerne bliver eksporteret direkte til flere end 100 lande, men $82 \%$ af eksporten går til kun 10, hvoraf ni ligger inden for EU.

Interviews med indsamlere gav et indblik $\mathrm{i}$, hvad der sker med tekstiler efter deres ankomst til første destination. Tilsammen rapporterede de 13 interviewede at have eksporteret lidt over 70.000 tons tekstiler fra de nordiske lande i 2014. Hovedparten sælges til grossister, store sorteringsfirmaer eller second-hand sælgere for at skaffe penge til 
velgørende aktiviteter. Donation af tekstiler som direkte bistand eller nødhjælp er meget begrænset. Indsamlere forlanger i stigende grad at købere opfylder krav angående arbejdsvilkår for ansatte. Færre stiller krav eller modtager regelmæssige rapporter om fordeling af de købte tekstiler til genbrug, genanvendelse og øvrig affaldsbehandling.

En fjerdedel af de tekstiler, som eksporteres af de 13 indsamlere, er blevet præsorteret i de nordiske lande for at skimme de $10 \%$ bedste kvalitet til salg i nordiske lande og for at fjerne affald. De præsorterede tekstiler er primært eksporteret inden for Europa men også længere væk.

De resterende tre fjerdedele af de eksporterede tekstiler er usorteret ("original") bortset fra overfladisk fjernelse af ikke-tekstil affald. "Original" er næsten udelukkende eksporteret inden for EU-grænser til sortering, primært i Østeuropa.

Efter sortering af tekstilerne sælges fraktionerne på hjemmemarkedet eller sælges på det globale marked. Østeuropa er en vigtig slutdestination for nordiske tekstiler, men ikke-europæiske lande er også vigtige. Mindst 7.500 tons, eller $11 \%$ af alle eksporterede nordiske tekstiler, ender i Indien eller Pakistan, mens 12.000 tons (18\%) ender på det afrikanske kontinent.

I de tilfælde, hvor affald (enten tekstil eller ikke-tekstil) forekommer i de brugte tekstiler eksporteret fra de nordiske lande, forbliver dette enten i Europa i de sorterende lande, hvor det behandles forsvarligt, eller eksporteres til Østasien - primært Indien og Pakistan - for mekanisk genanvendelse. Der forekommer kun meget lidt tekstilaffald i eksporten til de afrikanske lande.

\section{Et dynamisk marked}

Der blev foretaget dybdegående undersøgelser i tre udvalgte lande - Polen, Malawi og Pakistan - for at undersøge, hvad der sker i forskellige dele af værdikæden, og give et billede af de globale effekter af handlen.

Genbrug og genanvendelse af tekstiler kan beskrives som en kaskade, hvad angår kvalitet og værdi, som spreder sig fra de rige lande ud til de mere fattige. De $10 \%$ tekstiler af højeste kvalitet ("creme") kan sælges til genbrug på hjemmemarkedet i de nordiske lande. Den resterende del må finde markeder, hvor befolkningen er mindre velhavende. De bedre kvaliteter forbliver i Europa, primært i den østlige del inklusiv Rusland. Såkaldt "Tropical mix" og tekstiler af lavere kvalitet eksporteres til Afrika, Mellemøsten og Centralasien.

De endelige destinationer er under konstant udvikling i takt med økonomisk vækst. Tekstiler af lavere kvalitet, som for ti år siden kunne sælges til genbrug i Polen, 
efterspørges ikke længere. Nye markeder flyttes længere væk til Østeuropa, Mellemøsten eller Asien.

I de seneste år har markedet været præget af en overflod af brugte tekstiler indsamlet i USA, Europa og andre steder, som søger en svindende efterspørgsel i takt med at økonomisk vækst øger indkomsten i udlandet. Dette har ført til lavere priser for brugte tekstiler på det globale marked.

\section{Marginalt overskud fører til effektiv udnyttelse}

Lavere priser øger andelen af brugte tekstiler, som genbruges og genanvendes. Købere af "original" tvinges til at finde et marked for hver enkel fraktion, som tekstilet indeholder, for at være i stand til at betale for sorteringsomkostninger.

Sorteringsfirmaer kan ikke længere få det til at løbe rundt ved udelukkende at sælge de genbrugte tekstiler af bedre kvalitet. De skal også sælge de lavere kvaliteter til genbrug, klude til mekanisk genanvendelse og plastikposer til plastikgenbrug, på trods af den meget lave pris på disse fraktioner. Den fulde værdi af de eksporterede brugte nordiske tekstiler udnyttes således i videst muligt omfang.

Eftersom genbrug giver en højere pris end genanvendelse, og genanvendelse giver højere priser end anden affaldshåndtering, sikrer de stramme økonomiske vilkår også, at affaldshierarkiet bliver opfyldt så vidt muligt. Det sikrer, at der opnås flest mulige miljøgevinster fra eksporterede nordiske tekstiler.

\section{Væsentlige globale miljømæssige fordele}

En årlig nordisk eksport af 75.000 tons brugte tekstiler skønnes at give en årlig nettobesparelse på 193.000 tons $\mathrm{CO}^{2}$ ækvivalenter af drivhusgasser og 72 millioner kubikmeter vand og et væld af andre miljømæssige fordele.

Fordelene skyldes, at effekterne af transport og behandling af brugte tekstiler er lave i forhold til de besparelser, som er forsaget af, at man undgår ny tekstilproduktion. Dette til trods for konservative estimater for, i hvilken grad salg af brugte tekstiler opvejer produktionen af nye tekstiler.

Fordelene er langt større, end hvad det ville være muligt at opnå, hvis tekstilerne forblev i de nordiske lande under nuværende vilkår. I dette tilfælde ville størstedelen af indsamlede tekstiler blive forbrændt med energiudnyttelse; der findes lige nu ikke hjemmemarkeder for genbrug eller genanvendelse af 75.000 tons ekstra brugte tekstiler. 


\section{Lokale miljøpåvirkninger}

Bekymringen omkring, at eksportmarkedet fører til eksport af affald til lande, der i mindre grad er i stand til at håndtere det, var ikke begrundet. Næsten alt ikkegenanvendeligt tekstilaffald og alt ikke-tekstilaffald fjernes ved sorteringsanlæg i EUmedlemslande i Østeuropa forud for eksport til resten af verden. Siden hovedparten af affaldshåndteringsanlæggene i Østeuropa nu opfylder EU-minimumstandarder, behandles affaldet forsvarligt. Især når stramme økonomiske vilkår tilskynder, at sorteringsfirmaer sælger så mange fraktioner som muligt til genanvendelse.

De stramme økonomiske vilkår betyder også, at næsten al tekstileksport til udviklingslande er genbrugt eller genanvendt. Vi var dog ikke i stand til indhente oplysninger om miljøprofilen på genanvendelsesanlæg i Asien.

Importerede nordiske tekstiler til genbrugsmarkeder kan indirekte føre til lokale miljøpåvirkninger i Afrika og Asien, når de lokale forbrugere har slidt tøjet op. Dette skyldes en begrænset indsamling af husholdningsaffald særligt i landområderne, og en ikke optimal håndtering af det indsamlede affald. Dette gælder også for import af nye tekstiler. Der findes ikke meget information om, hvad der sker med tøj i udviklingslande, når det ikke længere kan repareres.

\section{Jobskabelse}

Eksporten af nordiske brugte tekstiler er vurderet til at skabe cirka 1.500 fuldtidsstillinger inden for sortering, 2.000 inden for engros og 5.500 i den regulerede detailsektor i modtagerlandene.

Antallet af familier som støttes af den uformelle sektor i udviklingslande kan være endnu højere. De omkring 12.000 tons nordiske tekstiler, som eksporteres til det afrikanske kontinent alene, er estimeret til at støtte mere end 10.000 markedssælgere og deres familier.

Hvis handlen med brugte tekstiler erstatter handlen og produktionen af nye tekstiler i modtagerlandene, kan netto jobskabelsen være lavere.

\section{Potentialet for "Code of Conduct"}

De samme stramme økonomiske vilkår, som sikrer at alle fraktioner af brugte tekstiler anvendes fornuftigt, kan også tilskynde ejerne af sorteringsanlæg til at betale lav løn og springe over, hvor gærdet er lavest i forhold til helbred og sikkerhed. 
En mulig løsning kan være at pålægge køberne af de nordiske indsamlere en "Code of Conduct" CoC. For at CoCs har en effekt, bør der føres regelmæssigt tilsyn med implementeringen. Der, hvor sådanne CoCs er indført, finder man forbedrede arbejds-, helbreds- og sikkerhedsvilkår i værdikæden. Dog har CoCs et mere begrænset potentiale i den uformelle sektor.

Selvom økonomi på nuværende tidspunkt sikrer, at genbrug og genanvendelse prioriteres, kan CoCs også blive et vigtigt redskab i forhold til at sikre at affaldshierarkiet overholdes, hvis de økonomiske forhold skulle ændre sig.

\section{Effekter på den indenlandske tekstilindustri}

Brugte tekstiler fra Europa og andre udviklede lande udgør en vigtig kilde til beklædning for en betydelig del af befolkningen i subsaharisk Afrika. Mere end halvdelen (målt ift. værdi) af de importerede tekstiler til Kenya, Ghana, Rwanda, Uganda, Tanzania og Malawi er second-hand. Andelen målt i vægt er formentlig langt højere.

Brugte importerede tekstiler forsyner dem, der ellers ikke ville have haft råd, med billige klæder af god kvalitet. På den anden side kan disse importerede tekstiler også bidrage til et fald i den indenlandske tekstilindustri i disse og andre lande syd for Sahara.

Ikke desto mindre kunne nedgangen i den indenlandske tekstilindustri være forekommet selv i fraværet af genbrugssektoren. Der er beviser på, at ældre og ineffektive indenlandske industrier har været ude af stand til at konkurrere med produktion i Asien efter handelsbarrierer blev fjernet i slutningen af 1990'erne og begyndelsen af 2000'erne. Import af både brugte og nye tekstiler er steget drastisk siden 2000 på tværs af subsaharisk Afrika. Der er ingen beviser for, at en mangel på brugte tekstiler ikke blot vil føre til yderligere import af billige nye tekstiler fra Asien.

\section{Importrestriktioner}

Dele af subsaharisk Afrika samt andre lande i andre dele af verdenen forsøger at hæmme import af brugte tekstiler via forbud, restriktioner eller voverkommeligt høje skatter.

Sådanne restriktioner kan være et plaster fremfor en reel løsning på nedgangen i den lokale industri. Forbuddet i Syd Afrika har ikke standset nedgangen i den indenlandske industri. Import af nyt tøj til Sydafrika per indbygger er ti gange højere i værdi end den totale import af nyt og brugt i de andre nævnte lande og er hurtigt stigende. Dertil kan forbud og restriktioner på brugte tekstiler have negative decideret bivirkninger. Handlen kan stadig fortsætte, men via ulovlige kanaler, som vil medføre et 
indtægtstab i form af importafgifter. Forbud vil også skade second hand sektoren, som mange regeringer fastslår er en vigtig fattigdom-reducerende aktivitet. Det er relativt let at starte op som markedssælger af brugt tøj og sektoren i subsaharisk Afrika og andre steder har trukket titusinder af familier ud af fattigdom.

Påvirkningen af den indenlandske tekstilindustri kan i stedet reduceres ved at fokusere på produktion til eksportmarkedet, ved at specialisere sig i bestemte typer af tekstiler og ved at investere i moderne udstyr og processer, som tillader industrien at konkurrere på det globale marked. Dette vil kræve betydelige investeringer, som i udviklingslande kan være nødvendige at tiltrække andre steder fra.

\section{Anbefalinger}

\section{Anbefalinger til nordiske indsamlere/eksportører af brugte tekstiler:}

- Tilpas eller vedtag et "Code of Conduct" for egne aktiviteter og for deres købere, med vægt på:

- Arbejdsvilkår.

- Mål for andelen af genbrug og genanvendelse.

- Rigtig behandling af resterende affald.

- Effektiv og regelmæssig tilsyn, rapportering og opfølgning.

- Understøt så vidt muligt eksisterende købere i at opfylde disse krav fremfor at skifte købere, hvis kravene ikke overholdes.

- Hvor det er muligt, prioriter købere med egen detailhandel fremfor grossister for at forbedre eller forenkle sporbarhed.

- Hvor det er muligt, plej langvarige forhold til købere for at sikre at eksporten er tilpasset behov og affald undgås.

- Fjern åbenlys tekstil- og ikke-tekstil-affald fra original forud for eksporten.

- Begræns eksport af original til sortering i EU-og EEA-lande.

- Undersøg muligheder for at støtte bedre indsamling og behandling af postforbruger tekstiler i udviklingslande.

- Indgå i projekter med det formål at øge efterspørgsel for genbrug og genanvendelse inden for nordiske grænser. 


\section{Anbefalinger for nordiske policymakers}

- Udvikl retningslinjer for indsamlere og eksportører om fortolkning af nationale, europæiske og internationale regulativer for transport af brugte tekstiler.

- Bistå med den videre udvikling og opfordr til indførsel af Nordisk Ministerråds pilot "Code of Conduct" blandt indsamlere.

- Bistå udviklingslande med at forbedre systemer til indsamling og behandling af husholdningsaffald.

- Etabler strategier, opstartsprojekter, puljer til finansiering af innovation mv. for at fremme stærkere markeder for genanvendelse og genbrug af tekstiler på nordiske markeder, dog uden at gå på kompromis affaldshierarkiet.

- Fortsæt og øg støtte til øget indsamling af brugte tekstiler både for de nordiskeog eksport markeder. 



\section{Appendix A: Direct exports of used textiles according to UN Comtrade data}

The table below presents all countries receiving over 50 tonnes of worn textiles and clothing (CN code 6309) from the four Nordic countries included in the study in 2014 (data behind Figure 5 in main text). The table gives the weight and value of the textiles received by each country.

Table 11: All countries receiving direct exports of worn textiles and clothing from Nordic countries, 2014

\begin{tabular}{|c|c|c|c|c|c|}
\hline Receiving country & $\begin{array}{r}\text { Weight of } \\
\text { textile im- } \\
\text { ports } \\
\text { (tonnes) }\end{array}$ & $\begin{array}{r}\text { Value of } \\
\text { textile } \\
\text { imports } \\
\text { (US dollars) }\end{array}$ & Receiving country & $\begin{array}{r}\text { Weight of } \\
\text { textile im- } \\
\text { ports } \\
\text { (tonnes) }\end{array}$ & $\begin{array}{r}\text { Value of } \\
\text { textile im- } \\
\text { ports } \\
\text { (US dollars) }\end{array}$ \\
\hline Poland & 18,850 & $15,156,594$ & Tunisia & 262 & 2,1805 \\
\hline Lithuania & 11,410 & $9,617,812$ & Philippines & 262 & 307,255 \\
\hline Bulgaria & 6,551 & $4,471,560$ & Bosnia Herzegovina & 250 & 341,815 \\
\hline Estonia & 6,214 & $4,566,084$ & Russian Federation & 195 & 807,297 \\
\hline Germany & 5,866 & $3,654,375$ & Algeria & 172 & 170,199 \\
\hline Turkey & 4,070 & $3,025,987$ & Rep. of Moldova & 150 & $104,75^{8}$ \\
\hline Belgium & 3,569 & $2,715,138$ & Angola & 136 & 134,654 \\
\hline Netherlands & 2,346 & 236,424 & Serbia & 124 & 132,104 \\
\hline Slovakia & 2,147 & $2,205,774$ & Kazakhstan & 124 & 625,746 \\
\hline Pakistan & 1,410 & 915,597 & Tanzania & 101 & 99,964 \\
\hline Romania & 1,298 & 194,006 & Jordan & 93 & 29,708 \\
\hline Malawi & 1,273 & $1,216,594$ & Uganda & 91 & 44,417 \\
\hline Ukraine & 955 & 743,215 & Hungary & 85 & 77,250 \\
\hline Latvia & 935 & 955,549 & Albania & 84 & 65,970 \\
\hline Somalia & 657 & 407,332 & Cte d'Ivoire & 76 & 99,275 \\
\hline UAE & 563 & 375,211 & Chile & 74 & 30,564 \\
\hline Ghana & 501 & 446,358 & Sierra Leone & 68 & 256,189 \\
\hline Czech Rep. & 469 & 561,046 & Mongolia & 67 & 527,234 \\
\hline Mozambique & 441 & 413,198 & United Kingdom & 65 & 76,697 \\
\hline India & 362 & 48,490 & Lebanon & 62 & 51,450 \\
\hline Iraq & 305 & 349,998 & Togo & 61 & 22,123 \\
\hline Gambia & 297 & 225,484 & Syria & 51 & 74,317 \\
\hline Belarus & 268 & 96,885 & & & \\
\hline
\end{tabular}


The graphs below show the key receiving countries for direct exports of worn textiles and clothing from the individual four Nordic countries in 2011 and 2014. The data has been extracted from the UN Comtrade database. 
Figure 21: Nordic exports of worn textiles and clothing, 2014 (only countries receiving over 50 tonnes are shown)

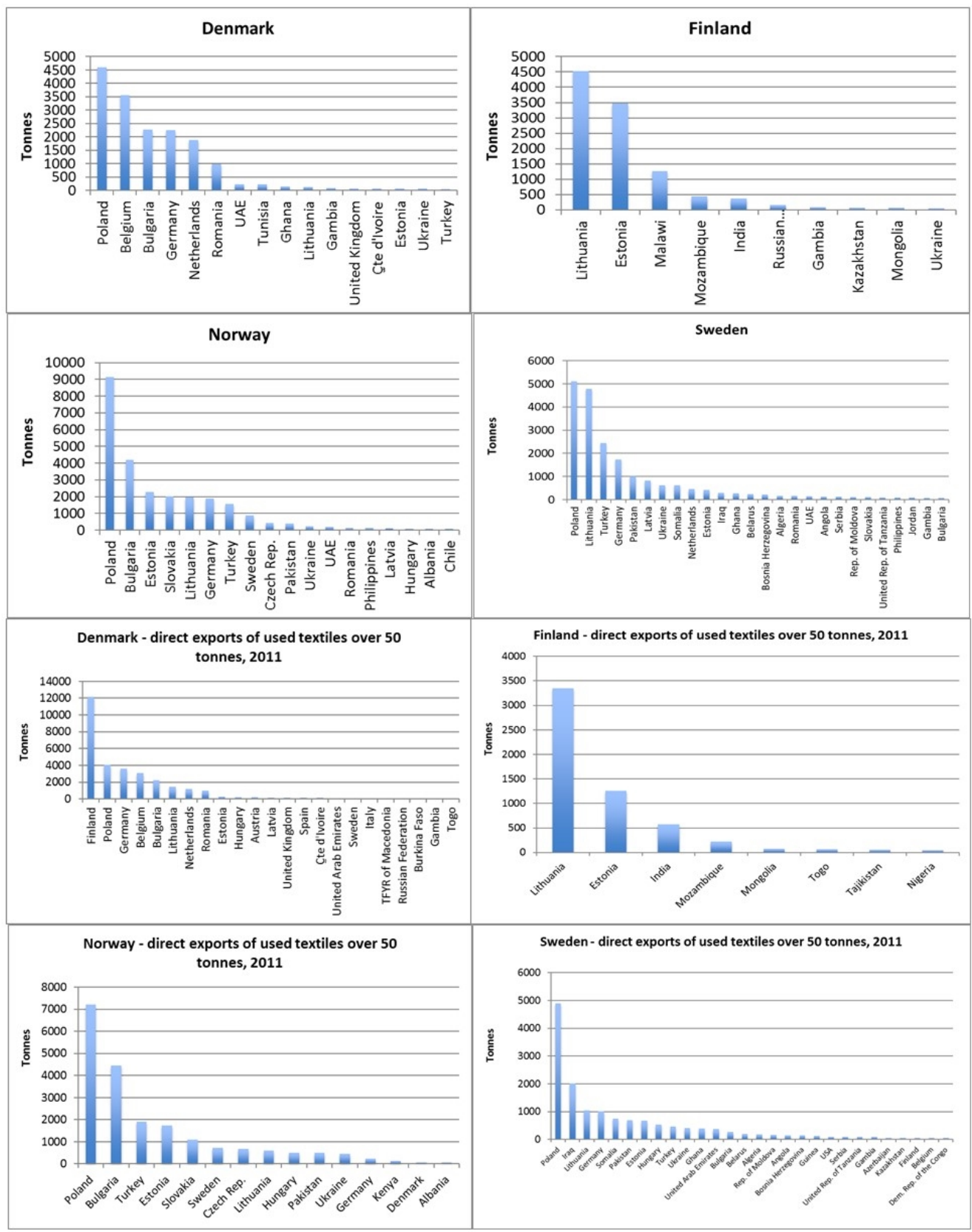

Note: These graphs identify the first receiving country after leaving the collection country. Much of the textiles may well be re-exported again from the initial country following sorting. 



\section{Appendix B: Malawi country study}

\section{Reason for Selection and Study Methodology}

Malawi was chosen as one of the three study countries as it represents the largest receiver of used in Africa of textiles originating in the Nordic countries, both via direct import and also indirect import via interim countries where the Nordic textiles have been sorted. Malawi has no restrictions on imports of used textiles. The specific focus of the study in Malawi is to document the textile flow and the economic, social and environmental benefits and impact of the imported used textiles. Moreover, by also carrying out investigations in nearby countries with string restrictions on textiles such as South Africa and Zimbabwe there was potential to make a comparison with the situation in Malawi with no restrictions in place.

This country visit report is mainly based on information collected during a study tour to Malawi and South Africa carried in early April 2016. In addition to the interviews and site visits the country report also refers to relevant documentation received during the visit, and identified via desktop study.

The visit to Malawi was organised in close cooperation with the Humana organisation in Malawi Development Aid from People to People (DAPP). DAPP has after 20 years of activity in Malawi and a very mature contact network. Based on the specified needs of the visit, DAAP set up meeting appointments and site visits (see Table 1 and Table 2). 
Table 12: Overview over site visits in Malawi

\begin{tabular}{llll} 
Organisation & Type of organisation & Contact person & Position \\
Exlusive Fashion, Blantyre & Textile manufacture & $\begin{array}{l}\text { Muhammed Than- } \\
\text { du Miah }\end{array}$ & er \\
Crown Fashion, Blantyre & Textile manufacture & Vijay Kumar & $\begin{array}{c}\text { Chief Executive } \\
\text { Officer }\end{array}$ \\
Trade Fair Wholesale centre, Blantyre & Wholesale 2. hand & Anon \\
$\begin{array}{l}\text { DAPP retail shop, Limbe } \\
\text { DAPP retail shop, Blantyre centre }\end{array}$ & Retail shop 2. hand & Anon \\
DAPP sorting centre, Blantyre & Sorting Centre & Anon \\
DAPP, wholesale, Thyolo & Wholesale & Anon \\
X-power Kaunjika, Lilongwe & Wholesale & Anon \\
Informal market seller at Chilobwe & Market sale family (include home \\
market and home visit & visit in private house) & Anon \\
Market costumer at Thyolo market & Second hand and new clothes & Anon \\
Market costumer at Limbe market & Second hand and new clothes & Anon \\
\hline
\end{tabular}

In addition two of DAPP social projects based on surplus from used textile activity were visited, one Woman Farmer Club in Dowa and a teacher school in Mzimba.

Table 13: Overview of meetings held in Malawi

\begin{tabular}{lll} 
Organisation & Contact person & Position \\
\hline $\begin{array}{ll}\text { Ministry of Labour, Youth and Manpower development } \\
\text { Ministry of local Government }\end{array}$ & Hon. Henry Mussa & Minister \\
Ministry of natural resources, energy and mining & Hon Kondwane Nankumwa & Minister \\
Ministry of trade and Industry & Hon. Bright Msaka & Minister \\
ILO & Kendlo Chisale & Chief economist \\
Industry ALL Global Union & Naomy K. Lintini & Chief Technical Advisor \\
& Amos Harry Chasowa & Project coordinator \\
\hline
\end{tabular}

The trip included two days in South Africa. This was organized by Mepex together with Department of Trade and Industry in Pretoria. Table 3 gives a list of organisation present at a meeting held in on 5th April. In addition a meeting was held in Zimbabwe with the Chairman of the Federation of Associations connected to the International Human People to People Movement whose main office lies in Harare. 


\begin{tabular}{lll} 
Name & Position & Organisation \\
$\begin{array}{l}\text { Noncedo Mviko } \\
\text { Dimakatso Moji } \\
\text { Marius Collins }\end{array}$ & TDI Department of Trade and Industry (TDI), Industrial Development Division \\
$\begin{array}{l}\text { Abisha Tembo } \\
\text { Phemelo Marishane }\end{array}$ & $\begin{array}{l}\text { TDI rep. in SADC } \\
\text { TDI rep. in SACU }\end{array}$ & $\begin{array}{l}\text { ITAC (International Trade Administration Commission } \\
\text { South African Development Community } \\
\text { South African Custom Unit }\end{array}$ \\
\hline
\end{tabular}

The findings from the interview are also compared with other sources of information in order to attempt to ensure unbiased results.

\section{Volumes and types of textiles imported to Malawi (and South Africa)}

According to the UN's import/export database the volume of worn clothing (code 6309) into Malawi increased from 5,000 tons in 2004 to 19,000 tons in 2014. The total volume for worn clothing from export statistics seems reasonable based on the local market analysis. The Malawi Revenue Authority indicates an import of worn clothes in the range 15-22,000 tons/year.

In general, there has been an economic stagnation over the past five years with high inflation and devaluations. The situation got worse in 2014 after a corruption scandal that reduced government funds by USD 60 mill. In 2015 the floods caused a very bad harvest and farmers that represent about $65 \%$ of labour lost most of their income.

Imports of rags (product code 6310) are low lying at around 200-300 tons annually. These are thought to comprise industry wipes.

The UN database import figures reported by the Malawian customs are substantially higher than those reported by countries exporting to Malawi. These seem to be out of kilt with the understanding of the market. The reason for the significant difference between trade in used clothes reported by Malawi's trade partners and by Malawi itself have not been investigated in detail. Particularly high differences are found for imports from China and Pakistan. One possibility is that false values have been given by the local customs authorities to increase import duty payments. 
Figure 22: Export of worn clothes to Malawi, 2000-2015

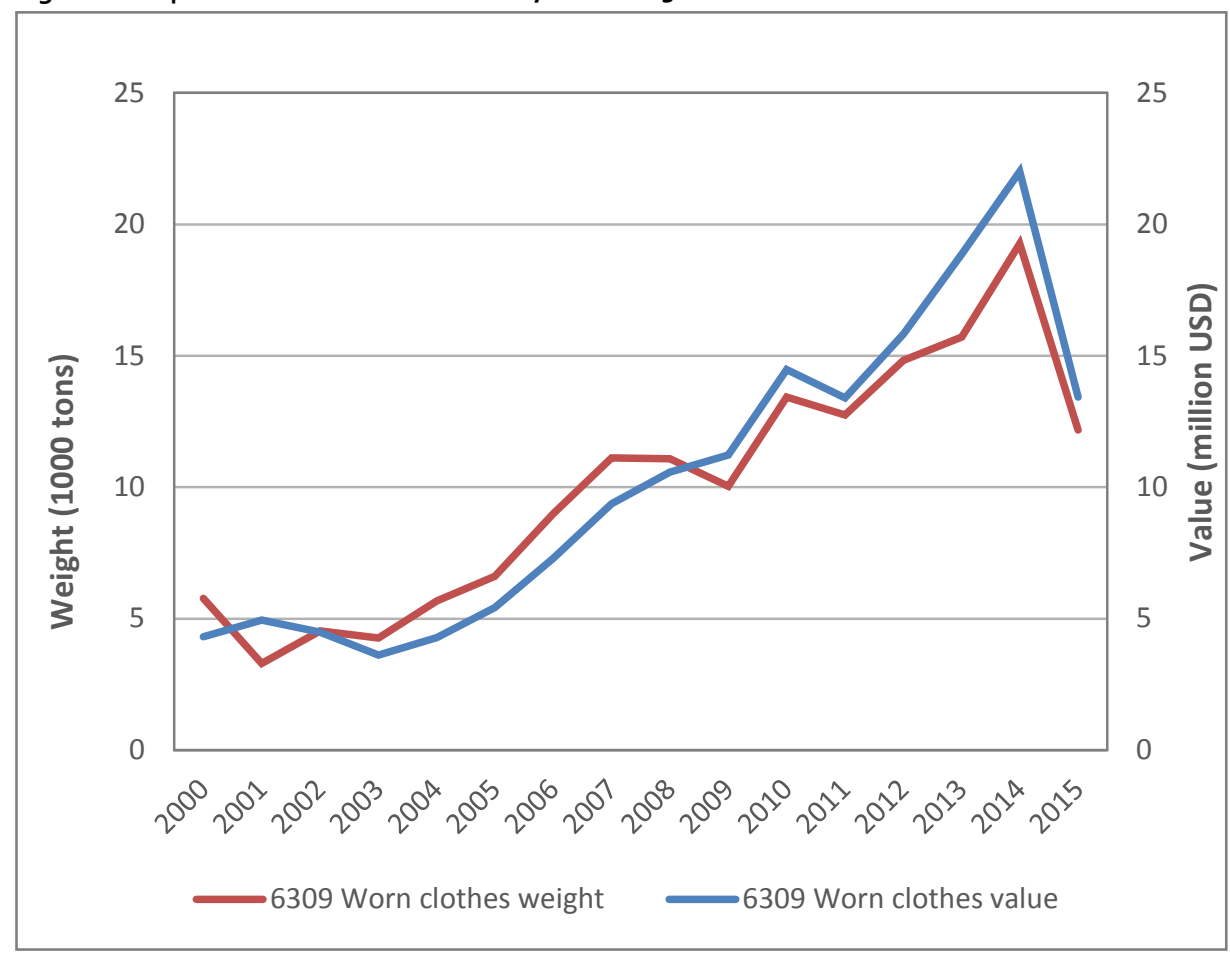

The total trade value of the imports increased from below USD 5 million in 2004 to USD 22 million in 2014 at current prices, before dropping to under USD 14 million in 2015. The average import value is about USD 1.1/ $\mathrm{kg}$ in 2014 according to UN statistics. There are variations in the import value that not easily can be explained.

The prices of all goods in local markets have increased since 2013 due to high inflation and depreciation of local currency. This could have led to a higher demand for second hand clothes since these are cheaper than new, but in 2015 widespread flooding cause a further deterioration with no income from harvests and 3 million people facing starvation. Then this reduced the market for second-hand clothes as many could not even afford these. 
Figure 23: Top exporters of worn clothing and other textiles to Malawi, 2014

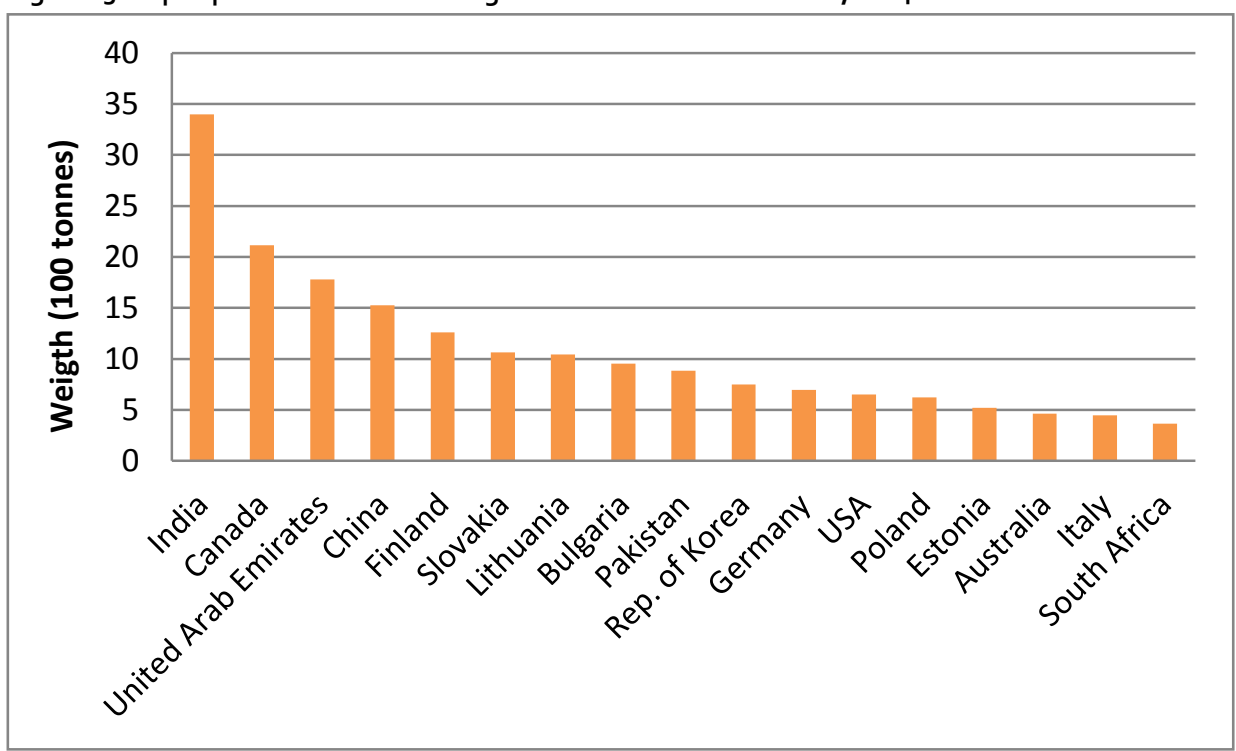

India, Canada, the UAE and China are important exporters of worn clothing to Malawi, according to UN data (see Figure 2). The middle part of Malawi including Lilongwe is strongly influenced by Muslims developing business in Malawi, and importing second hand clothes from Asia. There is import from Canada and USA and UAE may be a transit country for export from USA.

Amongst the Nordic countries only Finland directly exports used textiles to Malawi in any significant quantities (approx. 1,300 tons in 2014). The Phase 1 mapping identified direct exports of just over 600 tons to Malawi from the 13 largest Nordic collectors (all via UFF Finland). This is significantly less than the direct export from Finland reported by the UN. The reason for the discrepancy isn't known.

Malawi also received Nordic textile indirectly via sorting facilities typically located in Eastern Europe. DAPP for example receives sorted textiles from Humana organisations in Lithuania, Slovakia, Bulgaria and Estonia that include textiles from the Nordic countries.

The Phase mapping identified approximately an additional 800 tonnes of Nordic textiles imported to Malawi via interim countries to give a total import of 1,400 tonnes. The total quantity of used textiles entering Malawi originating in the Nordic countries is likely to be higher. A good share of the 5,500 tons of Nordic textiles entering the African continent with unstated destination identified under Phase 1, probably ends in Malawi. At a rough estimate the Nordic textiles represents about $10-15 \%$ of 
total imports of used textiles to the country making the Nordic region an important actor in the Malawian second hand sector.

All textiles originating in the Nordic countries and ending in Malawi are sorted tropical and grade A quality fit for sale and reuse. As already mentioned all sorting take place in Finland and intermediate countries in Eastern Europe. Figure 3 shows the UN database data for export of worn clothing (code 6309) into South Africa. This is reported to lie at approximately the same level as Malawi, at 19500 tons in 2014. This import is mainly from USA and West European countries (Netherlands, Italy, Germany). This high level of reported import is despite a long term strict import ban and control. The import restrictions do not apply to donations or winter coats but it is felt unlikely that these could comprise more than 19,000 tonnes. No explanation has been found for these high figures.

In addition there is a close to constant import of rags up to 4,600 tons. This is the level of the maximum quota reported by ITAC for import of rags to the recycling industry in South Africa. 63 companies have been issued quotas for receiving these imports which mostly comprise industry wipes.

\section{Overview of process routes for textiles}

Second hand textiles play an important role in the overall supply of textiles to the nation. Second hand is purchased by a large part of the population, allowing access to quality for those that can't afford to buy new, and generating jobs in the formal and informal sectors. Different interview sources estimated that about $90 \%$ of population can only afford second-hand clothes.

Most imports of used textiles to Malawi arrive in shipping containers of bales wrapped in plastic film containing textiles of different sizes and quality. One container can include 20 tons of textiles. Big bales normally weigh $400 \mathrm{~kg}$, but smaller bales of about $50-80 \mathrm{~kg}$ are imported. All bales inspected were marked with information that identifies company, country of origin and quality.

Several interviewees reported also that there is an activity connected to re-marking and wrapping used textiles in new plastic in order to look like imported original.

DAPP imported 4790 tons of textiles (and shoes) in 2014 reducing to 3,370 tons in 2015. The $30 \%$ reduction came in response to lack of demand resulting from the economic recession in the country. Normal quality imported by DAPP is tropical mix, shop return and tropical mix extra (blended with A-quality). 
The process routes for imported used textiles for reuse in Malawi are shown in Table 4, mainly based on those reported by DAPP. We expect that routes are similar for other used textiles originating in the Nordics, though not including local sorting and retail shops.

Table 15: Steps along the route from import to resell

\begin{tabular}{|c|c|c|}
\hline & DAPP (Humana) & In general \\
\hline Importers & $\begin{array}{l}\text { DAPP import from their suppliers in Europe and } \\
\text { Turkey and Oman }\end{array}$ & $\begin{array}{l}\text { The number of importers is unknown, but } \\
\text { many of the importers are based in Asia and } \\
\text { Lebanon }\end{array}$ \\
\hline Sorting centres & DAPP have one official sorting centre in Blantyre & No other reported \\
\hline Wholesale shops & $\begin{array}{l}\text { DAPP has } 10 \text { wholesale shops all over the coun- } \\
\text { try, also in rural districts }\end{array}$ & $\begin{array}{l}\text { There are a lot of wholesales concentrated } \\
\text { around the cities. }\end{array}$ \\
\hline Repair/retail shops & $\begin{array}{l}\text { DAPP has } 21 \text { regular shops selling about } 25 \% \text { of } \\
\text { imported volume. Some repair activity in shops. }\end{array}$ & $\begin{array}{l}\text { There is a lot of small business based on } \\
\text { repair and refurbishing }\end{array}$ \\
\hline Open market sale & $\begin{array}{l}\text { DAPP have about } 3000 \text { costumer buying bales } \\
\text { for own business. }\end{array}$ & $\begin{array}{l}\text { In all kinds of market places you find open } \\
\text { market sale for second hand clothes }\end{array}$ \\
\hline
\end{tabular}

DAPP divide the market in three regions, and according to own calculation DAPP has close to $1 / 3$ of the total market in Malawi. DAPP is the only charity organisation in the country working with second hand clothes. The rest of the second-hand sector is commercially run.

Table 16: DAPP market shares

$\begin{array}{lrr}\text { Region } & \text { Market volume } & \text { DAPP market share in the region } \\ \text { South } & 50 \% & 50 \% \\ \text { Middle } & 40 \% & 10 \& \\ \text { North } & 10 \% & 50 \% \\ \text { Total } & 100 \% & \end{array}$

\section{Sorting centres}

DAPP is one of the big importers to the country, and based on our sources the only organisation with own sorting centre for used textiles in Malawi. This is located in Blantyre. About $75 \%$ of their import is sorted locally, the rest sold directly as bales, mostly $45 \mathrm{~kg}$ tropical mix. 
In the sorting centre the textiles are sorted in up to 83 different categories, before the textiles are folded, graded and packed and in smaller bales from $15-45 \mathrm{~kg}$.

The idea with the sorting is to meet the different demand for different qualities in the market and offer small units so there is easier for poor people to start up a small business without capital. Many specialise in a single category of clothes.

Almost the entire volume arriving at the sorting centre is suitable for reuse. Rejects identified during sorting is reported to be $1 \%$. This reject is sold to companies that can utilise this for refurbishing, repair, wipes, and so. A sales price of USD $0.4 / \mathrm{kg}$ is reported for rejects.

In general, we can assume that all imported qualities to Malawi are suitable for reuse and more importantly have been correctly selected in the exporting country to be suitable for the African market and the local demand for quality. This was confirmed by interviews and visits to other market players than DAPP. There is no indication, whatsoever, that Malawi is a dumping place for low quality used textiles.

\section{Reuse}

As noted above almost the entire import is resold for reuse in the country, in some cases following sorting. Resale occurs via retail shops or via market sellers mostly running on the informal market (see later). Market sellers obtain the used textiles via wholesale merchants.

DAPP has ten wholesales departments for second hand clothes and shoes (down from 15 a few years ago). Transport to the wholesales shops are partly organized via DAPP's own trucks, but also using transport companies. All wholesales have their own budgets and the sale is strongly depending on the seasons and income from harvesting.

Prices at wholesale differ upon quality and size of bale. A $45 \mathrm{~kg}$ bale of children's clothes can cost USD 175 i.e. USD 4/kg. Of this approximately $40 \%$ can be profit. A 15 $\mathrm{kg}$ bale of t-shirts can cost about USD 30 or USD $2 / \mathrm{kg}$. Wholesalers also offer transport services to the market seller if coming from a distance.

DAPP alone has 20 retail shops. These shops are based on a 2-week cycle system, whereby clothes and shoes are delivered to a retail shop and sold within two weeks. All items have a specific price put on by the shop manager, based on the local market situation. After the first week with fresh clothes, prices are reduced so that by the last day the shop is empty with everything sold. In the last days some of the sales are to market sellers that can buy for a very low price. New clothes are put on hangers every day sorted in categories and colours. 
The system is the same in many European countries, but where four week is more normal. All shops have their own budgets and register the sale every day.

The greatest volume of sale in second hand is via the market places. There the sale is mainly based on informal business. This is a legal form of sale and the enterprises pay a market tax per day to local authorities.

All kind of clothes, shoes, towels, bed linen, blankets, so are sold in these market places. There are specialized outlets and outlets with all kinds of clothing. The market sellers are looking for good quality and normal styles. The costumer can make their choices and are free to choose from wholesalers according to own needs. In general the quality we observed during the site visits was good. It's too simple to state that lower quality is exported out of Europe.

Prices are typically $25-50 \%$ of the prices for equivalent new cheap imports from Asia. As an example the price for a new imported T-shirt was USD 4-7 while the price for a second hand T-short was around USD 1.2-1.7.

The price difference depends on quality both of the new clothes and the used items. Several interviewees told us that the quality of import of new clothes is very low and that they have a very short lifetime. The general impression is that buying second hand is a better choice due to higher quality at lower prices.

Typically everything is sold from both retailers and market sellers. Items attracting little interest are simply sold at low prices. The interviewees in the retailers and markets didn't report having had textile waste that they had to dispose of. We saw no evidence of textile dumps or littering of waste textiles at market during our visits.

All types of people buy second hand and second hand purchases are accepted in all parts of society. For most people the second hand market fills a gap in demand that new textiles can't fill. Typical tropical mix contains about four clothing items per $\mathrm{kg}$. So the total annual import of around 20,000 represents 80 million items of used clothes or roughly five items per capita. This fits with findings from interview with people in rural areas ( $80 \%$ of population). The UN's identifies a minimum level of need at eight items per year. Therefore, the imports of second hand provides under the minimum needs of society but a good share of it.

\section{Recycling}

No industrial recycling of textiles was named during interviews. There are small streams of textile waste from second hand sorting from DAPP (40-50 tons/year) and from the new textile industry rough estimated at 50-100 tons/year). These waste streams have a 
positive value and are sold and utilised for repair, refurbishing, wiper production. Small informal businesses can find ways to utilize the value of all the residual products.

\section{Waste}

As described above the used textile sector doesn't generate much, if any waste. All imported textiles have a value and we found no evidence of dumping of textiles due to low quality. Plastic used for packing bales also have a value and are collected for recycling.

Looking further along the lifecycle of the imported used textiles, what happens to them once the new owner has finally worn them out?

The general waste management system in Malawi is not well developed. According to the Minister responsible for waste management, the will is there, but funds are lacking for investments in infrastructure for waste management.

In the cities there is partly a system for waste collection, both based on municipal services and private enterprises. The cost is covered in a general city tax. Not many waste bins was observed in the cities visited, especially Blantyre and Lilongwe. Waste pickers were in some cases more or less emptying the bins for anything of value for recycling or reuse. Littering and small waste dumps were registered, but not any open fireplaces. According to a Master's study carried out in 2014 only about $30 \%$ of waste in Blantyre and Lilongwe are collected. It is likely that waste collection in rural areas is even lower but $94 \%$ of household waste in rural areas is organic (Barre 2014).

Some of the collected waste is dropped in open landfills. We visited a municipal landfill outside the capital Lilongwe. The landfill was uncovered and probably with no real lining and little control of leakage water.

The rest, over 60,000 tonnes a year in each of these cities accumulates, some is picked by waste pickers (see below) while some households burn their waste on open fires to avoid it accumulating and smelling. Some waste companies also use open burning of waste as a common practice after the valuable recyclable elements (plastic, glass and paper) have been removed and the organic element composted. Compost has recently begun to gain value in the country and a number of companies have been started up in recent years to begin composting organic waste collected by waste scavengers amongst others (Barre, 2014).

Malawi has a large informal sector of waste pickers/scavengers who collect anything of value from household waste and open waste dumps (Barre, 2014). One of the waste scavengers living at the landfill we visited was interviewed and told us that they mainly picked plastic, metals and glass for reuse and recycling. A lot of glass bottles 
shops, plastic waste and scrap metals dealers were seen along the roads, but not any textile waste shops.

A lot of waste was dumped along the access road to the landfill, but again textile was not a part of that.

Based on the pieces of information we can set up a rough estimate for the destiny for textile usage in the country:

- $10 \%$ ending up in open low-tech landfill tips (30\% of waste from urban areas).

- $20 \%$ is locally disposed in urban areas after reuse as cloths, mops.

- $70 \%$ disposed of in rural areas after reuse as cloths, mops and so on. Some of this final textile waste is probably burnt while the rest.

There is a lack of infrastructure for waste in general, but a high focus on the material value of products gives textiles a very long life until all the possible value is drawn out of them after which they are probably burnt or perhaps disposed of in nature.

\section{Employment and output in the used textile sector}

Malawi has about 15 million inhabitants, is one of the countries in Africa with high population density and is one of the poorest countries in the world with $65 \%$ of the population living in poverty.

The total value of textiles imported to Malawi at the border was about USD 22 mill in 2014, representing about USD 1.2 per kilo. This have a tax revenue on $25 \%$ duty and $16.5 \%$ VAT.

The average sale price in DAPP's retail shop is between USD 2-3 per $\mathrm{kg}$, so the value is approximately doubled. However, high inflation and a weak economy over the past two years has reduced the real income from second hand sales. DAPP's surplus from sale of textile was USD 1.3 million in 2013, before the current economic downturn. All surpluses have been used in development and aid projects in Malawi and have been a very important element in the total financing of the activity.

DAPP directly employs 280 staff in the processing and sale of textiles:

- Sorting - 2.5 employees per 100 tonnes per year.

- Wholesale -4 employees per 100 tonnes per year.

- Retail shop-14 employees per 100 tonnes per year. 
Scaling this up to similar work at other importers we estimate approximately 1000 jobs across the country in import, sorting, transportation and wholesale.

Further downstream are the market sellers of second hand clothe. DAPP alone has about 3,000 market sellers regularly buying second hand clothes for resale, and it's reasonable to assume 2-3 working people (often family members) per seller. Scaling this up to the Malawi second-hand market as a whole we estimate around 20,000 employed in small informal businesses. This represents about one tonne per person per year or about 45 kilo (one bale) per 14 days which is a typical sales quantity for a market seller.

Every job in this field will be the main economic contributor in the family economy. We interviewed some of the market sellers and they reported that 10-15 people can be supported from the profit from a single second hand outlet, including orphans. The various Ministry staff interviewed underlined the important role second hand clothes have for the economy, employment and to give better living conditions with cheap clothes of good quality.

Working conditions in DAPP organisation seems in general to be very good with regulated working hours, salary high over the minimum wage and a good working environment. Normal salary in DAPP was reported to about USD 57 per month, including food costs which is more than double the minimum wage. All workers have written agreements and are free to join any union. About 50 workers in DAPP are organized in Unions. The staff turnover is very low in the organisation many have been working for many years, an indication that staff are content with the working conditions.

It is not clear what working conditions are like in the rest of the second hand sector. The country has ratified the eight core ILO Labour Conventions and workers have the right to form and join trade unions. In addition, the Employment Regulations of 1999 accords workers rights to paid leave, maternity leave and sick leave (van Klaveren et al., 2009). Moreover, child labour under the age of 14 is forbidden and there is a minimum wage set albeit set just above the poverty line.

However, most of the employment in the second hand clothing is informal and therefore not covered by any of these rules and regulations. Second hand activity is mainly restricted to wholesale and market sale and often organised in small family based entities making a living based on second hand clothes. DAPP is the only importer that also runs a chain of wholesales and retail shops.

The open market outlets are part of the informal sector without any tax payment and labour regulation or control. The informal economy has experienced a rapid expansion. This "sector" has a large number of young people and more women than men, and is characterised by worse working conditions both in form of less income, no social protection and work safety or representation. It is estimated that the informal 
economy covers $89 \%$ of the total labour force of the country, which is a size similar to other neighbouring countries. Child labour is widespread in the informal sector and remains a serious problem in Malawi. An estimated $26 \%$ of the total labour force are children (Danish Trade Union Council, 2014).

The risk for poor working conditions in the value chain of second hand clothes may be lower than other part of the informal sector. Certainly no child labour was noted during site visits. The second hand sector also gives employment opportunities for women: under the visit we mainly saw women working with second hand clothes, while textile factories comprised mostly male workers.

In the formal sector in Malawi the national minimum wage is set to about USD 1 per day, equal to the UN definition on limit for poverty. According to statistics about $65 \%$ of population live in poverty, but this doesn't take account of the informal sector's important role.

Interviews with government representatives in the country emphasised the important social and economic benefits of the second hand activity. The Minister of Labour referred to the important employment in small enterprises: the second hand clothes sector creates jobs and make it possible for people to start up small scale business that are able to sustain themselves and their family. The minister of local government underlined that the second hand textile sector was an important tool in poverty reduction and in providing access to affordable clothing; the second hand sector fills a gap for those that cannot afford new.

\section{Codes of conduct and social programmes}

DAPP (Humana) operates as a charity and follows a code of conduct based on their standards. However, the code of conduct is not formally written down and it's mainly based on internal control so there is in fact no guarantee that it is being followed in all parts of DAPP's operations. In general the following requirements are met:

- Compliance with all relevant legal requirements based on national laws and regulation, including requirements for environment and social and working condition.

- Paying taxes and VAT (also in retail shops that are in competition with market sales without any taxes and VAT).

- Working agreements that ensure regulated working hours, no children workers, good salaries, sick-leave money, relevant insurance and free to be organized in unions. 
Other market importers are commercial companies and are expected not to have implemented a code of conduct. There is no information about possible export of used textile with origin from Nordic market that have requirements relevant for $\mathrm{CoC}$.

With respect to charitable activities, DAPP Malawi has an operation in Malawi with more than 900 staff, mainly raising funds for all programs and project though selling second hand clothes, also from donations from member organisations in Nordic countries and Europa in general. The projects mainly cover agriculture, education and health and community development in general.

In some cases DAPP has donated clothing in specific aid situations, normally connected with their own social programmes. This can also include provision of textiles to refugees living in camps inside Malawi. In general the direct social effect from DAPP operating the textile activity in Malawi is connected to the generation of 280 jobs based on local resources. These jobs support many families.

DAPP seems to have good programs and systems to development the skills for their employee that gives positive effects. DAPP is also providing support for market sellers out in the field and making good networks for exchanges of experience.

The visit in Malawi included a trip to two projects operated by DAPP. We visited a teacher school with 120 students following a 3 years program. The teachers students are educated to be independent and to obtain practical skills for important in all rural communities. The important of local utilization of resources is underlined also for education purposes.

We also visited a farmer club organised as a cooperative with 4 ooo members (family farmers). The cooperative organized sale for all members and had an own production of soya milk and peanut butter.

\section{The textile industry in Malawi and South Africa}

Our knowledge on the textile industry in Malawi is based on contact with two textile factories who have been in the business for a long time and have experienced a decline in their businesses. In addition the development was discussed with ILO, relevant Labour Unions and representatives from the Ministry of Labour and the Ministry of Trade and Industry.

We have also used data from National Statistics Office Malawi and other sources of information on web. There is not possible to give continues picture of the development in the industry and different sources are not always comparable. A lot of all employment you find in informal sector and a study from 2014 give a number that $88 \%$ of total employment is in the informal sector (Malawi National Office of Statistics, 2013). 
The textile industry was reported to have about 10500 employees in 1998, but by 2011 the number was down to 3300 . This represents about $10 \%$ of all manufacturing in the country.

The textile industry is mainly producing for export. However, export has also declined. Exports under AGOA (African Growth and Opportunity Act) agreement was on USD 13,5 million in 2011, but had declined to about USD 4 million by $2014 .{ }^{17}$

The situation is likely to have worsened since $2014-2015$. No official data was found for that period but we can expect that there are not more than ten factories left, with about 2,000 employees in total. The textile industry can have declined by about $80-90 \%$ since the start of the millennium.

The two textile producers we met referred to a reduction in employment from 2,000 people to 200 and from 300 to 80 people respectively. Today's production is based on uniforms including school uniforms for private and public costumers.

Many different industries collapsed after the political changes from 1990s The reasons for this collapse are complex but a combination of not being competitive due to low skills, poor quality and changes in trade agreements.

Malawi exported a lot of textiles to South Africa under the SADU and MMT agreement until the year 2000 when some exporters were accused of importing Asian clothes into South Africa via Malawi and not exporting clothes produced in Malawi. This led to changes in the quotas for export to South Africa.

Again in 2000, the African Growth and Opportunity Act (AGOA) agreement on quotas to export clothing and appeal to the USA started up. This has been an important incentive to promote development in the industry. The agreement has been renewed several times but the terms have changed.

The larger context to this is that since 1 January 1995, international textiles and clothing trade has been going through fundamental change under the 10-year transitional programme of the WTO's Agreement on Textiles and Clothing (ATC). Before the Agreement took effect, a large portion of textiles and clothing exports from developing countries to the industrial countries was subject to quotas under a special regime outside normal GATT rules. Under the Agreement, WTO Members committed themselves to remove the quotas by 1 January 2005 by integrating the sector fully into GATT rules. ${ }^{18}$

The result for Malawi and other African countries after the quota system changed has been less export to USA. The competition from Asia has been difficult to meet in both price and volume.

\footnotetext{
${ }^{17}$ http://agoa.info/profiles/malawi.html

${ }^{18}$ https://www.wto.org/english/tratop_e/texti_e/texintro_e.htm\#(ATC)
} 
Cotton production in Malawi has also dropped and today cotton is mostly under Asian control and sold in Asia. The production was about 50,000 tons in 2007 (SemuBanda, 2007). Textile producers in Malawi now mainly import garment and fabric from India and China. In general there is a small market for new clothes mainly based on cheap import for china. There is a potential to develop a value chain in Malawi from cotton production, lint production, garment production and textile production, but the government has so far not been successful in developing supporting programmes for international investments.

In Malawi the second hand clothes market is not blamed as being a cause of the collapse of the textile industry, which in any case was main aimed at the export market. Second hand filled a gap in the market and has been an important solution in the situation with economic crises and poverty.

The textile industry in South Africa has been a much more important role in the total economy than in Malawi. The official statistics give a number of close to 200,000 employees in 2005 accounting for more than $4 \%$ of total manufacturing. By 2014 the number had declined significantly to about 110,000 workers (Statistics of South Afri$\mathrm{ca}$, 2014). The total value of the production has been about 40-50,000 mill Rand. In USD the value has fallen rapidly due to high inflation in South Africa. The industry is now mainly producing for domestic market.

Trade liberation and the fact that the industry has been unable to compete with the influx of cheaper clothing from Asia is the main explanation of the decline in the industry (Industri-all Global Union, 2015).

The import of new cheap clothes from China has increased significantly since 2004 (Vlok, 2006). This has been a direct result of removal of trade barriers following entry into to WTO in 1994. The competition with these cheap imports has been hard and the industry has not been prepared to meet this competition based on old production and low experience with international trade.

As in Malawi then it would seem that the threat to the industry has come from cheap imports of new clothing from Asia. The ban on imports of used textiles suitable for reuse has not prevented the decline in the industry since second hand was not the threat. 


\section{Protection}

\section{Malawi}

Worn clothing covered under tariff subheading 6309 are allocated a $25 \%$ import duty and $16.5 \%$ VAT. $^{19}$ The minimum valuation of used textile for calculating import duty for customs purposes is USD 0.90 per $\mathrm{kg}$. This is set in order to avoid under-pricing of goods for customs. There are lower rates for import from COMESA and SADC countries. New textile goods mainly follow the same $25 \%$ import duty.

There is no other import regulation in Malawi except that the items must have a fumigation certificate. This can easy be solved by using a patron with gas activated and put into container just before locking container for sealing before transport and custom.

There has not been any discussion to implement any import restrictions or ban on used textiles in Malawi and all the representatives from government and other stakeholders were clear that such a ban is not necessary.

The strict regulation in some neighbouring African countries results in traffic over the borders for buying and selling second hand clothes from Malawi. Interviewees are regularly approached by people from Zimbabwe, South Africa and other neighbouring countries interested in buying used clothes from Malawi.

\section{South Africa}

In South Africa there has been a ban on imports of second hand clothes, supposedly in order to protect the textile industry. The textile workers union has had a very strong voice in South Africa since the fall of apartheid, and there has been a strong influence on protecting the domestic market from both imports of cheap new clothes and second hand that have been viewed as a threat.

Under the interviews there was no clear statement about the reason for a ban on second hand, but business representatives told us that there was no benefits seen in importing second hand clothes. The problem with imports of second hand clothing seems to be mostly political and cultural; the idea of importing second hand clothes from white people in Europe goes against strong feelings of national and cultural pride.

Volunteer organisation could import second hand clothes and shoes as donation for poor people until 2004, after which a need for stricter control arose as a result of

\footnotetext{
${ }^{19}$ The Malawi Custom and Excise Tariff book.
} 
NGOs (church communities) organising resale second hand clothes in order to pay for their charity work.

There remains the possibility of importing winter coats for poor people, but there is a strict application system.

Rags are not banned but are restricted by quotas. The maximum quota reported by ITAC for import of rags to the recycling industry in South Africa is 4,600 tons/year. 63 companies have quotas for import and there are 40-45 recycling companies with demand for rags.

Illegal import was discussed under meetings in South Africa. The country has a strict control policy and people found guilty of illegal import face up to 10 years imprisonment and large fines.

There was no good explanation of the large registered import of second hand clothes, and existing sale of second hand clothes in markets was partly explained by the domestic collection of used textiles.

The Trade and Industry department in Pretoria told us that the ban on import on used textiles will remain. This is thought to be the result of political reasons with no clear goal apparent for protecting the textile industry.

\section{References}

Barré, J. (2014) Waste Market in Urban Malawi - A way out of poverty? Masters thesis, Dept. of Urban and Rural Development, Uppsala University http://stud.epsilon.slu.se/7550/

Danish Trade Union Council (2014) Malawi Labour Market Profile 2014 http://www.ulandssekretariatet.dk/sites/default/files/uploads/public/PDF/LMP/Imp_malawi_2 014_final_version.pdf

Industri-all Global Union (2015) Feature: A turnaround for South Africa's textile industry? Article published online.

Malawi National Office of Statistics (2013) Labour Force Study.

Semu-Banda, P. (2007) TRADE-MALAWI: Clothing and Textiles Become Unstitched. IPS News Agency Article from June 14, 2007. http://www.ipsnews.net/2007/06/trade-malawi-clothingand-textiles-become-unstitched/

Statistics of South Africa (2014) Manufacturing Industry. Statistical release $\mathrm{P}_{3002 .}$

Van Klaveren, M., Tijdens, K., Hughie-Williams, M., Ramos Martin, N. (2009) An Overview of Women's Work and Employment in Malawi. Decisions for Life MDG3 Project Country Report No. 6.

Vlok, E. (2006) The Textile and Clothing Industry in South Africa in: Herbert Jauch / Rudolf Traub-Merz (Eds.) The Future of the Textile and Clothing Industry in Sub-Saharan Africa. Bonn: Friedrich-Ebert-Stiftung, http://library.fes.de/pdf-files/iez/03796/16suedafrika.pdf 


\section{Appendix C: Poland country study}

\section{Reason for Selection and Study Methodology}

Poland was chosen as one of the study countries as it represents the largest receiver of used textiles directly exported from the Nordic region, and because all the textiles exported to Poland are wholly or relatively unsorted. It also has a large new textiles industry. The specific focus of the study in Poland was to find out what happens to the waste sorted from the original, to identify job creation in the used textile sector and identify whether the used textile imports have impacted negatively or positively on the national textile industry.

The study was carried out a three-day country visit supplemented by desktop study and discussions with Nordic-based experts. Import/export data of used and new textiles was extracted from the UN import/export database. Trends in output of the Polish textile industry were extracted from economic data held by Eurostat. Data and information on municipal waste treatment in Poland was gained from a number of sources including Eurostat, the OECD and the European Environment Agency.

Table 17: Interviewed/consulted experts are given in the table below

\begin{tabular}{llllll} 
Name & Position & Organisation & Type of organisation & Country \\
Fredrik Bratterud & Export Manager & Fretex International & $\begin{array}{l}\text { Exporter for Salvation Army in SE, NO } \\
\text { and DK }\end{array}$ & Norway \\
Dawid Wolpiansky & Export Manager & Trasborg & Used textile collection company & Denmark \\
Krzysztof Zareba & Section head & Ministry of Development & Government & Warsaw, Poland \\
Aleksandra Krysiak & Director & PIOT & Branch organisation for textile industry & Lodz, Poland \\
Arkadiusz-jazwinski & Owner & Naotex & Used textile sorter, distribu- & Warsaw, Poland \\
Joanna Szabunko & Researcher & Buy Responsibly Foundation & Consumer NGO & Krakow, Poland \\
Anonymous & & Customs Office & Government & Warsaw, Poland \\
Baktash Rahimi & Manager & Euroclot, & Used textiles wholesaler & Poznan, Poland \\
\hline
\end{tabular}




\section{Volumes and types of textiles imported}

According to the UN's import/export database the volume of imported worn clothing (code 6309) has been stable at around 70,000 tonnes per year, while the import of rags (6310) has increased from nearly zero in 2000 to nearly 80,000 tonnes by 2014 .

Figure 24: Imports of worn clothes and rags to Poland, 2000-2014

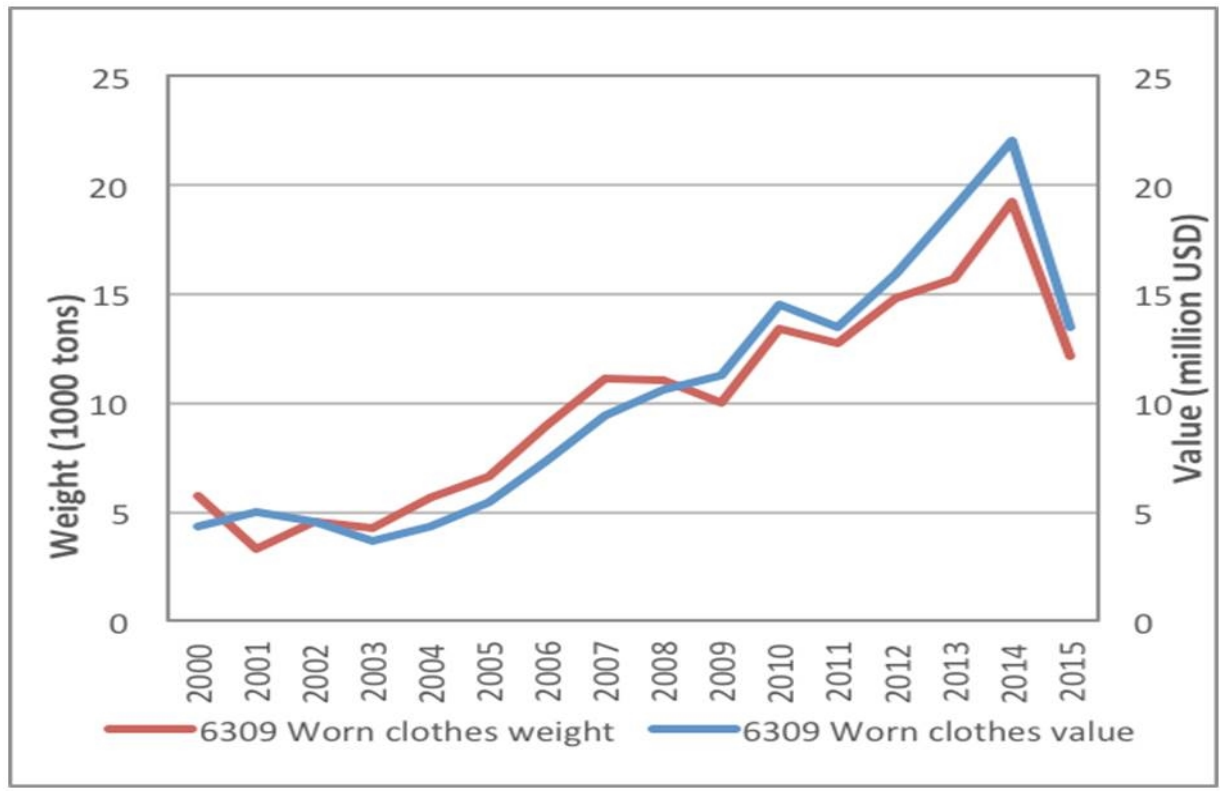

The total trade value of the imports increased from USD 25 million in 2000 to USD 135 million in 2014 at current prices.

$80 \%$ of all imported rags arrive from Germany. $8 \%$ is from the Netherlands. Of the Nordic countries only Denmark exports rags to Poland in any significant amount (650 tonnes), and this is very low compared to exports of worn clothing and textiles. 
Figure 25: Countries exporting over 100 tonnes of used textiles to Poland, 2014
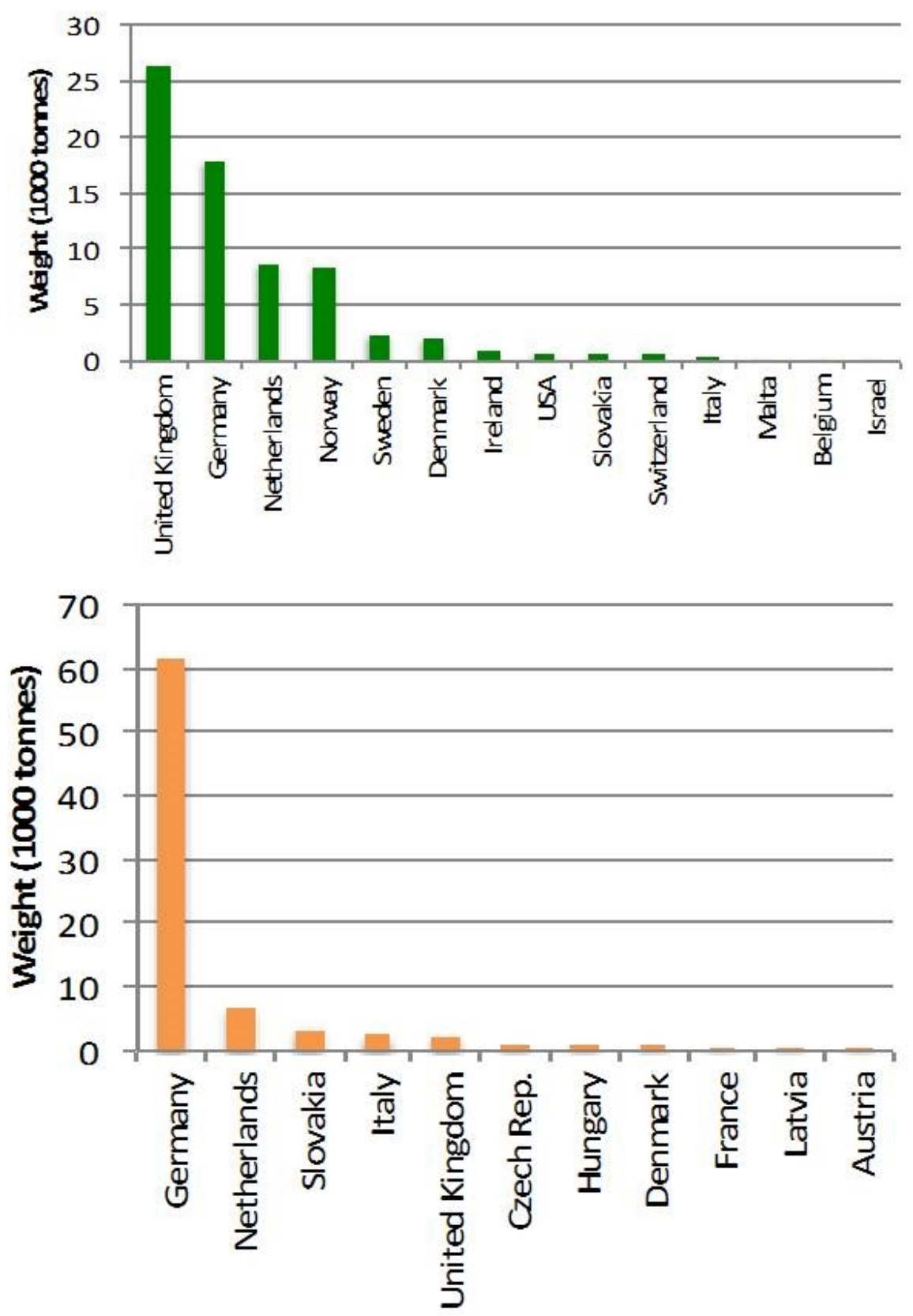

Note: 6309 Worn clothing (green) and 6310 Rags (orange). 
Nordic countries are on the other hand the most important exporters of worn clothing and textiles to Poland after the UK, Germany and the Netherlands, exporting nearly 13,000 tonnes in 2014, according to UN data.

As described in the Phase 1 report, it is not certain how well importers and customs offices distinguish between the two codes. The majority of textiles imported from Nordic countries for example are reported by Nordic collectors as being original i.e. containing both rags and textiles fit for reuse. According to interviewed sorting companies, this can be, and is, typically exported under code 6309 provided that the original undergoes some basic pre-sorting to remove larger pieces of non-textile waste.

However, until last year even textiles under code 6309 was considered as notifiable waste under Poland's interpretation of the EU Shipment of Waste Regulations i.e. orange code. However, importers and wholesalers report that customs carried out relatively few inspections of imported containers despite this coding. From 2015 used textiles are given a green code under the regulations.

Categorisation of used textiles is rather different in Germany which can cause problems for exports from the Nordic countries which pass through Germany to Poland, and also explains some of the trends we see in Figure 1. When Germany implemented the Basel Convention on Transboundary Shipments of Waste, textiles was included in Annex 7 as potentially hazardous waste thus subject to control. This means that notification papers need to follow shipments of used textiles and that drivers of textile shipments need to have certification as drivers of hazardous waste. Infringements can lead to combined fines of around 50,000 Euro for exporter and driver. One Danish exporter reports having paid such fines on at least one occasion. This may also explain why an increasing fraction of exports from Germany are classified as rags. This may also be largely original. This, however, is a theory that needs to be confirmed.

The collectors interviewed under Phase 1 , together reported having exported just under 17,600 tonnes of discarded textiles to Poland, all of which was original i.e. unsorted. This may, therefore, also contain non-textile waste and shoes. Six of the 13 collectors interviewed export original to Poland; Emmaus, UFF Sweden, Myrorna, Fretex, Frelsens Hær and Trasborg. From 2015 all exports by Myrorna, Fretex and Frelsens Hær, national divisions of the Salvation Army are centrally coordinated by Fretex International. Together these represent $84 \%$ of all textiles imported from the interviewed collectors.

All imported textiles from the Nordic countries are processed in (mostly) privately owned sorting plants. Some textiles are re-exported again from Poland after sorting while others remain in the country (see below). 


\section{Overview of process routes for textiles}

Overall figures for process routes for all textiles imported to Poland are not available. We received data, however, via interviews with two sorting companies that sort textiles purchased from Fretex International under a Code of Conduct.

\begin{tabular}{|c|c|c|c|c|c|}
\hline \multirow[b]{2}{*}{ Company } & \multicolumn{2}{|r|}{ Reuse } & \multicolumn{2}{|c|}{ Recycling } & \multirow{2}{*}{$\begin{array}{l}\text { Other } \\
\text { Waste }\end{array}$} \\
\hline & Reuse in PL & Export for reuse & Recycled in PL & Export for recycling & \\
\hline 1 & $20 \%$ & $\begin{array}{l}50 \%(35 \% \text { Africa; } 15 \% \\
\text { Pakistan) }\end{array}$ & $10 \%$ (wipers) & $8 \%$ & $\begin{array}{l}12 \% \text { (10\% textile, } \\
2 \% \text { non-textile) }\end{array}$ \\
\hline 2 & - & $\begin{array}{l}75 \% \text { (10\% Eastern Europe; } \\
55 \% \text { Africa/Middle east; } \\
10 \% \text { Pakistan) }\end{array}$ & - & $\begin{array}{l}15 \% \text { (10\% Tuni- } \\
\text { sia/Belarus; } 5 \% \text { In- } \\
\text { dia/Pakistan) }\end{array}$ & $\begin{array}{l}10 \% \text { ( } 7 \% \text { textile, } \\
3 \% \text { non-textile) }\end{array}$ \\
\hline
\end{tabular}

Due to narrowing margins, value needs to be obtained from every single fraction of the imports of original, as far as is possible. Those importers that survived are adept at finding markets for all their fractions and adjusting these as the market changes.

Most of the value is obtained via the cream - the top $10 \%$ of the imports, and the remainder on tropical mix and second grade being sold in Africa and the Middle East. All the lower quality fractions are being sold at low prices. However, this is preferable economically to disposal via normal waste routes which cost the importer money.

To illustrate this importers are buying original from between $75-85$ Eurocents $/ \mathrm{kg}$ depending on country of origin and the size of importer. Following sorting, the $10 \%$ cream is sold in Poland or to Eastern Europe for typically EUR 4-5/kg while A and B grade exports to Africa and the Middle East are selling for around 80 Eurocents $/ \mathrm{kg}$.

Lower quality, worn clothing is sold to Pakistan for just $10 €$ cents i.e. $2 \%$ of the price of the cream. Industrial wipes are sold for around 40 Eurocents $/ \mathrm{kg}$ cut and ready for use or 10-15 Eurocents uncut. Separated plastic and paper is sold for 4-5 Eurocents. With low prices for the low grade fractions the sorters are making a loss since bailing on its own costs the importer 3 Eurocents $/ \mathrm{kg}$. But, these routes are still overall, preferable to disposal to waste companies which costs the importer roughly 5 Eurocents per $\mathrm{kg}$.

The following sub-sections provide a brief overview of the specific routes observed for textiles imported to Poland. 


\section{Reuse}

\section{Domestic reuse}

15-20 years ago, the majority of reusable textiles imported to Poland were reused domestically. The Polish economy had shrunk to around half its size during the first half of the 1990s. Second-hand shops became the key source of clothing for a large part of the population who couldn't afford new. The second-hand sector thus provided an important service during that period. The younger generation, demand for secondhand also arose from a growing status associated with wearing western clothing brands (Wolpiansky, D. pers. comm.).

The demand has continued to be high but in recent years as the economy has improved and the middle class grown, the demand has shifted to a higher quality, the socalled cream. Clothing imported from the US, the UK and the Nordic countries (because of higher quality) is strong while demand for clothing imported from Germany has reduced. At the beginning of the 2000 s approximately $90 \%$ of the reusable textiles imported by wholesalers was resold in the Polish second-hand market. More recently, the figure has dropped to around $50 \%$ with the remainder being exported for reuse elsewhere (Wolpiansky, pers. comm.; Jazwinski pers. comm.).

Some sorters/wholesalers have a chain of their own second-hand shops, since keeping it internal allows them to also export clothing which is returned unsold from the shops. Others sell on to domestic retailers.

In Poland, as in the Baltic states and Eastern Europe, it is typical for shops to have a sales policy where newly arrived clothing is labelled with a higher price, with prices being reduced as the week moves forward (Wolpiansky, pers comm). Shops are busiest on the first day when the fresh clothing arrives. Textiles that aren't sold by the end of the week are returned to the wholesaler for export elsewhere. This policy ensures a higher sales rate in the country and that the most value is obtained from the clothing.

Prices for 2 nd hand vary significantly dependent on quality and location. NaoTex has 11 shops. Those in the suburbs tend to sell per $\mathrm{kg}$, whereas the shops closer to the city centre sell per piece. Average sales prices are around EUR 4-5 per kg but can vary dramatically depending on brand and quality. Price differences between used and equivalent new are greatest for high quality brands at perhaps one fifth to one tenth of the price. For non-brand 2 nd hand is typically half the price. 


\section{Export for reuse}

Some sorters also export cream for reuse in other countries, typically Eastern Europe including Russia. Prices are perhaps slightly lower than in Poland. The decision on whether to export depends often on connections. The second sorter interviewed in Poland for example exports to a company in Ukraine to which it has family connections.

The next quality down from the cream has earlier been sold in Poland but is now entirely exported elsewhere due to a more wealthy domestic market. Most of the exports of African Grade A and B are to Africa and the Middle East. A typical price for these is 80 Eurocents per $\mathrm{kg}$. Winter clothing typically costs 50 Eurocents. For a typical description of its fate there see the Malawi report.

Lower grade clothing with colour fading, loose stitching or stains is typically sold as Pakistan grade to Asia. Here it will be sold (with or without repairs) for reuse where possible, or failing that sold for the domestic recycling market (see Appendix D). Typical sales price is around 10 Eurocents. The price has decreased by $80 \%$ in the last decade and Pakistan buyers are becoming more picky. This is the result of an excess in supply as more and more (lower quality) textiles are collected in wealthy countries looking for a market abroad. Nevertheless it is still possible for example to sell pairs of non-matching shoes or single shoes on the Pakistan market.

\section{Textile recycling}

The three options for recycling encountered during interviews were 1) industrial wipes 2) worn out jeans for mechanical recovery of cotton yarn and 3) woollen and acrylic sweaters for unravelling.

Industrial wipes are either cut and sold ready for use or are sold at a lower price to other companies for cutting. Cutting typically costs 20 cents $/ \mathrm{kg}$ in labour and energy. Cut wipes are sold for around 40 cents while uncut are sold for around 10-15 cents with variation depending on quality. Three types of wipes are sold, white/light pure cotton for wiping of machinery, coloured cotton and fibre blends which are used for more general wiping and soaking up of spills in factories and plants etc. These replace new fibre reusable or single use cellulose wipes.

Of the two importers interviewed, one cut and prepared wipes in their own plant and sold for domestic use in Polish industry, while the other sold uncut to plants in Tunisia and Belarus. There are also companies in Poland that specialise in cutting industrial wipes from used textiles provided by others.

One of the importers interviewed exports sweaters to India for unravelling of yarn for use in new sweaters or blankets and jeans to also to India for mechanical recovery 
of cotton for use in a range of products, potentially also new woven products. The price of both is around 10 cents per $\mathrm{kg}$.

\section{Waste}

Imported original typically includes both non-textile and textile waste. As describe earlier, due to the low margins available money is squeezed from every part of the original as far as possible, however low the quality. This is also true of the waste - for which they have to pay if treated as mixed waste. Thus this is sorted into usable fractions as far as possible.

The two sorters visited sorted out non-textile bric-a-brac like kitchenware and toys for resale either in Poland or for export to Eastern Europe. Plastic bags and paper/cardboard is also separated and sold for recycling for approx. 3-4 cents $/ \mathrm{kg}$. Hard plastic is also typically separated and sold for recycling for around 6 cents.

Non-reusable or recyclable textile waste typically comprises wet or mouldy textiles, although one of the sorters visited has large industrial tumble driers for drying better quality textiles that have got wet during the collection process.

One of the sorters visited gives his waste textiles to a cement factory for incineration where it presumably replaced fossil fuels. This comprises about $10 \%$ of the total he receives and he pays 5 cents $/ \mathrm{kg}$ for this disposal route that is slightly cheaper than other mixed waste collection by private companies/municipality. He also reported that he occasionally has also sent Pakistan grade to the cement furnace, if he can't get a price that can pay for the labour and materials involved in bailing this. This is rare though.

The other sorter has his non-recyclable textiles and non-textile waste following removal of plastic and paper/cardboard, collected by a private waste company. This comprises $5-8 \%$ of the total original and costs 5 cents $/ \mathrm{kg}$ for the collection. Importantly this waste is kept separate from kitchen and staff waste. It is therefore dry and the waste company sorts it further in their plant to retrieve additional recyclable elements as far as possible.

Due to the economic conditions under which sorters operate we presume that this treatment of waste is quite typical for Polish sorters i.e. that they extract the plastic and paper/cardboard for sale to recyclers and the rest is collected in a dry state (without any wet organic waste) to waste companies.

Since revised waste legislation was adopted in 2012, the municipalities determine which waste treatment facility private waste companies must use (Fischer and Koziel, 2014). Treatment of mixed waste varies by region, but possibilities are landfill, MBT 
with some material recovered for recycling and the remainder landfilled, and, to a low (but increasing degree) incineration with energy recovery (Fischer, 2013).

In 2012, landfill still dominated municipal waste treatment, despite rapid increases in rates of recycling, with $75 \%$ of total municipal waste being disposed of in landfills (OECD, 2015). However, dry waste is more likely to be sorted in MBT or other types of facilities to obtain recyclables. Since the waste from sorting plants is dry, recovery rates may be higher than the average $25 \%$.

The share of incineration of municipal waste will also have increased since the last data year as four large incinerators with energy recovery were commissioned since end 2014 giving five in total. ${ }^{20}$ There isn't yet data on the share of municipal waste which is being sent to incineration since these incinerators were commissioned. We therefore, assume that the mixed waste from sorting plants has the same fate as average municipal waste in Poland in the most recent data year, 2012 (see Figure $C_{3}$ ).

\section{Figure 26: Municipal waste treatment in Poland 2000-12}

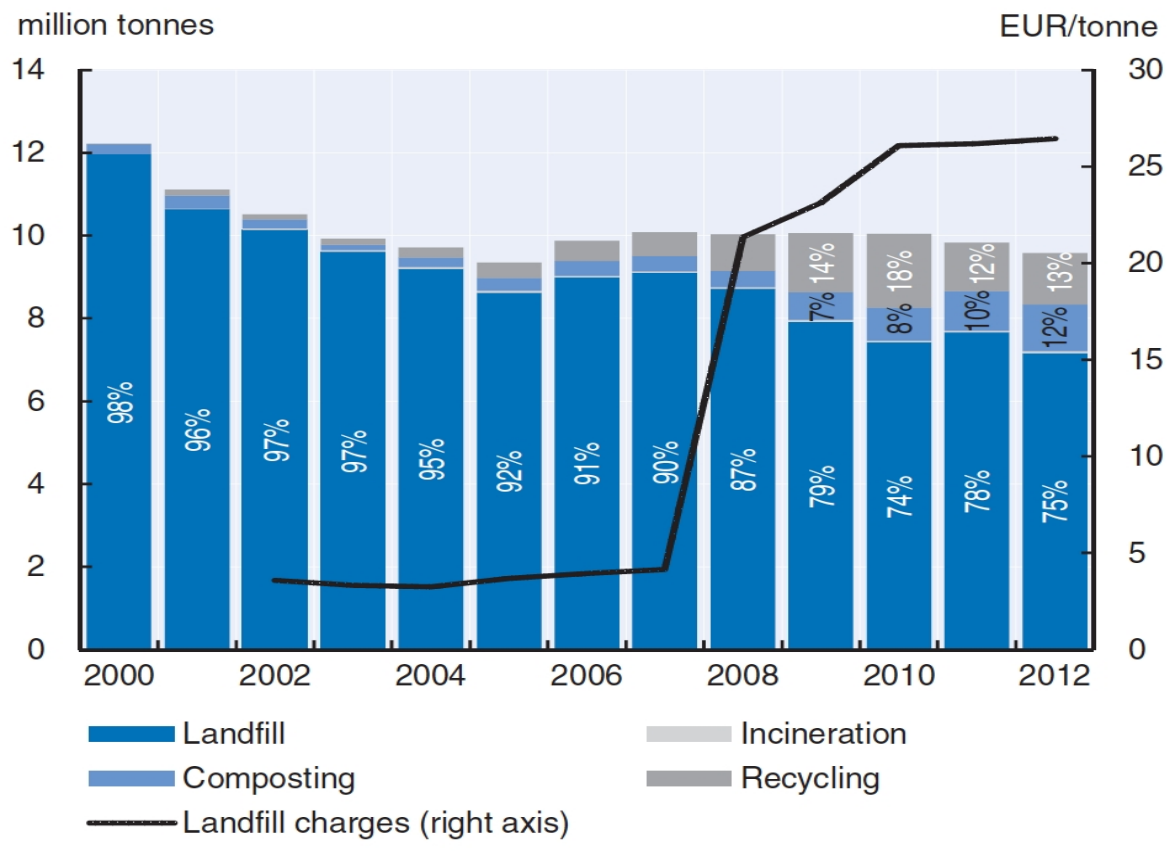

Source: OECD, 2015 .

\footnotetext{
${ }^{20}$ http://mostostal.waw.pl/company/news/archive/ecogenerator-na-viii-konferencji-o-termicznym-przeksztalcanieodpadow-komunalnych-tpok-2016-7c6739fa
} 
By 2012, all municipally approved landfill sites in Poland met EU standards given in the Landfill Directive (Fischer, 2013).

\section{Employment and working conditions}

\section{Employment in the used textile sector}

None of the people interviewed had a clear overview of the numbers of companies or numbers of people working in the used textile sector. The sector is dominated by Vive Textile Recycling which processes 330 tonnes a day and employs over 1,000 people. ${ }^{21}$ Vive processes around a third of all the used textiles imported to Poland. There are one or two other large actors processing more than 50 tonnes a day and a larger number of medium-sized companies processing 10-30 tonnes a day.

The overall numbers of companies have fallen significantly over the last 15 years as the margins got narrower and only the more efficient companies were able to survive. Certainly the Chamber of Commerce for the sector which used to have over 100 members now only has around 20 (Jazwinski, pers. comm.).

A very rough estimate of total numbers of employees can be gained by developing a figure for the number of full-time employees per tonne of processed original and multiplying by total imports.

One of the interviewed companies is involved in the value chain of imported original all the way to final sales of the highest quality used textiles to Polish consumers, and of sales of cut industrial wipes to Polish industry. Thus it encompasses the full valve chain that exists within Poland since second grade textiles for reuse are universally exported from the country for resale elsewhere (see earlier).

The company processes approx. 1,200 tonnes a year of imported original, and has 28 full time workers; 15 in the sorting plant and another 13 in the 2nd hand retail shops. The other company interviewed receives 3,600 tonnes a year and employs 50 people in the sorting plant. Thus we can assume approximately 1.4 employees in sorting plants per 100 tonnes received and another 1.1 employees in Polish retail downstream.

Approximately 90,000 tonnes of worn clothing and 90,000 tonnes of rags are imported to Poland (see Figure 1). However, we suspect that the rags is also original but are defined as such due to Germany's stricter waste classifications.

\footnotetext{
${ }^{21}$ http://www.client.mobeedick.com/vive_dev/vive-textile-recycling/en/
} 
Assuming 180,000 tonnes of original imported to the country this suggests employment of approximately 2,300 people working in sorting plants and perhaps another 2,000 working in 2nd hand retail, connected to the imports of used textiles. This number fits well with employment reported by Vive Textile Recycling which also runs retail shops via its sister company Vive Profit Centre.

Looking at the 17,600 tonnes imported from the Nordic region, this might lead to the employment of around 400 people in total in Poland.

Further employment will be generated in the countries which receive re-exported sorted textiles but this is considered in the other country reports.

\section{Working conditions}

No general overview could be obtained of conditions for workers in the used textile industry. Those sorters/wholesalers who were visited have contracts with Fretex International and/or Emmaus Björke and are thus expected to meet the standards for workers conditions and rights set by both these charities. This is described in more detail below.

This has a wider effect since these companies are also processing textiles received from other sources. The CoC's apply to operations as a whole and not only treatment of an individual collector's textiles.

Conditions for workers in the used textile sector not specifically covered by CoC's are less clear. If conditions are similar to the wider textile industry in the country, then workers are likely to suffer from low wages and lack of union representation, although conditions have improved significantly over the last 15 years.

Figure 27: Wages in the garment industry compared to the minimum wage and the national average

Minimum wage (net wage; 1.1.2015)

Average net wage

interviewed workers (including overtime and bonuses - 2015)

garment industry (2013)

industry (2014)

whole economy (2014)

Subsistence (socioeconomic) minimum per month, family of four (2014)

\section{$1.286,16$ PLN $\quad 312$ EUR}

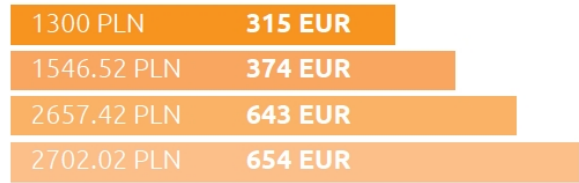

\subsection{9,35 PLN $\mathbf{8 2 5 . 4 8 ~ E U R ~}$}

Source: Fairwear Foundation, 2015. 
A 2005 Clean Clothing Campaign investigation of conditions in the Polish textile industry found that conditions for women were often breaching work standards specified by the ILO pressured by high unemployment rates and passivity of unions. Forced overtime was typical under threat of loosing bonuses or even dismissal. Safety was also compromised by older and unsafe equipment (Clean Clothing Campaign, 2005).

By the time the Fairwear Foundation carried out a similar study in 2010-12 conditions had improved. In particular, excessive overtime was much less evident as were compromises with health and safety (Fairwear Foundation, 2012).

However, wages remain low due to lack of union activity, and the low level of the national minimum wage. Union representation is particularly difficult due to the very large number of small companies in the industry. Over the past 20 years the level of unionization dropped from about $80 \%$ of workers to about $14 \%$.

Surveys in 2015 found that the average wages in the garment industry lies above the minimum wage, but are only $60 \%$ of the national average wage for industrial workers (see Figure $\mathrm{C}_{4}$ ). According to the textile branch organisation (PIOT) wages are higher for non-garment textiles workers due to greater technical demands, lying at around 2,000 PLN per month, though this is still only $75 \%$ of average wages for industrial workers. Moreover, some external observers consider the national minimum wage not to be a living wage, especially for families with children. Thus many workers choose to work without a contract for which they can receive a higher wage but loose their social security (Fairwear Foundation, 2015). PIOT also reported that wages for women are typically $20 \%$ lower than for men for the same job (Kryziak, pers. comm.).

It is hard to say how wages in the used textile sector compare to these. Certainly sorting of textiles into the many different quality and product types is skilled work which requires six months of training. Thus, experienced sorters are a resource that companies cannot afford to lose and pay higher wages to accordingly. Moreover, sorters are almost exclusively women, as it is a widespread belief in the branch that a typical man cannot be trained to do this work. Men are more confined to the heavier loading, unloading, bailing work etc., which requires lower skills and therefore may not be paid much above the minimum wage without union representation.

Wages under the minimum wage are less likely since the interviewed sorting companies reported that the Polish authorities regularly check working conditions. These checks are of course more likely for larger companies, which are fully registered. The interviewed companies said that ten years ago there were a number of "grey" actors operating under the radar of the authorities. These have largely disappeared, in part due to tighter controls but mainly because conditions are such that only well-established and well functioning companies can survive. 
Fairwear Foundation's survey found large differences in conditions for workers depending on which western brand they are producing clothing for. The Foundation thus urges western brands producing in the country to adopt codes of conduct to ensure reasonable conditions for workers in the garment industry (Fairwear Foundation, 2015).

\section{Codes of conduct and social programmes}

The interviewees had experienced an increase in the number of organisations that they buy from who make demands on the buyer and in some cases operate a code of conduct complete with third party audits. Only charities so far seem to make these kinds of demands. National branches of the Salvation Army and the Red Cross are amongst those that do have codes of conduct, along with UFF/Humana who have a similar rule set but mostly use their own sorting facilities elsewhere in eastern Europe.

As noted earlier, Fretex International is responsible for coordinating all exports by Myrorna, Fretex and Frelsens Hær, national divisions of the Salvation Army. these represent $84 \%$ of all textiles imported from the Nordic collectors interviewed under Phase 1 of this project.

Fretex International runs a Code of Conduct for buyers which is similar to a standard CoC used by all Salvation Army national organisations in Europe. It focuses on working conditions for the companies staff, including fair wages, not excessive working hours, lack of discrimination, zero child labour and implementation of health and safety guidelines. It also includes environmental considerations by requiring that companies maximise reuse and recycling as far as possible and minimise waste, and reduce the environmental impacts of transport as far as possible.

The $\mathrm{CoC}$ is monitored and enforced by internal annual audits and externally verified by third part auditors which visit each company roughly every three years. Rather than operating a fail and out system, Fretex International's approach is to assist buyers by drawing up plans for improvement such that they can meet $\mathrm{CoC}$ requirements at a given point in time in the future.

As described earlier, in Poland at least, the current economic conditions ensure that companies are in any case forced to squeeze every cent from the imported textiles by selling all items which possibly can be reused, and recycling as far as possible everything else. However, examples were found where companies aren't separately collecting hazardous waste such as batteries and paint that might find their way into original, and audits attempt to correct this.

Working conditions and health and safety are potential forced in the wrong direction by narrow economic margins. Here, however, companies reported that the Polish 
regulators are very strict with respect to regulating working conditions, wages and fire regulations. One company that was visited had had two health \& safety control audits and three labour control audits by regulatory government departments since 2013 . Nevertheless, Fretex International has found some slippage with respect to use of safety clothing and partial blockage of fire-fighting equipment which is now being acted upon.

Moreover, the wish to keep hold of trained staff also encourages them to adopt fair wage policies and decent working conditions.

Therefore, in general the companies said that they did not see charities' CoCs as a burden but rather as a help to them in improving their systems. Moreover, and very importantly, the companies stated that the openness and above-board nature of their contracts with charities more than offsets any inconvenience the CoCs might bring. This is a sector where honesty and trust is of extreme importance. The highest quality $10 \%$ of the original, brings half of the income to the sorting company. Therefore if the seller tampers with the original before exporting it and skims off just a few good items this can completely undermine the buyer's economy.

None of the Nordic organisations exporting to Poland have specific social programmes in the countries which are connected to the trade in textiles.

\section{Textile industry}

In 2014, Poland had 17,000 firms in the textile and clothing industries employ some 150,000 people, making Poland the EU's eighth largest market in terms of sales. ${ }^{22}$ Clothing represents 12,800 companies and 103,000 employees, and other textiles 4,400 companies and 49,000 employees. However, clothing provides EUR 1.7 billion GVA, while other textiles bring EUR 2.4 billion of GVA. In 2014 investment in the branch was $94 \%$ higher than in $2013 .{ }^{23}$ The textile industry is one of the ministry's 15 priority sectors for export promotion. ${ }^{24}$

Poland is a country with a long history of garment production. Since the late 1990 s the garment industry has mainly been operating as the factory of the west as part of the so-called outward processing trade (OPT) where western brands outsource there production to the country (Zareba pers. comm.).

\footnotetext{
${ }^{22}$ http://www.thenews.pl/1/12/Artykul/197768,Poland-to-promote-textile-fashion-exports-EconMin-says

${ }^{23}$ 03. PIOT -A.Krysiak PIOT Cracow 27.04.ppt

${ }^{24}$ http://www.thenews.pl/1/12/Artykul/197768,Poland-to-promote-textile-fashion-exports-EconMin-

says\#sthash.dCuyLpEP.dpuf
} 
Over the past few years, this activity has been reducing and the branch has been shrinking in both levels of employment and output (see Figure $C_{3}$ ). The cause has been the higher costs of production in Poland compared to other countries, especially Asia. At the same time, the proximity to European clients as well as a highly skilled workforce represent comparable advantages (Fairwear Fashion, 2012). The traditional garment industry is transforming into a fashion industry with an increasing number of Polish companies shifting their production outside Poland, leaving their design and trade departments behind. However, OPT activities still exist. 50\% of garments produced in Poland are exported (Fairwear, 2012).

The Polish textile industry and government have previously viewed the used textile sector in a negative light as posing a threat to the domestic industry. This view was predominant in the late 1990 s and early 2000s. As already described earlier (under Reuse) during this period, there was significant poverty in the population and some segments could only afford either cheap low quality imports from Asia or 2nd hand from western Europe. These were both priced considerably lower than domestically produced garments (some report as little as a tenth of the price, Zareba pers. comm.). These challenged the domestic market, though it could also be argued that they provided the poor with clothing that they otherwise would not have access to. Moreover, both government officials and the textile branch itself agree that the main threat was from cheap Asian imports.

Since around 2007 the 2 nd hand sector is no longer considered a threat. This is a result of demographic and economic development rather than via government action. Poverty is no longer widespread and the growing middle class can afford new clothing, also that produced domestically. Although the 2 nd hand retail sector still has a market a significant share of this has shifted abroad (Wolpiansky pers. comm.; Zareba, pers. comm.).

The Polish government is investing EUR 95 million to fund research and development activities under the Innotextile Programme between 2014-2020. ${ }^{25}$ However, this money is primarily aimed at innovative textiles such as hydrotextiles, geotextiles and agritextiles, and not clothing and household textiles as are covered by this NCM project.

The government has done little to react to the threat it felt the 2nd hand sector imposed during the first part of the millennia. This in part because it was forced due to its wish to be included in the EU to have open borders to trade (see below).

${ }^{25} \mathrm{http}: / /$ www.innovationintextiles.com/poland-to-invest-95m-to-spur-innovation-in-lodz-textileindustry/\#sthash.glDTxe2N.dpuf 
Figure 28: Output and employment in the Polish textile industry, 2000-2012

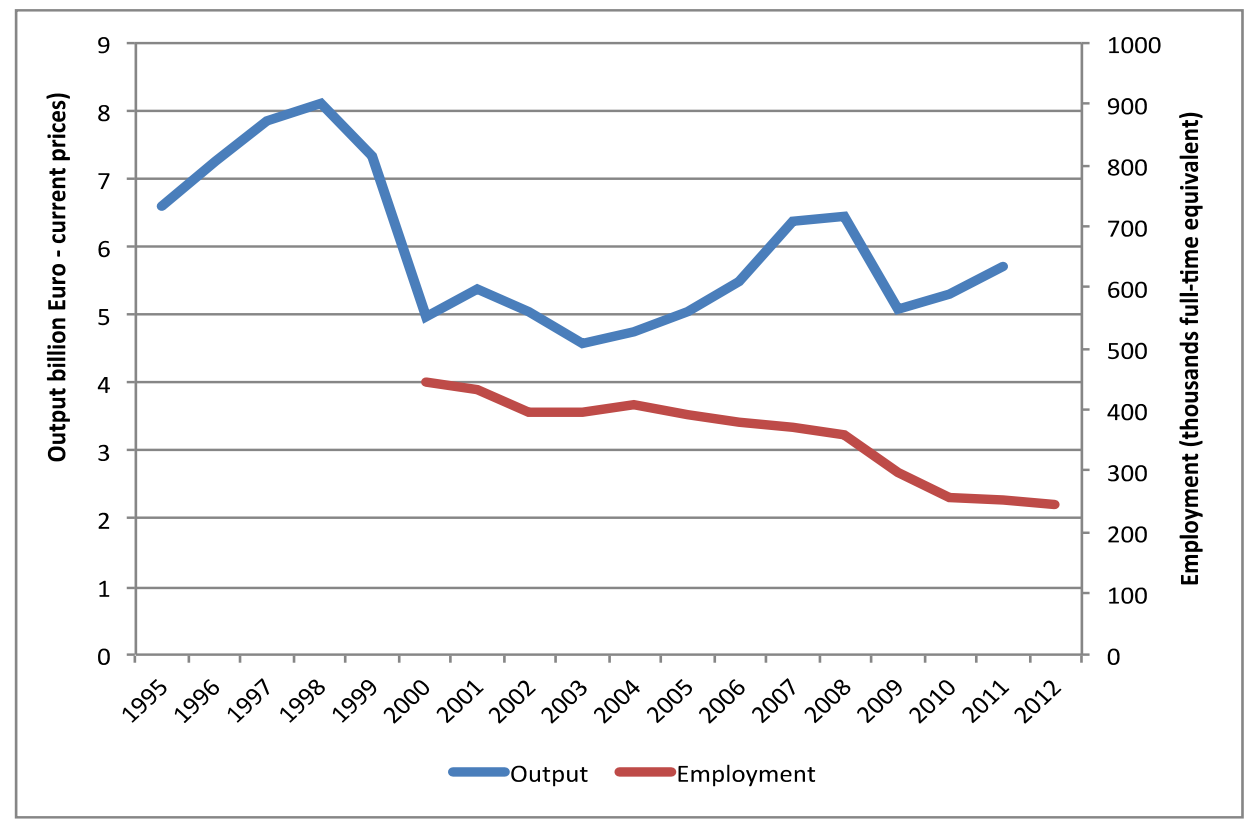

Source: Eurostat.

\section{Protection}

There are no specific restrictions on the import of used textiles in Poland. If there is non-textile waste included in imports of "original" this will fall under the EU Shipment of Waste Regulations 2014. ${ }^{26}$

Importers of textiles from outside the EU and EFTA regions need to pay Polish VAT on the value of the imports which lies at $23 \%$. They also need to pay import tax. Interestingly, tax on imports of used textiles (5.3\%) is lower than import tax on new textiles (12\%). However, almost all used textiles imported to Poland arrive via other EU countries and thus are not subject to import duties.

In the late 1990s, under agreement with the EU the Polish government set high import taxes on imports of new clothing from Asia to try to reduce the competition for the local textile industry. However, in 2001 China entered the WTO which led to con-

\footnotetext{
${ }^{26}$ http://ec.europa.eu/environment/waste/shipments/legis.htm
} 
cessions on Polish import taxes and the special tax was completely removed in 2005 (Kryziak pers. comm.).

Since then the Polish industry has not received external assistance in the competition with cheap imports and has responded by transforming the industry into specialised technical textiles and the development of brands for the home market and in a few cases the rest of Europe (see earlier).

\section{References}

Clean Clothing Campaign (2005) Work conditions of women working in cloth factories in Poland.

Fairwear Foundation (2012) Country Study Poland, 2010-2012 http://www.fairwear.org/ul/cms/fckuploaded/documents/countrystudies/othercountries/poland/countrystudypoland.pdf

Fischer, C. (2013) Muncipal Waste Management in Poland. European Topic Centre for SCP report for the European Environment Agency.

Fischer, C. and Koziel, L. (2014) Regional Municipal Solid Waste Management in the Warmi ńsko-Mazurskie region. ETC SCP Working Paper No 32014.

Aleksandra Krysiak pers. comm. (2016) Interview with Director of Polish textile industry branch association PIOT, Lødz, 16th June 2016.

OECD (2015) Environmental Performance Review, Poland 2015. http://www.oecd.org/poland/oecd-environmental-performance-reviews-poland-20159789264227385-en.htm

Arkadiusz Jazwinski pers. comm. (2016) Interview with owner of Naotex, Poland, 15th June 2016.

Dawid Wolpiansky pers. comm. (2016) Interview with officer in Trasborg, Høj Taastrup, Denmark, 1oth June 2016.

Krzysztof Zareba pers. comm. (2016) Interview with Ministry of Development officer, Warsaw, Poland, 14th June 2016. 



\section{Appendix D: Pakistan country study}

\section{Reasons for Selection and Study Methodology}

Pakistan is located in South Asia neighbouring India, Iran, Afghanistan and China. It is the $36^{\text {th }}$ largest country in the world measured in $\mathrm{km}^{2}$ and consists of four provinces and four federal territories.

The analysis carried out under Phase 1 identified Pakistan as the largest non-EU importer (direct and indirect) of used textiles from the Nordic countries making Pakistan a relevant country to focus on. However, imports from the Nordics are only a small part of the total.

It is often the lowest quality of reusable textiles that are sent to Pakistan. As such the country lies at the end of the quality cascade for Nordic textiles. It is therefore of interest to see how textiles are handled and whether textile waste is generated. At the same time Fretex International also exports pre-sorted textiles to sorting companies in special economic zones in Pakistan for sorting and subsequent re-export. Thus two different types of textile handling take place in the country, both of which are of interest.

Due to security risks for western visitors, site visits have not been possible. Therefore, the country study has had to rely upon interviews with Nordic exporters and phone/e-mail correspondence with Pakistan government officials and with companies located in Pakistan.

Table 19: Organisations consulted in Pakistan

$\begin{array}{llll}\text { Organisation } & \text { Type of org } & \text { Contact person } & \text { Position } \\ \text { Ministry of Textile } & \text { Public } & \text { Syed Abbas Mehdi Kanwar Usman } & \begin{array}{l}\text { Manager, Research Director in } \\ \text { R\&D Advisory }\end{array} \\ \text { Ministry of Commerce } & \text { Public } & \text { Various } & \\ \text { Federal Board of Review } & \text { Public } & \text { Various } & \\ \text { Danish Enterprises } & \text { Local importer } & \text { ABID IQBAL } & \text { Director } \\ \text { Danish Embassy to Pakistan } & \text { Public } & \text { Misbah Zafar } & \text { Commercial Officer } \\ \text { Fretex International } & \text { Charity organisation } & \text { Fredrik Bratterud } & \text { Export Manager }\end{array}$


We have carried out interviews with Fretex International, the largest Nordic exporter to Pakistan, the Pakistan Ministry of Textiles, the Danish Embassy in Pakistan and Danish Enterprises, a local company importing textiles from the Nordics. The Danish Embassy in Karachi was also engaged to carry out some local studies.

We sought to confirm and supplement the information received from those sources through data from the UN databank, International Labour Organisation (ILO), the World Bank and via reports that we could find through desktop research.

The analyses only focus on the import of second hand textiles and not on the overall textile production in Pakistan.

\section{Volumes and types of textiles imported}

The analyses of the amount of textiles imported in Pakistan are mainly based on data from the UN-import export database. ${ }^{27}$ We have used the data reported by Pakistan to the UN on imports to the country as these are expected to be more accurate.

Used textiles imports are divided into two groups, 6309 - worn clothing and textiles suitable for reuse - and 6310 - rags. Information on the state and quality of the textiles is not provided in the UN database. Our interviews and data from UN indicate that the majority of imports consist of worn clothing and other worn articles while only a small part of the imports are rags.

The results are illustrated in figures 1 and 2 . The numbers show the imports of worn clothing and textiles and of rags from all countries. In 2015 the value of total imports reached USD 209 million. As seen from figure 10, the imports of rags experienced a drop between 2007 and 2008 . This could be explained by the global financial crisis. The same drop is not reflected for worn clothing, which increased in both weight and value in almost all years.

\footnotetext{
${ }^{27}$ http://comtrade.un.org/data/
} 
Figure 29: Imports of worn clothes to Pakistan, 2004-2015

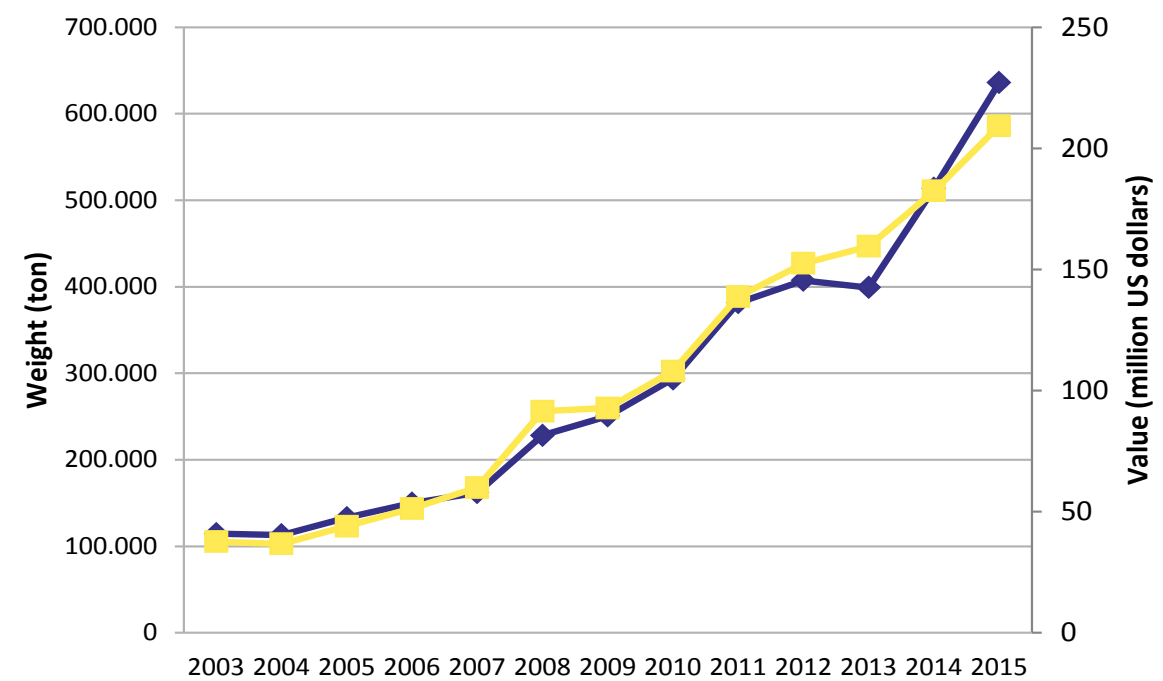

$\underset{\sim}{\sim} 6309$ Worn Textiles weight $\quad-\quad-6309$ Worn Textiles value

Source: UN-database and own calculations.

Figure 30: Imports of rags to Pakistan, 2004-2015

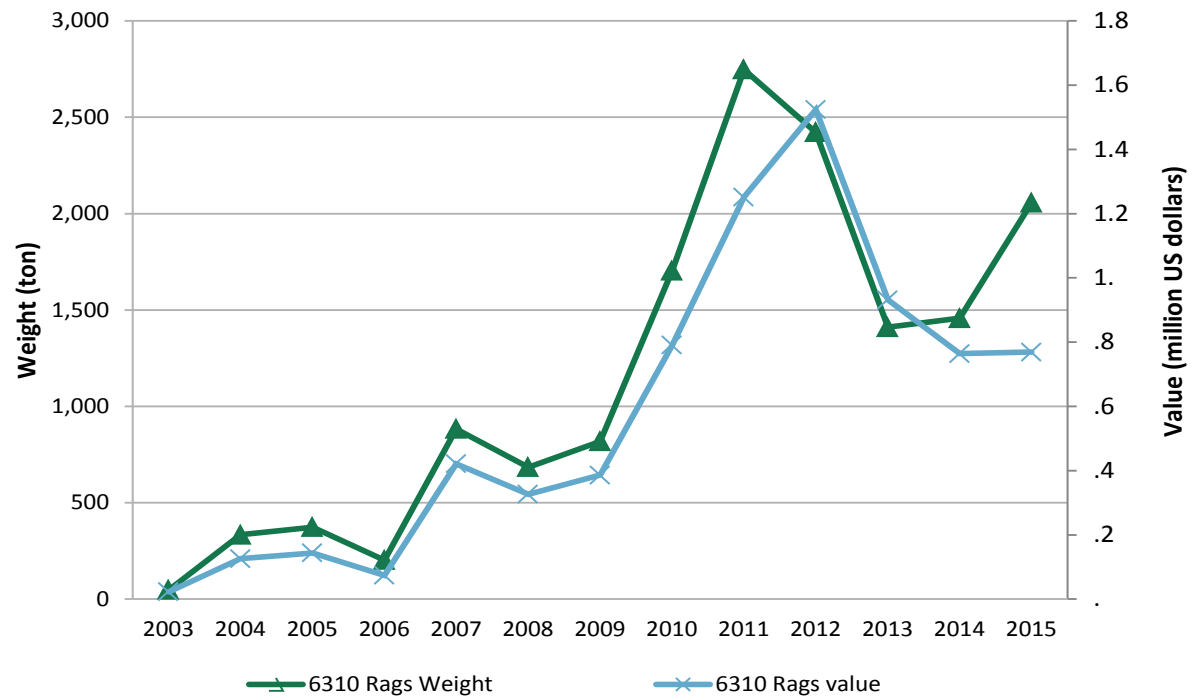

Source: UN-database and own calculations. 
Table 20: Textile exports to Pakistan from Nordic countries $(\mathrm{kg})$

\begin{tabular}{|c|c|c|c|c|c|}
\hline Year & Denmark & Finland & Norway & Sweden & Grand Total \\
\hline 2004 & 16,103 & & 179,882 & 44,000 & 239,985 \\
\hline 2005 & 38,825 & & 629,840 & 10,000 & 678,665 \\
\hline 2006 & 20,500 & & 587,365 & 32,000 & 639,865 \\
\hline 2007 & 1,200 & & 81 & 34,000 & 35,281 \\
\hline 2008 & & & 15,000 & 51,000 & 66,000 \\
\hline 2009 & & 348 & 45,000 & 150,000 & 195,348 \\
\hline 2010 & 14,875 & 13,038 & 345,406 & 749,000 & $1,122,319$ \\
\hline 2011 & & & 507,851 & 700,585 & $1,208,436$ \\
\hline 2012 & 50,000 & 80 & 729,698 & $1,180,000$ & $1,959,778$ \\
\hline 2013 & 20,000 & 42,495 & 499,485 & $1,342,000$ & $1,903,980$ \\
\hline 2014 & & 18,326 & 378,727 & $1,013,000$ & $1,410,053$ \\
\hline 2015 & & 53,286 & 359,171 & 888,000 & $1,300,457$ \\
\hline
\end{tabular}

Source: UN database, 6309, Export data.

Pakistan is one of the world largest importers of used textiles despite also being a country with a complete textiles value chain. Overall imports of used textiles are increasing on average at a rate of 11-12\% annually. The largest exporters to Pakistan are USA, UK, Germany, South Korea and Canada. Imports from Nordic countries for used textiles are small in comparison.

As identified in Phase 1 of the main report, of the 13 largest exporters of textiles from the Nordic countries, only two reports exporting directly to Pakistan in 2014; Myrorna/Fretex exported just over 1600 tonnes of pre-sorted textiles to Pakistan in 2014, via their export agency Fretex International. Pre-sorting comprises removal of the "cream" (top 10\% quality) for sale in Nordic countries and of textiles and nontextiles waste (see next section).

However, Nordic collected textiles also arrive in Pakistan via intermediate countries where they have been sent for detailed sorting. According to Phase 1 , this indirect flow represents around 3,400 tonnes a year. Thus, direct and indirect imports of used textiles from Nordic countries total around 5,000 tonnes a year. This is less than $1 \%$ of total imports of used textiles to the country.

In general, the used textiles exported directly or indirectly from the Nordic countries comprise textiles of insufficient quality for re-use in the Nordic countries. However, the direct exports by Fretex International may also include some excess unsold goods donated by brands with specific instructions not to resell in the Nordic countries.

Fretex International reports exporting around eight containers of pre-sorted used textiles each month to sorters in Pakistan totalling approximately 1,500-2,000 tons per year. This volume has been fairly consistent over the last five years. 


\section{Overview of process routes for textiles}

\section{Direct import from Nordics}

As noted in the previous section, our interviews indicate that there are two primary process routes for used textiles from the Nordic Countries to Pakistan. One exporter on behalf of two charitable collectors (Myrorna and Fretex) pre-sort the collected textiles in the Nordics before exporting the remainder directly to sorters in Pakistan.

Textiles which can be sold locally in the Nordic countries are removed from the textiles bundles prior to export. Dirty or wet clothes which have no value are also removed and sent to incineration in the Nordic countries. This constitutes only a small fraction of the textiles. Non-textile waste is also removed before export. These exports to Pakistan comprise around 1,60o tonnes.

\section{Indirect import from Nordics}

As also identified in the Phase 1 report, other organisations reported that textiles are being exported to interim countries for more detailed sorting, primarily located in Eastern Europe i.e. Poland and Bulgaria.

Here the textiles are divided into over one hundred fractions and grades depending on the quality and type of product. A part of this is sold in the sorting country, some is disposed of as waste or recycled and the rest is exported. The better grades are typically exported to Africa and the Middle East and the lower grades to Asia including Pakistan (see Appendix C).

Typically the exports to Pakistan arriving via interim countries are second grade textiles, such as worn out and miscoloured clothing. According to Fretex International the direct exports following pre-sorting in the Nordics may include better quality textiles including excess unsold clothing from retailers.

\section{Sorting}

According to several respondents, both the direct pre-sorted imports from the Nordic countries and the indirect sorted imports are sorted upon arrival at sorting plants. Several respondents mention that the quality of the textiles received from the Nordic countries is relatively high as compared to textiles received from other sources.

Some sorting companies are located within tax free zones - Export Processing Zones (EPZ) or Special Economic zones. It is not a demand form the Pakistan Gov- 
ernment that companies importing from the Nordics should be located within these zones, but there are incentives and facilities that could benefit the companies.

Our interviews indicate that the intention with EPZs is to support investment in the export-oriented industry and to increase exports from Pakistan. The companies within the zones are thus not intended to operate in the domestic market, for further information about the EPZ system see the section on Protection.

Fretex international mentions that as a general rule the textiles collected by Nordic organisations arriving in Pakistan have already been sorted with the intention that only reusable or reparable clothing is sent to the country from Europe. This is because organisations do not trust the waste management system in developing countries. However, there sometimes remain textiles in the second grade clothing that, under closer examination, are not fit for reuse.

The quality and destinations for Fretex International's sorting partner in an EPZ in Pakistan are given below.

Table 21: Destinations for various quality fractions following sorting by selected company in an Export Processing Zone

\begin{tabular}{|c|c|c|c|c|c|c|}
\hline \multirow[b]{2}{*}{ Fraction } & \multicolumn{3}{|c|}{ Reuse } & \multicolumn{2}{|r|}{ Recycling } & \multirow{2}{*}{$\begin{array}{l}\text { Waste } \\
\text { Incineration } \\
\text { /landfill }\end{array}$} \\
\hline & $\begin{array}{l}\text { Top quality } \\
\text { - exported } \\
\text { to Africa }\end{array}$ & $\begin{array}{l}\text { Shop quality } \\
\text { for domestic } \\
\text { reuse }\end{array}$ & $\begin{array}{l}\text { Low shop quali- } \\
\text { ty for domestic } \\
\text { reuse }\end{array}$ & $\begin{array}{l}\text { Recycling do- } \\
\text { mestic }\end{array}$ & $\begin{array}{l}\text { Exported for recycling ( me- } \\
\text { chanical recycling India and } \\
\text { wipes for industrialised coun- } \\
\text { tries) }\end{array}$ & \\
\hline & $40 \%$ & $1 \%$ & $1 \%$ & $21 \%$ & $36 \%$ & ०\% \\
\hline
\end{tabular}

As the importers pay for the textiles they have a strong economic incentive to use and reuse all materials. As a consequence waste from the plants is limited as any leftover textiles from the sorting plants are used in one way or the other, for example recycled into industrial wipes or for their fibres.

The Danish Embassy reported that companies in Pakistan buying from EU charities must normally live up to requirements concerning working conditions and occasionally also environment requirements. To which extend they do so, is however not clear and depends on their final market. Companies not trading with charities may not need to follow any strict rules as there are no set rules in the country for all companies to follow. 


\section{Reuse}

The business model of the receiving companies in Pakistan differs depending on whether they are receiving pre-sorted or more comprehensively sorted textiles.

The company that receives pre-sorted textiles directly from the Nordics for further sorting report that after sorting in Pakistan $40 \%$ of the textiles are re-exported to African wholesalers for reuse, who sell it on to smaller traders and eventually market sellers. The company lies in the special economic zone close to Karachi.

Regulations in the African countries limit i.e. the size of the bales to a maximum weight of $50 \mathrm{~kg}$. However, our respondent mentioned that when visiting markets in the recipient countries larger bales were observed, indicating that bribes and illegal trade occurs.

Other companies report that most of the textiles they receive are sold locally for reuse in Pakistan. This mostly applies to the textiles which have been sent to Pakistan following detailed sorting in Eastern Europe, since the textiles suitable for the African markets have already been filtered off (see Poland report) but it can also include imports direct from the Nordics.

Danish Enterprises estimate that around 90\% of what they receive is sold for reuse at local markets in Pakistan. This company is located outside the special economic zones since laws within Pakistan limit the amount of wearable clothing that can be exported from the EPZ zones into the main part of Pakistan as mentioned by Fretex International.

Historically, second hand textiles sold in Pakistan have mainly been sold in small towns and villages in the northern areas. The sale varies according to season and is highest in the winter season as temperatures can drop well below freezing. Our interviews also indicate, however, that in recent years new customers have emerged from big metropolitans cities such as Karachi and Lahore.

The price of second-hand textiles is set at the world market, and fluctuates across seasons, and as mentioned above, winter clothing is more valuable than summer clothing. As seen from Figure 3, the prices are currently at a low point and the world market prices have decreased in recent years. ${ }^{28}$ Furthermore, sources mention that it is currently difficult to obtain a good price at the African markets due to currency issues. This limits the amount of Nordic textiles that can be brought as these are in general more expensive than others. Our interview indicates that there is, however, still a demand for the Nordic textiles due to high quality.

\footnotetext{
${ }^{28}$ The prices are calculated based on UN data.
} 
Our interviews show a discrepancy between the prices paid as one reports the prices as USD $0.10 / \mathrm{kg}$ while the price is around USD $0.35 / \mathrm{kg}$ according to other sources. The difference in prices might reflex differences in the type and quality. This, as the higher prices is an overall price for all items imported under code 6309 and 6310.

Figure 31: Price levels of imported used textiles - current prices

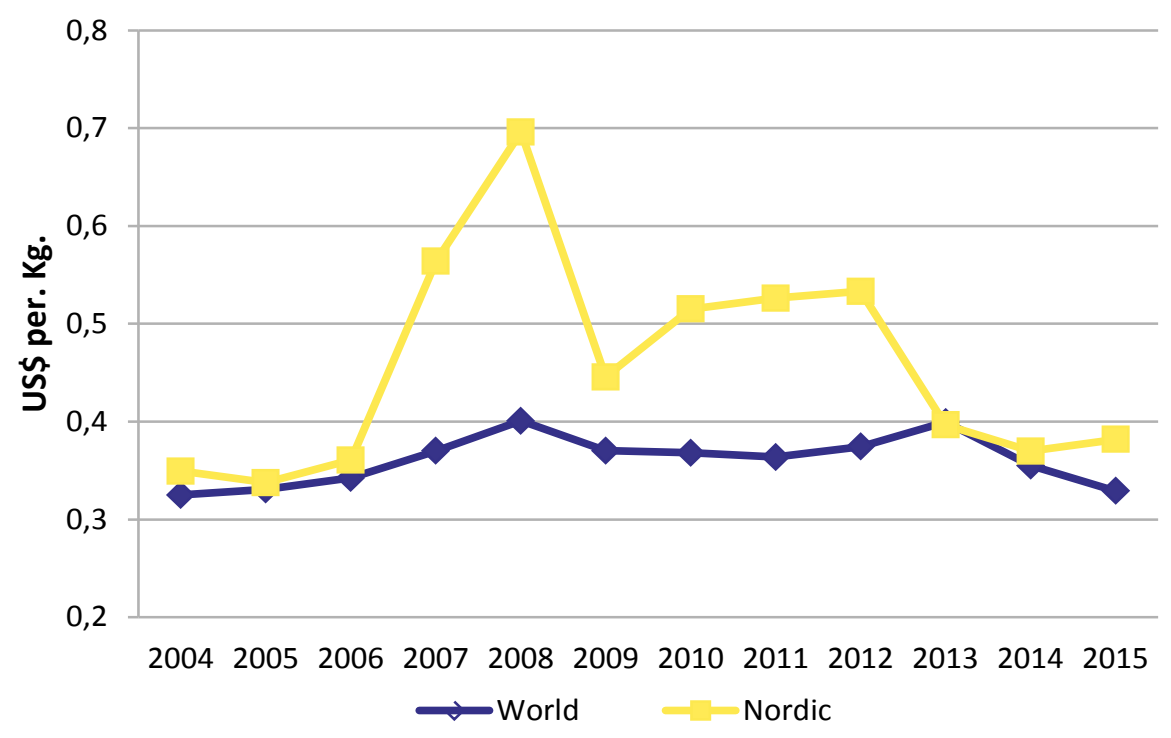

Source: UN-database and own calculations.

\section{Recycling}

As mentioned above all textiles sent to Pakistan are either pre-sorted or undergo more detailed sorting before arriving in the country with the intention that all textiles arriving in Pakistan are suitable for reuse or repair prior to reuse.

Still there could be textiles among the received that under closer examination are not fit for reuse, nor repair. The textiles are therefore again sorted upon arrival partly to weed out the textiles not fitted for used but also to divide the textiles into types, sizes etc.

Damaged textiles are often repaired before being sold. Leftover textiles from the plants and textiles that are not eligible for resale are recycled into industrial wipes and fibres. 
One respondent mentions that around 10\% of what they receive is made into wipes and fibres. This concern the pre-sorted textiles directly imported from the Nordic countries.

As reported earlier, around $20 \%$ of the pre-sorted textiles that Fretex International send to Pakistan for detailed sorting is recycled domestically. Most of this is made into materials, which can be reused in production of new textiles. Another approximately $36 \%$ of the exports are re-exported for recycling in Australia, New Zealand, India, England, Canada, United States and South Africa. The exports for all countries except India are cut into industrial wipers at the sorting plant in the EPZ, The textiles send for reuse in India are slashed into smaller fragments according to Indian law so that they can't be reused. These textiles are intended for mechanical unravelling to extract threads for use in textile products.

Note that while there are limits on the transit of reusable textiles from the EPZs to the rest of Pakistan, these limits don't apply to textiles intended for recycling.

\section{Waste}

Our interviews indicate that there is no thorough research on recycling activities in Pakistan but there are laws regarding environmental compliance and contamination. On top of this our study indicates that there are further initiatives within the tax free zones. Here, the wastes are auctioned away as most of it consists of reusable materials such as plastics and paper.

As none of the textiles are given as donations this creates economic incentives to limit the textile wastes. Fretex International reports that none of the pre-sorted textiles sent to Pakistan for sorting ends in incineration, landfill or any other form of waste treatment other than recycling.

Companies within the EPZ zones, whose operation results in the creation of harmful affluent that cause environmental pollution, are required to adopt such measures as are necessary for the proper treatment of the pollutants before they are disposed. However, generally rules e.g. regarding water management are limited but again some charities selling to Pakistan companies impose proper wastewater management and, therefore, they often have their own waterworks.

Wastewater is still a large problem in the county, yet, attention to the problem is increasing and there is a rising concern amongst the public. Interviews with exporters and importers indicate that water is not used in production and handling of second hand textiles and is thus not a problem in this part of the industry. 
According to the Environmental Ministry of Pakistan around 59000 tons of municipal solid waste generated per day (Pakistan Ministry of Finance, 2014). According to the World Bank (2010) less than $50 \%$ of municipal waste is collected; and even then it is disposed at dumpsites or roadsides since there are hardly any sanitary landfills in Pakistan. This is confirmed by a global waste management country needs assessment launched in 2010 by UNEP, which found that due to lack of any other solution, dumping by official collectors of waste on roadsides, canals, and low-lying land is common practice. ${ }^{29}$

Waste disposal practices by the population also need to be improved. There is little awareness of the health and environmental hazards generated by untreated or dumped household waste (UNEP, 2012).

There is an informal sector in Pakistan comprising small entrepreneurs buying wastes from households, and scavengers who sort through the waste dumped by the former two to find recyclable elements with a value. For example, UNEP (2015) reports that at Jam Chakro one of the largest dumpsites in the world, extending over 202 hectares is "served" by a scavenging community of more than 5,000 members. Children are often involved in waste picking with an estimated 20,000 working in Karachi alone (Zimring and Rathje, 2012).

Scavengers typically extract metal, plastics and glass (Zimring and Rathje, 2012), but are also reported as scavenging and processing electronics with considerable health risks (Zahidi, 2014). No reports were found of any focus on textiles in the activities of the informal sector. This may be because worn textiles are used by households as cloths and for other household uses until no more value can be obtained from them and they are dumped or burnt.

\section{Employment and output}

According to the World Bank the labour force consisted of around 65.4 million in 2014 . Our interviews with the Danish embassy in Pakistan indicate that the workforce is a little smaller, at 49 million. Of this the textile industry employs around $6 \%$ corresponding to around 3 million individuals.

Unfortunately there is no detailed mapping of employment in the used textile sector but the size of the sector is certainly relatively small compared to the size of the total textile industry. The value of the new textile export market from Pakistan lay at

\footnotetext{
${ }^{29}$ http://www.unep.org/gpwm/InformationPlatform/CountryNeedsAssessmentAnalysis/Pakistan/tabid/106536/Default.aspx
} 
USD 4.4 billion in 2014, 30 times larger than the USD 180 million for the value of the imports of used textiles in the same year (UN import export database).

The numbers of employees working in used textile sorting plants vary with size. Our interviews indicate that most of the employees work with sorting, cutting the clothing into rags or moving the clothing and bales around. At one plant, 20-30 out of 729 employees work in administrative or economic functions.

The plant management also reported that receiving approximately 8 containers with used textiles from the Nordics per month, or approximately 1,500-2,000 tonnes per year corresponding to $5 \%$ of the total amount received by the plant.

Assuming that there is no differences in the amount of work incurred by textiles received from the Nordic countries compared to textiles received from other sources it can be estimated that the import of Nordic textiles leads to the employment of approximately 36 full time staff. This corresponds to roughly 2 people per 100 tonnes/year, which is similar to that observed in Poland.

If this is scaled up to the full amount received directly and indirectly from Nordic countries, then we can estimate approximately 100 full time jobs in sorting in Pakistan as a result of Nordic textile imports.

In addition to this there will be many hundreds of families supported by the sale of Nordic origin second hand clothing in markets in Pakistan. No estimate could be obtained for this but the Malawian report estimated around six employees in sales for everyone in the sorting plants. If this is similar in Pakistan then the Nordic textiles may give a further 600 or more jobs in the country.

\section{Working conditions}

With respect to working conditions, one of our respondents stated that unions are not allowed within the EPZ. To accommodate workers, suggestion boxes have been put up at the plant where the employees can make anonymous suggestions for e.g. improvements. It is however not clear how much the box is used and due to cultural reasons it may not be used as much as the employees have a high degree of respect for their leaders and their cultural background makes it difficult for them to come forward with complaints and suggestions for improvements, generally since they are afraid of being fired. Further, some companies share information about the rights of the staff with the employees.

According to the Danish Embassy, there are no set rules for all companies to follow but companies doing business with charities in the EU, generally have requirements for e.g. minimum working conditions. As an example, one exporter from the 
Nordic countries with a code of conduct noted that the daily working hours at their buyers sorting plant are from 8.45-17.15, with two tea breaks. The workers also have a free lunch provided. All food and drinks are free during the workday. On top of this, each day they are being transported to the company via bus for free. The buses pick them up at specified locations in the city each day and bring them back after work. The Embassy however also mentions that it is a choice of the individual Pakistani companies to follow any of the compliances and which to follow will depend on their final export market.

Another source mentions that the imported textiles can be divided into two categories. The ones that are sold at the local market and the ones recycled. The working conditions for individuals handling second hand textiles depends on the category as the conditions for resellers may be better than those at recycling plants.

What the working conditions are like in the used textile sector not determined by codes of conduct is not known. Certainly in the regular textile industry exploitation in regard to wages, working hours and worker's rights are widespread.

Textile workers often have to do compulsory overtime and often get no permanent contracts even though they have been working in a factory for years. This leads to fear of losing jobs and makes exploitation and maltreatment easier for managers and factory owners. The right to form unions as well as the right to collective bargaining and the right to strike are often severely infringed by factory owners and by Pakistani police (Stotz, 2015).

Wages paid to workers within manufacturing are higher than those paid to labourers working within the agricultural sector (see also Table 3). However, they are amongst the lowest in the manufacturing sector (Stotz, 2015).

There are minimum wages set for the textiles sector which differ for different kinds of work, but it is not known whether or how these are set for the used textile industry. According to Stotz (2015), the minimum wage of around 10 ooo rupees (USD 100) per month is barely enough to purchase food providing recommended nutritional value.

There is also a large discrepancy between the salaries for male and females in almost all industries (Table 4). As the salaries refer to the manufacturing industry it is thus not limited to second hand textiles. Stotz (2015) notes widespread discrimination against female workers in many textile factories. 
Table 23: Average monthly wages of employees by major industry divisions, Rupees per month

\begin{tabular}{|c|c|c|c|c|c|c|}
\hline & \multicolumn{3}{|c|}{$2012-13$} & \multicolumn{3}{|c|}{$2013-14$} \\
\hline & Total & Male & Female & Total & Male & Female \\
\hline Total & 12,118 & 12,804 & 7,869 & 13,155 & 14,079 & 8,228 \\
\hline Agriculture, forestry, hunting and fishing & 6,211 & 7,873 & 3,863 & 6,327 & 7,995 & 4,236 \\
\hline Mining \& Quarrying & 15,508 & 15,740 & 5,169 & 17,971 & 17,971 & - \\
\hline Manufacturing & 11,023 & 11,734 & 4,958 & 11,720 & 12,716 & 4,953 \\
\hline Electricity, gas and water & 22,600 & 22,711 & 16,628 & 23,060 & 23,251 & 14,486 \\
\hline Construction & 9,614 & 9,610 & 10,455 & 11,008 & 11,031 & 8,563 \\
\hline Wholesale \& retail trade and restaurants \& hotels & 8,656 & 8,668 & 7,245 & 9,706 & 9,729 & 9,302 \\
\hline Transport, storage and communication & 13,792 & 13,733 & 20,152 & 14,950 & 14,972 & 20,517 \\
\hline Financing, insurance, real estate and business services & 28,658 & 28,673 & 28,624 & 35,194 & 35,280 & 31,182 \\
\hline Community, social and personal services & 16,642 & 17,902 & 12,189 & 18,932 & 20,758 & 13,508 \\
\hline
\end{tabular}

Source: Labour Force Survey, 2013-2014. Government of Pakistan, Statistics Division.

However, it should be noted that Fretex International mentions that used textile sorting in particular is skilled work, and many consider it is work that only women have a good enough eye and feel for. It could mean that sorters are paid higher than average wages in order to keep them once they have been trained.

In the broader industry, concerning the production of new textiles, there are many aspects that could be improved such as safety measures and rights of the workers to form trade unions. This is not the findings in our interviews however the problems might still be a concern in the overall second-hand industry.

\section{Codes of conduct and social programmes}

Our research indicate that local companies dealing with European organisations are often required to follow certain standards and compliance related to environment, labour laws, CSR etc. It is however not clear how many of the Pakistani companies follow such standards unless required by sellers Codes of Conduct.

As mentioned some cases the companies in Pakistan are not the final destination for the textiles and tracing and ensuring proper conditions at the final destination is more difficult especially as the buyers get smaller and more diffuse e.g. small buyers in Africa. Our interviews indicate that working conditions have improved over the years but there is still room for improvement.

Fretex international, who sells all the excess good which Myrorna and Fretex can not sell in the Nordic stores, imposes a Code of Conduct to all buyers of these goods, which they enforce as far as they can further downstream from the first buyer. To en- 
sure that the requirements are met Fretex International seeks to audit all partners at least once a year.

The $\mathrm{CoC}$ defines a minimum standard that all clients are expected to follow. These are based on established international agreements. The clients must follow national laws but if and issue is addressed both by the national law and the $\mathrm{CoC}$ the more stringent rule should be applied.

The $\mathrm{CoC}$ contains rules on working conditions including a ban on the use of child labour, discrimination and forced labour; environment including waste management; sound business and transparency meaning that bribes and corruption is not accepted; and transport of goods urging the client to consider the environmental impacts of transport of used goods.

We have not been able to assess whether $\mathrm{CoC}$ is a widespread phenomenon but our interviews indicated that is used by companies trading with Nordic countries.

We have not been able to assess how much and if any of the textiles imported from Nordic countries are given away as donations but according to one exporter none of the textiles are given as donations. A reason for this is that paying for the textiles creates incentive to limit the waste and thus find other use for it.

\section{The new textile industry in Pakistan}

Pakistan is the 8th largest exporter of textile products in Asia. Textiles is the most important manufacturing sector of Pakistan and has the longest production chain, with inherent potential for value addition at each stage of processing, from cotton to ginning, spinning, fabric, processing, made-ups and garments (Pakistan Ministry of Textile Industry, 2015).

This sector contributes nearly one-fourth of industrial value-added, provides employment to about $38 \%$ of the manufacturing labour force (Clean Clothing Campaign, 2015), and accounts for around 10\% of GDP. It provides employment to about 3 million people or roughly $6 \%$ of the 49 million workforce of the country. Barring seasonal and cyclical fluctuations, textile products have maintained an average share of about $60 \%$ in national exports (Pakistan Ministry of Textile Industry, 2015).

According to the Danish Embassy the textiles sector of Pakistan is an exportoriented sector and around $70 \%$ of its production is for the export market. Annual textiles exports are valued at approximately EUR 14 billion. Textiles make up $60 \%$ of the country's total exports by value. Garment exports comprise $8 \%$ of Pakistan's GDP (Stotz, 2015). 
According to the Ministry of Textile Industry the manufacturing sector has had a positive and fairly constant growth rate since $2009 .^{30}$

Prices are currently at a low point and the world market prices for textiles have decreased in recent years. A combination of many explanatory variables are likely to effect the textile industry i.e. increase in cost of production as energy prices rises, depreciation of the rupee and high inflation. As seen from figure 5 , inflation has been declining since 2010 while the rupee has depreciated. In 2014, inflation stood at $7.2 \%$ with a significant drop to $2.5 \%$ in 2015 .

Table 24: Inflation and exchange rates

\begin{tabular}{rrrr} 
Inflation, consumer prices (annual \%) & \multicolumn{2}{c}{$\begin{array}{c}\text { Official exchange rate (Rupee per USD, } \\
\text { period average) }\end{array}$} \\
& Pakistan & United States \\
2004 & & & 58 \\
2005 & 7.4 & 2.7 & 60 \\
2006 & 9.1 & 3.4 & 60 \\
2007 & 7.9 & 3.2 & 61 \\
2008 & 7.6 & 2.9 & 70 \\
2009 & 20.3 & 3.8 & 82 \\
2010 & 13.6 & -0.4 & 85 \\
2011 & 13.9 & 1.6 & 86 \\
2012 & 11.9 & 3.2 & 93 \\
2013 & 9.7 & 2.1 & 102 \\
2014 & 7.7 & 1.5 & 101 \\
2015 & 7.2 & 1.6 & \\
\hline
\end{tabular}

Source: World bank database.

Even through the import prices have declined as indicated by the UN data, interviews indicate that the retail price have increased by $20-30 \%$ in items like clothes, jacket, children garments, shoes, pant etc. this due to increased taxes and duties and devaluation of the rupee against the dollar.

\footnotetext{
${ }^{30}$ Pakistan Economic Survey 2014-2015, Statistical Appendix, Table 1.
} 
Figure 32: Inflation rates

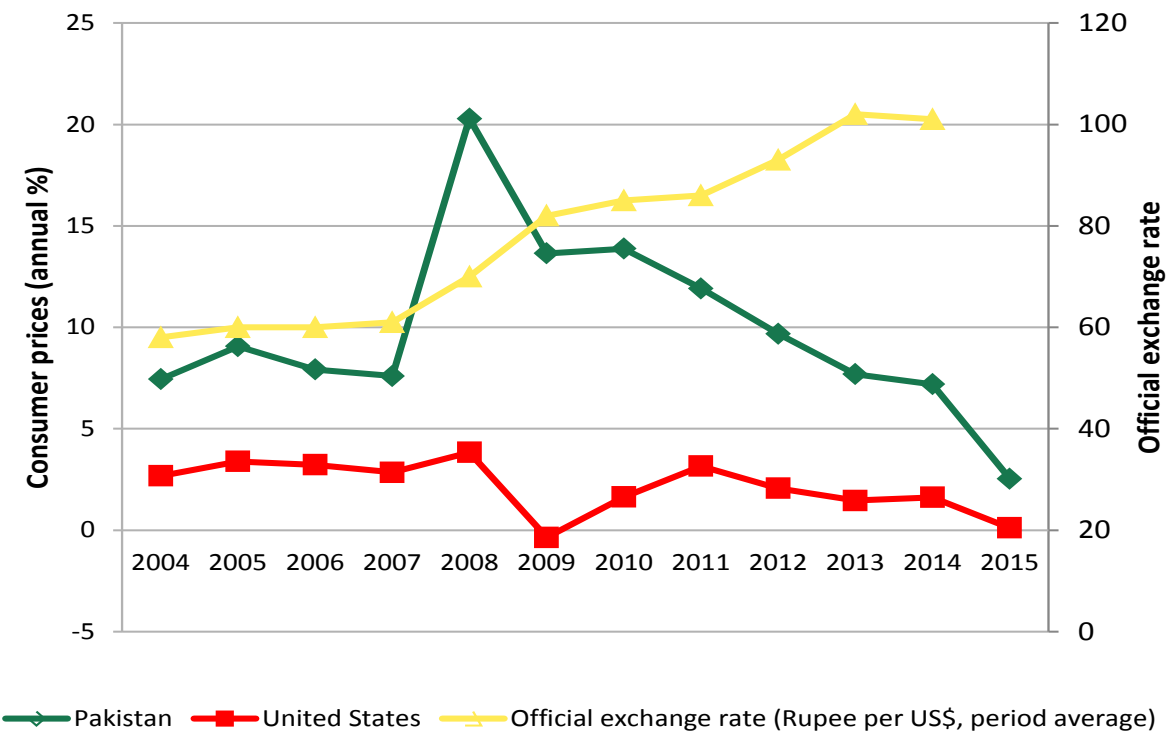

Source: World Bank.

The amount of second hand textiles imported from all over the world has certainly increased in recent years this even through the rupee has depreciate making the textiles more expensive. This could indicate that more new, low and middle-income individuals who can't afford the price of new textiles are beginning to buy second-hand.

Another reason for the increase in imports of used good to Pakistan suggested by interviewees could be increased imports to Afghanistan, which has no seaport and some goods delivered to Pakistan are thus re-exported or smuggled to Afghanistan. Finally, a large part of the imports are coming to Pakistan for sorting before being exported again for reuse elsewhere. This part of the imported second-hand is thus not intended for resale in the country.

Moreover, $70 \%$ of the new textiles and clothing production in Pakistan is for the export market to e.g. EU and USA and therefore will remain largely unaffected by reused textiles sold at local markets.

Second-hand is more likely to compete with imported new clothing. One respondent noted that due to a poorly integrated taxation system in Pakistan, the price of imported new clothing is relatively high compared to other countries. Thus the imports of reused textiles and clothing might provide a benefit for the poor who can buy used jackets and other clothing in a quality that wouldn't otherwise have been possible. 
A key piece of evidence for the lack of impact on the Pakistan textile industry is that growth in textile manufacturing has stayed positive since 2009 despite increases the imports of second hand.

Nevertheless, there is some concern that around 3-4 kg per capita is being imported to Pakistan for reuse. According to our contact in the Ministry of Textiles this may amount to $50 \%$ of the domestic demands for clothing and thus may be impacting the viability of local small and medium enterprises.

This issue was first raised by the textile associations in the last year. As a consequence, the customs department has now begun monitoring the imports of these items.

\section{Protection}

According to the European Commission's Market Access Database there are no trade restrictions on worn clothing and other worn textiles into Pakistan from the rest of the world. ${ }^{31}$ Pakistan is listed as one of the Most Favoured Nations under the WTO. Customs add a duty of $5 \%$ to imports of used clothing and an advance withholding tax at a rate of $5.5 \%$ of the dutiable value. For commercial importers the advance tax is set at $3 \%$ while for importing individuals the advanced tax is at $6 \% .^{32}$ According to our interviews the duties and taxes on worn clothing and other worn articles sums up to $18.5 \%$.

The Government of Pakistan established Export Processing Zones Authority (EPZA) in 1980 with the mandate to plan, develop, manage and operate EPZs in Pakistan. EPZA undertook an extensive industrial program for setting up a chain of Export Processing Zones in Pakistan. These EPZs are set up in close cooperation or under joint venture arrangement with Private Sector/Provincial Governments. Some of the first zones to be established were: Karachi Export Processing Zones (KEPZ) and AlTuwairqi Steel at Karachi, Sialkot EPZ, Gujranwala EPZ in Punjab, Risalpur EPZ at NWFP, Saindak, Reko Dek, Duddar and Gwadar EPZ in Baluchistan.

As the intention with the tax free zones was to support investment in the export oriented industry and to increase exports from Pakistan and that the companies within the zones are thus not meant to operate in the domestic market there is a restriction of flows of imported reusable textiles from the EPZs into the rest of Pakistan. Accord-

\footnotetext{
${ }^{31}$ http://madb.europa.eu/madb/indexPubli.htm

${ }^{32}$ http://madb.europa.eu/madb/atDutyDetailPubli.htm?datasetid=MAAT-PK16

o3voo1\&hscode=6309\&countries=PK\&datacat_id=AT\&keyword=\&submit=\&pathtoimage=http://madb.europa.eu/at/imag es/\&showall=F\#
} 
ing to Fretex International, up to $15 \%$ of production volume in EPZs may be transferred out of the EPZ into the main part of Pakistan for sale there. Therefore approximately $20 \%$ of the reusable textile output of sorting plants in EPZs can be "imported" into the rest of the country. The remainder must be re-exported out of the country.

On the other hand importers of used textiles are not forced to be located in the $E P Z$, rather there are certain incentives to be located there. In general companies, which use the country as an interim station for sorting before exporting the sorted grades elsewhere, could benefit from being located in the EPZ, while companies which import for sale in Pakistan will locate outside of it.

Fretex International mentions that there are no restrictions on flows of leftover textiles intended for recycling into fibres from the EPZ into the remainder of the country, which means that Pakistan industry can make use of the waste that emerges from the sorting process before textiles are exported for reuse elsewhere.

\section{References}

Stotz, L. (2015) Pakistan Country Report An overview of the garment and textile industry in Pakistan. Report for the Clean Clothing Campaign.

https://cleanclothes.org/resources/publications/factsheets/pakistan-country-report-22015.pdf

Pakistan Ministry of Finance (2014) Economic Survey 2013-2014: Chapter 14 Environment. http://finance.gov.pk/survey/chapters_14/16_Environment.pdf

Pakistan Ministry of Textile Industry (2015) Textile Policy 2014-19.

http://202.83.164.29/moti/userfiles1/file/Textile\%2oPolicy\%202014-19.pdf

UNEP (2012) Needs Assessment on Capacity Building in Waste Management: Narrative Analysis Report. Report for Global Partnership on Waste Management (GPWM). http://www.unep.org/gpwm/Portals/24123/images/Needs\%20assessment/Needs\%20Assessm ent\%2onarrative\%2oanalysis.pdf

World Bank (2010) Establishing integrated solid waste management in the large cities of Pakistan Multan : comprehensive scope evaluation report. Washington, DC: World Bank. http://documents.worldbank.org/curated/en/958641468144569940/Establishing-integratedsolid-waste-management-in-the-large-cities-of-Pakistan-Multan-comprehensive-scopeevaluation-report

UNEP (2015) Global Waste Management Outlook. Report from UNEP and ISWA. https://issuu.com/raquel.lejtreger/docs/global_waste_management_outlook-20/29

Zahidi, F. (2014) Worries pile up as waste grows in Pakistan. Online article in Al Jazeera, 11th August, 2014. http://www.aljazeera.com/indepth/features/2014/08/solid-waste-pakistankarachi-2014867512833362.html

Zimring, C.A. \& Rathje, W.L. (2012) Encyclopedia of Consumption and Waste: The Social Science of Garbage. Sage Publishing. https://uk.sagepub.com/en-gb/eur/encyclopedia-ofconsumption-and-waste/book235186\#description 
Nordic Council of Ministers

Ved Stranden 18

DK-1061 Copenhagen $\mathrm{K}$

www.norden.org

\section{Exports of Nordic Used Textiles}

The Nordic Council of Ministers' Green Growth Initiative highlighted the need for comprehensive collection, reuse and recycling of used textiles as part of a circular economy.

Over 100000 tonnes of used textiles are already collected each year in Nordic countries. This is for the most part carried out by charities to fund their charitable activities. Around three quarters of these textiles are sold on global markets.

Does the export of used textiles support the circular economy through reuse and recycling, or are we simply exporting waste to countries that don't have the facilities to deal with it? And does the export have a negative effect on textile industries in receiving countries?

This report answers these questions by tracking flows of exports to their final destinations, and by estimating the socio-economic and environmental impacts arising from their subsequent treatment.

TemaNord 2016:558

ISBN 978-92-893-4769-3 (PRINT)

ISBN 978-92-893-4770-9 (PDF)

ISBN 978-92-893-4771-6 (EPUB)

ISSN 0908-6692

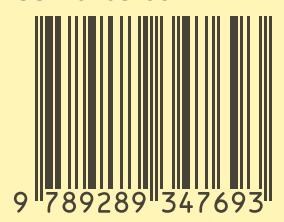

